\title{
PRESENTASI ORAL
}

FERTILITAS

ENDOKRINOLOGI REPRODUKSI

\section{FAKTOR RISIKO REKURENSI ADENOMIOSIS BERDASARKAN SKOR VAS PADA PASIEN YANG TELAH DILAKUKAN OPERASI DI RUMAH SAKIT HASAN SADIKIN PERIODE TAHUN 2015 - 2017}

Dewi AK, Ritonga MA, Purwara BH, Kurniadi A.

\section{Departemen Obstetri dan Ginekologi Fakultas Kedokteran Universitas Padjadjaran/ RSUP Dr. Hasan Sadikin Bandung}

Latar Belakang: Adenomiosis merupakan kondisi ginekologi yang sering terjadi pada wanita di semua usia. Adenomiosis adalah suatu keadaan yang ditandai dengan adanya endometrium dan stroma di dalam miometrium, dikelilingi oleh otot halus yang hiperplasia. Manifestasi adenomiosis adalah dismenorea, menoragia, dan nyeri pelvis yang kronik namun tidak terdiagnosis. Penatalaksanaan adenomiosis digunakan untuk mengatasi gejala, salah satunya nyeri. Nyeri pada setiap pasien bervariasi, dipengaruhi oleh faktor-faktor risiko yang dimiliki, sehingga perlu adanya penelitian untuk mengetahui hubungan antara faktor risiko dengan rekurensi nyeri berdasarkan skor VAS pada pasien adenomiosis.

Tujuan: Tujuan penelitian ini adalah untuk menganalisis faktor risiko rekurensi adenomiosis berdasarkan skor VAS pada pasien yang telah dilakukan operasi di Rumah Sakit Hasan Sadikin pada periode tahun 2015 - 2017.

Metode: Penelitian ini merupakan studi observasional dengan rancangan case-control. Subjek penelitian ini adalah seluruh pasien penderita adenomiosis yang dilakukan wawancara dan pengukuran skor VAS yang telah dilakukan operasi di Rumah Sakit Hasan Sadikin pada periode tahun 2015 2017. Populasi kasus adalah 101 orang dan didapatkan 31 kasus yang memenuhi

kriteria inklusi dan eksklusi. Maka didapatkan 31 sampel sebagai kasus dan 31 sampel sebagai kontrol. Untuk analisis data numerik diuji dengan menggunakan uji Mann Whitney. Untuk analisis pada data kategorik diuji dengan menggunakan uji statistika Chi Square.
Hasil: Hasil uji statistika faktor risiko pasien penderita adenomiosis berdasarkan skor VAS yang dilakukan operasi di Rumah Sakit Hasan Sadikin pada periode tahun 2015 - 2017 menunjukkan nilai $\mathrm{P}$ pada variabel frekuensi menikah dan menarche lebih besar dari 0.05 (nilai $\mathrm{P}>0.05$ ) yang berarti tidak signifikan atau tidak bermakna secara statistik pada kelompok pasien kasus dan kontrol, sedangkan nilai $\mathrm{P}$ pada variabel usia, paritas, dan usia anak terkecil lebih kecil dari 0.05 (nilai $\mathrm{P}<0.05$ ). Hasil uji statistika pada kelompok penelitian diperoleh nilai $\mathrm{P}$ pada variabel skor VAS kelompok kasus dan kontrol lebih kecil dari 0.05 (nilai $\mathrm{P}<0.05$ ) yang berarti terdapat perbedaan rerata yang signifikan secara statistik antara variabel skor VAS Pre dan Post pada kelompok pasien kasus dan kontrol.

Kesimpulan: Rekurensi adenomiosis berhubungan dengan skor VAS yang dipengaruhi faktor risiko diantaranya usia, paritas dan usia anak terkecil.

Kata Kunci: Rekurensi adenomiosis; faktor risiko; skor VAS

\section{METODE SIMPAN BEKU OVARIUM SEBAGAI UPAYA PRESERVASI FUNGSI REPRODUKSI}

Budi Wiweko ${ }^{1,2,3}$, Sarah Chairani Zakirah ${ }^{1,3^{*}}$, Aida Riyanti $^{1,3}$, Mila Maidarti ${ }^{1,3}$, Eliza Mansyur ${ }^{3}$, Tita Yuningsih $^{3}$, Aulia Ahmad ${ }^{4}$, Arief Boediono ${ }^{5}$, Soegiharto Soebijanto $^{1,3}$, Biran Affandi ${ }^{3}$

${ }^{1}$ Divisi Fertilitas Endokrinologi dan Reproduksi, Departemen Obstetri and Ginekologi, Fakultas Kedokteran, Universitas Indonesia, Jakarta, 10430, Indonesia, ${ }^{2}$ Klinik Yasmin IVF, RSUP Dr. Cipto Mangunkusumo, Jakarta, 10430, Indonesia, ${ }^{3}$ Klaster Human Reproductive, Infertility and Family Planning Research Center, Indonesia Medical Education and Research Institute(IMERI), Fakultas Kedokteran, Universitas Indonesia, Jakarta, 10430, Indonesia, ${ }^{4}$ Departemen Histologi, Fakultas Kedokteran Universitas Indonesia, Jakarta, 10430, Indonesia, ${ }^{5}$ Departemen Anatomi and Fisiologi, Institut Pertanian Bogor, Bogor, Indonesia

*Korespondensi: sarahchairani@gmail.com 
Tujuan: Usia harapan hidup dan 5-year survival rate pasien dengan radioterapi dan kemoterapi semakin meningkat. Tetapi, banyak pasien yang menjalani pengobatan kanker mengalami depresi akibat efek sampingnya. Para pakar telah berupaya untuk preservasi fungsi reproduksi. Kriopreservasi jaringan gonad, misalnya oosit, embrio, dan ovarium meningkatkan ekspektasi pasien untuk mendapatkan anak. Artikel ini bertujuan untuk menilai efek dari metode simpan beku ovarium terhadap jumlah dan morfologi folikel.

Metode: Metode simpan beku ovarium dilakukan sebagai upaya preservasi fungsi ovarium. Penelitian dilakukan dengan mengumpulkan ovarium dari 10 wanita usia 28-40 tahun yang menjalani operasi akibat tumor jinak ovarium. Analisis 167 folikel yang di warnai dengan hematoksilin-eosin dilakukan dibawah mikroskop. Kualitas folikel diamati berdasarkan intergritas morfologi jaringan, misalnya oosit, sel granulosa, dan mebrana basalis. Penelitian dilaukan menggunakan T-test untuk data yang berdistribusi normal dan Mann-Whitney untuk data yang tidak berdistribusi normal. Chi-Square dan Fisher's exact juga digunakan untuk mendapatkan proporsi.

Hasil: Hasil analisis menunjukkan bahwa jumlah folikel di ovarium mempunyai hubungan yang tidak signifikan dengan metode simpan beku ovarium. Morfologi sel granulosa, stroma, dan kolagen, sebelum dan setelah simpan beku juga mempunyai hubungan yang tidak signifikan dengan metode simpan beku ovarium ( $p>0.05)$. Hal ini dapat disebabkan karena kurangnya jumlah responden dalam penelitian. Tetapi, terdapat hubungan yang signifikan antara usia dan jumlah folikel $(\mathrm{p}<0.012)$. terdapat kecenderungan penurunan jumlah folikel seiring dengan peningkatan usia.

Kesimpulan: Metode simpan beku ovarium dapat digunakan sebagai pilihan utama pada wanita dengan risiko tinggi penurunan fungsi ovarium karena manfaat potensialnya.

Kata Kunci: Kriopreservasi, Fungsi Reproduksi, Simpan Beku Ovarium

\section{PERBANDINGAN KADAR TESTOSTERON DAN LEMAK VISERAL PASIEN SINDROM OVARIUM POLIKISTIK DI POLIKLINIK ASTER RSUP DR. HASAN SADIKIN BANDUNG SEBELUM DAN SETELAH PEMBERIAN TERAPI METFORMIN}

Imelda R.Siagian, Mulyanusa Amarullah Ritonga, M. Rizkar.A.S, Maringan DLT

Departemen Obstetri \& Ginekologi FK-UNPAD/RSUP Dr. Hasan Sadikin Bandung
Latar belakang: Sindrom ovarium polikistik adalah kelainan endokrin yang sangat umum terjadi pada wanita dalam masa reproduksi. sindrom ini paling banyak diperdebatkan dan menimbulkan pendapatpendapat yang kontroversial dalam bidang ginekologi endokrinologi dan reproduksi. Terdapat 50-70\% kasus sindrom ovarium polikistik yang berkaitan dengan adanya resistensi insulin. Peran agen sensitisasi insulin seperti metformin diharapkan dapat memperbaiki kondisi lemak dan testosteron bebas yang tinggi sehingga memperbaiki gejala klinis pasien dengan sindrom ovarium polikistik. Namun beberapa pengamat gagal menjelaskan perubahan biokimia yang disebabkan oleh metformin.

Tujuan: Penelitian ini bertujuan mengetahui perbedaan kadar testosteron dan lemak viseral pasien sindrom ovarium polikistik sebelum dan sesudah diberi pengobatan metformin.

Metode: Populasi penelitian didapatkan dari data penelitian DLBS 3233 yaitu 29 kasus wanita sindrom ovarium polikistik yang datang untuk berobat di Klinik Aster RSUP Dr. Hasan Sadikin Bandung periode Januari 2013 - Desember 2017, dengan menggunakan metode experimental design dengan pendekatan one group pretest-posttest design. Pengambilan sampel penelitian dilakukan secara purposing sampling yang diambil secara retrospektif pada data sekunder yang terdapat dalam rekam medik.

Hasil: Didapatkan rata-rata kadar testosteron bebas sebelum pemberian terapi metformin 5.68 \pm 5.385 dan sesudah pemberian terapi 4.02 \pm 5.060 . Rata-rata kadar lemak visceral sebelum pemberian terapi metformin $10.27 \pm 2.589$ dan sesudah pemberian terapi $8.00 \pm 1.488$. Sehingga disimpulkan terdapat perbedaan signifikan kadar testosteron (p:0.035) dan lemak visceral ( $\mathrm{p}: 0,0001)$ pada pasien sindrom ovarium polikistik sebelum dan sesudah pemberian terapi metformin.

Kata kunci: Sindrom ovarium polikistik ; Metformin ; Viseral fat

\section{KORELASI LEUKOTRIEN TERHADAP DENSITAS MASSA TULANG PADA WANITA MENOPAUSE}

Irwansyah Putra

Divisi Fertilitas Endokrinologi Reproduksi

Departemen Obstetri dan Ginekologi

Fakultas Kedokteran Universitas Sumatera Utara

Tujuan: Untuk mengetahui korelasi nilai leukotrien dengan densitas tulang pada wanita menopause. 
Metode: Penelitian ini merupakan penelitian deskriptif dengan pendekatan case Penelitian ini dilakukan di SMF Obstetri dan Ginekologi RSUP H. Adam Malik, Departemen Obstetri dan Ginekologi FK USU dilakanakan Desember 2018 sampai Februari 2019. Sampel yang memenuhi kriteria inklusi dan eksklusi kemudian diambil darahnya dan diperiksa kadar Leukotrien serum kemudian dilakukan pemeriksaan Bone Mass Density (BMD). Lalu dilakukan analisa korelasi secara statistik untuk menilai hubungan kadar leukotrien dan Bone Mass Density wanita Menopause.

Hasil: Sebagian besar subjek penelitian tergolong dalam klasifikasi osteopenia yaitu sebanyak 23 orang (76.7\%), pada penelitian ini juga terdapat $2(6.7 \%)$ subjek yang mengalami osteoporosis dan sisanya dalam keadaan normal sebanyak 5 orang (16.7\%).

Kesimpulan: Penelitian ini menyimpulkan adanya korelasi yang signifikan antara kadar leukotrien dengan densitas massa tulang $(r=-0,533 ; \mathrm{p}=0.020)$ dengan korelasi dengan $r$ hitung untuk densitas massa tulang lebih besar dari $r$ tabel dan bernilai negatif.

Kata Kunci: Menopause, Leukotrien, Bone Mass Density

\section{PERBANDINGAN TINGKAT KEBERHASILAN PREPARASI SPERMA METODE SWIM UP DENGAN DENSITAS GRADIEN PADA INSEMINASI INTRAUTERIN}

Irwansyah Putra

\section{Departemen Obstetri dan Ginekologi Divisi Fertilitas Endokrinologi Reproduksi Fakultas Kedokteran Universitas Sumatera Utara Medan, Indonesia}

Tujuan: Untuk mengetahui tingkat keberhasilan preparasi sperma metode swim-up dengan densitas gradien pada inseminasi intrauterin.

Metode: Penelitian analitik komparatif dilakukan di Klinik Fertilitas Halim, Rumah Sakit Ibu dan Anak Stella Maris Medan, Divisi Fertilitas Endokrinologi, dan Reproduksi Fakultas Kedokteran Universitas Sumatera Utara. Sebanyak delapan puluh pasangan infertil dibagi secara acak ke dalam dua kelompok berdasarkan metode preparasi sperma yang digunakan pada IUI yaitu swim up atau densitas gradien. Dilakukan evaluasi terhadap progresifitas sperma, total sperma motil, kehamilan biokimiawi dan kehamilan klinis.

Hasil: Rerata peningkatan persentase sperma progresif cepat dijumpai lebih tinggi secara signifikan $(\mathrm{p}<0,05)$ pada kelompok densitas gradien dibandingkan kelompok swim up $(19,02 \pm 16,19$ dan 11,78 $\pm 13,71)$. Rerata peningkatan persentase total sperma motil lebih baik pada kelompok densitas gradien dibandingkan kelompok swim up $(2,53 \pm 1,41$ dan 2,39 $\pm 1,06)$ namun tidak signifikan $(p>0,05)$. Kehamilan biokimiawi dan kehamilan klinis lebih tinggi pada kelompok densitas gradien (27,5\% dan 22,5\%) dibandingkan kelompok swim up (25\% dan 17,5\%) namun tidak signifikan ( $\mathrm{p}>0,05)$.

Simpulan: Preparasi sperma dengan metode densitas gradien memberikan hasil yang lebih baik dari segi peningkatan sperma progresif cepat, namun tidak ditemukan perbedaan signifikan pada kehamilan biokimia dan kehamilan klinis antara kedua kelompok metode preparasi sperma.

Kata kunci: Inseminasi intra-uterin, preparasi sperma, swim up, densitas gradien

\section{OVARIAL ENDOMETRIOSIS PADA WANITA PASCA MENOPAUSE}

Setiaji J, Mamengko L, Laihad BJ

\section{Department of Obstetrics and Gynecology, Faculty of Medicine University of Sam Ratulangi}

Latar Belakang: Endometriosis adalah kelainan ginekologi jinak, estrogen dependent dengan gejala nyeri panggul dan infertilitas. Endometriosis dikaitkan dengan siklus menstruasi, 2\% hingga 5\% wanita pascamenopause mengalami endometriosis. Endometriosis pasca menopause merupakan penyakit yang jarang terjadi. Estrogen dependent dianggap penting pada proses patofisiologis. Endometriosis dapat berkembang pada wanita menopause yang menjalani terapi sulih hormon atau karena faktor lain, dan dapat disebabkan oleh estrogen eksogen atau mungkin independen. Meskipun ada beberapa laporan yang sukses dengan perawatan seperti aromatase inhibitor, pembedahan harus dilakukan sebagai langkah pertama dalam pengelolaan ovarium pascamenopause endometriosis.

Laporan Kasus: Wanita 69 tahun P0A0 mengeluh nyeri pada perut bagian bawah hilang timbul dan terdapat benjolan pada perut. Pasien menarche umur 15 tahun, nyeri saat haid dirasakan sejak awal haid, riwayat haid teratur dan menopause saat umur 51 tahun. Tidak ada riwayat penggunaan kontrasepsi. Pemeriksaan fisik didapatkan berat badan $65 \mathrm{~kg}$, tinggi badan $146 \mathrm{~cm}$ (BMI:30,5). Pemeriksaan abdomen tampak cembung dan teraba massa kistik setinggi 2 jari di bawah umbilikus. Pemeriksaan ginekologi adneksa sebelah kiri teraba massa kistik berukuran sebesar bola voli. Pemeriksaan laboratorium darah lengkap normal, Ca- 
$12514,80 \mathrm{u} / \mathrm{ml}$. Pemeriksaan ultrasonografi tampak gambaran massa kistik berasal dari adneksa ukuran 12,3 $\mathrm{cm} \times 8,06 \mathrm{~cm}$ x $11,1 \mathrm{~cm}$ dan CT-Scan abdomen-pelvik didapatkan kista multiloculated septa tipis dengan eggshell calcification ovarium kesan benigna ukuran $11,81 \mathrm{~cm}$ x $11,50 \mathrm{~cm}$ x 9,60 cm. Dilakukan laparotomi potong beku hasil patologi anatomi kista endometriosis ovarii.

Kesimpulan: Mekanisme terjadinya endometriosis pascamenopause masih belum jelas, kemungkinan terdapat produksi estrogen oleh lesi endometriotik itu sendiri ataupun faktor lain. Wanita dengan endometriosis pasca menopause memiliki risiko transformasi ganas lebih tinggi. Manajemen bedah direkomendasikan sebagai lini pertama pada wanita pasca menopause dengan endometriosis.

Kata Kunci: Endometriosis, pasca menopause, kista

\section{UJI KLINIK TERKONTROL TERBUKA PERBANDINGAN EFFICACY, SAFETY DAN ACCEPTABILITY ANTARA SUNTIKAN KB, ESTRADIOL SIPIONAT 7,5 MGRAM DENGAN MPA 25 MGRAM (GESTIN F2 ${ }^{(R}$ DAN ESTRADIOL SIPIONAT (ES) 5 MGRAM (CYCLOFEM ${ }^{(R))}$}

Muhar Yunan Tanjung ${ }^{1}$,Delfi Lutan ${ }^{1}$, Ichwanul Adenin ${ }^{1}$, Herri S Sastramihardja ${ }^{2}$, Kuswinarti ${ }^{2}$, Taufiqurrahman Rahim $^{3}$, Mira Yustiawati ${ }^{3}$, Maftachah Rochmanti ${ }^{4}$, Ashon Sa'adi ${ }^{4}$, Retno Budiarti Farid ${ }^{5}$, Monica Fitria Farid $^{5}$

${ }^{I}$ Departemen Obstetri dan Ginecologi. Fakultas Kedokteran, Universitas Sumatera Utara, Medan. ${ }^{2}$ Departemen Farmakologi dan Therapi. Fakulas Kedokteran, Universitas Padjadjaran, Bandung. ${ }^{3}$ Departemen Obstetri dan Ginecologi. Fakulas Kedokteran, Universitas Lampung, Lampung. ${ }^{4}$ Departemen Farmakologi. Fakultas Kedokteran, Universitas Airlangga, Surabaya. ${ }^{5}$ Departemen Obstetri dan Ginecologi. Fakultas Kedokteran, Universitas Hasanudin, Makassar

Tujuan: Untuk mengetahui efficacy, safety and acceptability dari kontrasepsi suntikan dengan menggunakan estradiol sipionat 7,5 mg (Gestin F2 ${ }^{(\mathrm{R})}$ ) dan kontrasepsi suntikan MPA $25 \mathrm{mg}$ dengan estradiol sipionat (ES) $5 \mathrm{mg}\left(\right.$ Cyclofem $\left.^{(\mathrm{R})}\right)$. Hasil utamanya mengetahui kepuasan peserta..

Metode: 22 bulan Phase III penelitian, yang dilakukan pada multisenter penelitian pada 5 senters dengan 359 and 360, total 719 subjek pada masa penelitian 24 bulan. Wanita ingin menunda atau menjarangkan kelahiran di lokasi penelitian, 18-40 tahun, dengan siklus menstruasi yang normal (21-35 hari), menginginkan kontrasepsi Gestin F2 atau Cyclofem OC. Diikuti keluhan, flour albus, sakit kepada sakit dada, perdarahan pervaginam tak teratur dan perubahan berat badan. Serta alasan penghentian pemakaian kontrasepsi. Penelitian adalah Random Uji Klini terkontrol label yang terbuka permuted block randomization method dari kelompok yang menerima injeksi Gestin F2 dibandingkan dengan injeksi Cyclofem. Data dianalisa dengan metoda statistik.

Hasil: Efek samping dari Gestin F2, dibandingkan dengan Cyclofem, setelah dua belas bulan pemakaian 13 $(3.80 \%)$ peserta dan $3(0.90 \%)$ peserta. Problem yang terutama adalah Flour albus. Injeksi kontrasepsi dapat dikatakan efektif untuk 12 bulan pemakaian, dengan angka kegagalan (0.1\%). Penerimaan injeksi Gestin F-2 were 87 per 100 wanita; dan cyclofem injeksi 85 per 100 wanita.

Kesimpulan: Efek samping yang terutama adalah flour albus. Tidak dijumpai efek yang tidak diinginkan dari subjek. Kejadian yang tidak diinginkan dalam batas normal yang tidak memerlukan interfensi untuk aktifitas kesehatan. Gestin F2 dan Cyclofem keduanya dapat dihubungkan dengan banyak peserta yang puas dan toleransi yang baik.

Kata kunci: kontrasepsi injeksi, Gestin F2, Cyclofem, Efek Samping.

\section{VAGINISMUS BUKAN KURANG RILEKS: INFERTILITAS YANG TERBENGKALAI}

\author{
Robbi Asri Wicaksono $^{1}$, Tono Djuwantono ${ }^{2}$ \\ ${ }^{1}$ Bagian Obstetri \& Ginekologi Rumah Sakit Ibu Anak \\ Limijati Bandung, ${ }^{2}$ Bagian Obstetri \& Ginekologi \\ RSUP Dr. Hasan Sadikin-FK Universitas Padjajaran \\ Bandung)
}

Latar Belakang: Vaginismus adalah penyakit ginekologis yang cenderung diabaikan dan jarang didiskusikan pada pertemuan ilmiah kedokteran. Respon keliru "Anda hanya kurang rileks!", membuat pasien tersudutkan tanpa mendapatkan solusi medis. Penetrasi vagina (seksual dan non seksual) tidak bisa terjadi pada penderita vaginismus, sehingga pemeriksaan medis yang melalui vagina juga tidak dapat dilakukan. Padahal pemeriksaan-pemeriksaan itu sangat diperlukan untuk diagnostik dan tindak lanjut penyakit organ reproduksi, serta reproduksi berbantu. Pasca dilakukan prosedur dilatasi berbantu (total intravenous anesthesia, injeksi botulinum toxin tipe $\mathrm{A}$, dilatasi progresif, supervisi dilatasi), pasien dapat dilakukan pemeriksaan medis melalui vagina. 
Tujuan: Memaparkan informasi vaginismus dari sudut pandang infertilitas sehingga bisa meminimalisasi kebuntuan yang sering terjadi.

Metode: Penelitian deskriptif ini merupakan pelayanan pasien vaginismus di RSIA Limijati Bandung, periode Januari 2017-April 2019, dengan jumlah pasien 374 orang. Pemantauan hasil dilakukan bertahap setiap bulan hingga tujuan tercapai, atau melalui konfirmasi personal setiap pasien kepada dokter penanggung jawab.

Hasil: Rata-rata usia pasien 30,3 tahun, termuda 21, tertua 56 tahun. Lama menikah/aktif secara seksual, rata-rata 3,97 tahun, tersingkat 1 bulan, terlama 25 tahun. Merupakan kasus infertilitas primer $95,46 \%$, non infertilitas (mengalami splash pregnancy) sebanyak 17 kasus. Ditemukan 10 kasus vaginismus yang dengan endometriosis yang terbengkalai. Pada 9 kasus, sebelumnya telah dilakukan teknik reproduksi berbantu tanpa USG transvaginal/disertai pembiusan. Derajat keparahan vaginismus pasien, I (1), II (9), III (67), IV (236), V (61). Jumlah total prosedur dilatasi berbantu 235. Keberhasilan melakukan dilatasi mandiri pasca prosedur 99,5\%. Keberhasilan pemeriksaan medis melalui vagina $97,7 \%$. Rata-rata keberhasilan penetrasi penis 75,9\% dalam 4,6 minggu. Pasca prosedur dilatasi berbantu, pasien mengalami kehamilan alami pada 55 pasien.

Kesimpulan: Vaginismus merupakan masalah infertilitas yang nyata dan memerlukan perhatian khusus agar solusi medis dapat diberikan. Keberhasilan pemeriksaan medis pasca prosedur dilatasi berbantu dapat dicapai secara nyata, sehingga pemeriksaan medis dan teknik reproduksi berbantu dapat dilakukan tanpa kendala yang berarti.

Kata kunci: Vaginismus, infertilitas, dilatasi

\section{FAKTOR-FAKTOR YANG BERPENGARUH TERHADAP KEBERHASILAN INSEMINASI INTRA UTERIN (IIU) PROTOKOL KLOMIFEN SITRAT DAN GONADOTROPIN DI RUMAH SAKIT UMUM BALI ROYAL, DENPASAR, BALI}

\author{
Made Angga Diningrat ${ }^{1}$, Anom Suardika ${ }^{2}$, IB Putra \\ Adnyana $^{2}$ \\ 1.PPDS-2 Fertilitas dan Endokrinologi Reproduksi \\ Departemen/KSM Obstetrik dan Ginekologi FK \\ UNUD/RSUP Sanglah, Denpasar, Bali, ${ }^{2}$ Staff Divisi \\ Fertilitas dan Endokrinologi Reproduksi, Departemen/ \\ KSM Obstetrik dan Ginekologi FK UNUD/RSUP \\ Sanglah, Denpasar, Bali
}

Latar Belakang: Angka keberhasilan inseminasi intrauterin (IIU) di Indonesia secara umum masih sangat beragam. Pemahaman mengenai faktor-faktor penentu keberhasilan program IIU sangat penting dan dapat menjadi acuan untuk evaluasi tahapan IIU serta memaksimalkan setiap aspek dalam IIU sehingga dapat meningkatkan keberhasilan angka kehamilan dan bayi lahir hidup sesuai harapan.

Tujuan: Mengetahui faktor-faktor yang mempengaruhi keberhasilan inseminasi intra uterin (IIU) protokol klomifen sitrat dan gonadotropin di Rumah Sakit Umum Bali Royal, Denpasar, Bali.

Metode: Penelitian ini merupakan penelitian observasional dengan metode potong lintang (cross sectional) yang melibatkan 70 pasangan suami istri yang menjalani program inseminasi intra uterin (IIU) protokol klomifen sitrat dan gonadotropin di Rumah Sakit Umum Bali Royal, Denpasar, Bali selama periode 1 Januari 2018 sampai dengan 31 Desember 2018 yang tercatat dalam rekam medik. Variabel yang diteliti antara lain faktor istri (usia, ketebalan endometrium, jumlah folikel preovulasi, diameter folikel pre-ovulasi) dan faktor suami (jumlah sperma, konsentrasi sperma, motilitas sperma). Luaran yang dinilai adalah terjadinya kehamilan.

Hasil: Angka keberhasilan program inseminasi intrauterin (IIU) protokol klomifen sitrat dan gonadotropin di Rumah Sakit Umum Bali Royal, Denpasar, Bali adalah sebesar 17,1\% (12/70 kasus). Faktor yang berpengaruh secara signifikan adalah diameter folikel pre-ovulasi $(\mathrm{p}=0,000)$ dan jumlah folikel pre-ovulasi $(\mathrm{p}=0,000)$. Faktor usia istri, usia suami, jumlah sperma, konsentrasi sperma, ketebalan endometrium, dan motilitas sperma tidak berpengaruh signifikan ( $p>0,05)$.

Kesimpulan: Faktor diameter folikel pre-ovulasi dan jumlah folikel pre-ovulasi berhubungan dengan keberhasilan program inseminasi intrauterin (IIU) protokol klomifen sitrat dan gonadotropin di Rumah Sakit Umum Bali Royal, Denpasar, Bali.

Kata kunci: IIU, keberhasilan, RS Bali Royal

\section{PERBEDAAN EKSPRESI PROTEIN GENE PRODUCT 9.5 (PGP 9.5) PADA PROSES NEUROGENESIS DALAM KASUS MIOMA UTERI DISERTAI NYERI DENGAN MINOMA UTERI TANPA NYERI}

\author{
Aya Sofia Filayeti
}

\section{Departemen Kebidanan dan Kandungan RS Hasan Sadikin/ Fakultas Kedokteran Universitas Padjajaran}

Tujuan:: Tujuan penelitian untuk mengetahui perbedaan neurogenesis melalui ekspresi PGP 9.5 pada penderita mioma uteri dengan dan tanpa nyeri. 
Metode: Jenis penelitian studi kontrol. Jumlah sampel sebanyak 92 yang terdiri dari 62 mioma uteri dan 30 uterus normal. Data yang digunakan data primer. Analisa data menggunakan Chi-Square, Mann-Whitney, dan Analisis korelasi rank.

Hasil: Ekspresi PGP 9.5 pada mioma uteri dibandingkan uterus normal, terdapat perbedaan yang bermakna pada intensitas, distribusi dan histoskor. Ekspresi PGP 9.5 pada mioma uteri dengan nyeri lebih tinggi dibandingkan mioma uteri tanpa nyeri dilihat dari intensitas dan distribusi (Chi-Square, $\mathrm{p}<0,001$ ) serta pada nilai histoskor (Mann-Whitney). Nilai histoskor PGP 9.5 berhubungan dengan ukuran mioma yang bermakna $(\mathrm{p}<0,001)$ secara statistik pada mioma uteri dengan nyeri, berdasarkan uji rank Spearman.

Kesimpulan: Ekspresi PGP 9.5 tidak ditemukan pada uterus normal. Makin kuat ekspresi PGP 9.5 pada mioma uteri yang mengalami nyeri, maka makin nyeri. PGP 9.5 dapat mendeteksi neurogenesis pada mioma uteri.

Kata Kunci: neurogenesis, ekspresi PGP 9.5, mioma uteri, nyeri

\section{ENDOMETRIUM TIPIS TIDAK RESPON DENGAN TERAPI HORMONAL: LAPORAN KASUS}

Charly Haposan, Riyan Hari Kurniawan, Raden

Muharam

\section{Fakultas Kedokteran, Departemen Obstetri dan Ginekologi, Universitas Indonesia}

Latar belakang: Endometrium tipis merupakan faktor resiko amenorea sekunder (5,1 mm (95\% CI: 4,27,5)) dapat disebabkan oleh riwayat kuretase sebelumnya dan gangguan aksis hipotalamus-pituitaridan ovarium. 1 Pada beberapa kasus dapat disebabkan oleh endometritis sehingga perlu mendapat terapi antibiotik (angka sensitivitas 81\%, namun angka spesifitas $12 \%) .^{2}$ Suatu studi menyebutkan endometrium tipis merupakan faktor resiko menyebabkan infertilitas. $\underline{3}$

Laporan Kasus: Pasien dengan kondisi tidak mengalami menstruasi selama 3 bulan pasca kuretase atas indikasi abortus inkomplit. Diberikan terapi hormonal dengan kontrasepsi Pil Oral Kombinasi selama sebulan dan kombinasi anti androgen dan estradiol, namun tidak terdapat respons. Hasil USG endometrium dengan tebal $2 \mathrm{~mm}$. Terapi kombinasi anti androgen dan estradiol, tidak menunjukkan hasil signifikan. Ketebalan endometrium hanya mencapai maksimal $5 \mathrm{~mm}$. Pasca terapi kombinasi anti androgen dan estradiol terdapat perdarahan withdrawal yang siklik.Pada pasien dipikirkan untuk dilakukan terapi stem cell pada jaringan endometrium, dengan penyuntikan platelet rich plasma subendometrial atau pengaplikasian selaput amnion pada endometrium.

Diskusi: Endometrium tipis dapat disebabkan oleh faktor vaskularisasi dan infeksi endometrium. Sehingga tatalaksana dapat diberikan sesuai faktor resiko. Pada pemberian hormonal dapat memberikan efek penebalan hingga lebih dari $7 \mathrm{~mm}$ dan keberhasilan kehamilan hingga $70 \%$ pada pemberian Estradiol pervaginam. Sedangkan keberhasilan penurunan angka amenorrhea pada pasien yang menjalani operasi amniotic graft dari $39 \%$ (preoperatif) hingga sebesar 4,3\% (postoperatif). 4

Kesimpulan: Endometrial tipis dapat menjadi faktor resiko amenorea sekunder. Dari hasil pemeriksaan menunjukkan penipisan endometrium yang tidak responsif terhadap terapi hormonal. Untuk kasus ini masih dianggap sebagai endometritis dan mendapat terapi antibiotik. Pada saat ini modalitas terapi terbaru dengan stem cell dipikirkan juga untuk regenerasi jaringan endometrium.

Kata kunci: Endometrium tipis, amenorea sekunder, stem cell.

\section{HIPOTIROD SEBAGAI PENYEBAB KISTA OVARIUM REVERSIBEL. SEBUAH KASUS TENTANG SINDROM VAN WYK DAN GRUMBACH}

Elia T, Nusrattudin A, Suzanna S.P

Divisi Fertilitas dan Endokrinologi Bagian Obstetri dan Ginekologi, Fakultas Kedokteran Universitas Hasanuddin

Latar belakang: Hipotiroid perlu dipertimbangkan pada pasien dengan kista ovarium, Walaupun kasus sindrom Van Wyk and Grumbach jarang, menjadi krusial untuk menghindari pembedahan yang tidak perlu.

Tujuan: Melaporkan dan memberikan gambaran singkat mengenai sindrom van wyk and Grumbach syndrome

Laporan kasus: Kami melaporkan anak perempuan 7 tahun datang dengan perdarahan pervaginam yang disertai pembesaran payudara bilateral tanner 5, dari pemeriksaan fisis didapatkan kista ovarium kanan yang besar disertai multikistik ovarium kiri, Hipotiroid berat dan peningkatan hormon prolactin, esterogen, TSH yang signifikan sehingga kami mendiagnosis pasien dengan van wyk dan grumbach syndrome, dan diputuskan untuk memberikan terapi pengganti hormone tiroid selama 3 bulan 
Hasil: Setelah pemberian hormone tiroid selama 3 bulan terjadi penurunan ukuran payudara, Perdarahan pervaginam yang terhenti, disertai, regeresi dari kista ovarium kiri dan kanan, penurunan kadar hormon prolactin, esterogen, dan TSH.

Kesimpulan: Pada laporan kasus ini kami melaporkan anak perempuan yang berumur 7 tahun dengan yang menderita van wijk and grumbach syndrome, yang mengalami regresi spontan dengan pemeberian terpai pengganti hormon tiroid. Hipotiroid perlu dipertimbangkan pada pasien dengan kista ovarium, Walaupun kasus sindrom Van Wyk and Grumbach jarang, menjadi krusial untuk menghindari pembedahan yang tidak perlu ovarium

Kata Kunci: Hipotiroid, Pubertas prekoks, Kista

\section{LUARAN FERTILISASI IN VITRO PADA PASIEN AZOOSPERMIA DIBANDINGKAN DENGAN OKLUSI TUBA}

Elisia Atnil ${ }^{1}$, Anggi Lewis Reso Putro ${ }^{1}$, Budi Wiweko $^{1,2}$, Oki Riayati ${ }^{1}$, Sarah Zakirah ${ }^{1}$, R Muharam ${ }^{1,2}$, Andon Hestiantoro $^{1,2}$, Achmad Kemal Harzif ${ }^{1,2}$, Gita Pratama $^{1,2}$, Eliza Mansyur ${ }^{2}$, Tita Yuningsih ${ }^{2}$, Siti Mariyam $^{2}$, Endang Purdiningsih ${ }^{2}$

${ }^{1}$ Human Reproductive, Infertility and Family Planning Research Center, Indonesia Medical Education and Research Institute (IMERI), Fakultas Kedokteran Universitas Indonesia, ${ }^{2}$ Klinik IVF Yasmin, Rumah Sakit Cipto Mangunkusumo

Latar Belakang: Fertilisasi in vitro merupakan salah satu teknik reproduksi buatan untuk membantu pasangan dengan masalah infertilitas untuk mencapai kehamilan. Keberhasilan konsepsi ditentukan oleh faktor fertilitas pria dan wanita. Secara statistik, faktor pria berpengaruh $30-40 \%$, wanita $40-55 \%$, dan keduanya $10 \%$. Infertilitas merupakan sebuah masalah yang banyak ditemukan pada pasangan dengan berbagai penyebab yang berbeda. Salah satu penyebab infertilitas pada pria adalah azoospermia, sedangkan pada wanita adalah oklusi tuba.

Tujuan:.Mengetahui luaran fertlisasi in vitro pada pasien azoospermia dibandingkan dengan oklusi tuba.

Metode: Penelitian ini merupakan penelitian analitik potong lintang retrospektif yang dilakukan di Klinik Yasmin, Rumah Sakit Cipto Mangunkusumo di Jakarta, Indonesia dari tahun 2013 - 2018. Penelitian dilakukan pada pasangan infertil yang ingin melakukan IVF, dan dibagi menjadi dua kelompok sesuai indikasi IVF. Didapatkan 115 pasien dalam kelompok azoospermia dan 178 pasien dalam kelompok oklusi tuba. Hasil IVF pada kedua kelompok dicatat, dan dinyatakan positif apabila ditemukan denyut jantung janin pada usia kehamilan $3-4$ minggu dengan menggunakan USG. Data kemudian dianalisa dengan menggunakan SPSS dan analisa statistik dengan uji chi square.

Hasil: Dari 106 pasien yang termasuk dalam kelompok azoospermia, sebagian besar $(43,4 \%)$ berusia $>40$ tahun. Sebanyak $83 \%$ pasien mengalami infertilitas primer. Pada kelompok oklusi tuba terdapat 193 pasien, dimana sebagian besar $(59,6 \%)$ berusia $<35$ tahun dan sebanyak 26,9\% memiliki IMT 18,5 - 22,9. Sebagian besar dari kelompok oklusi tuba mengalami infertilas primer $(85 \%)$. Kehamilan pada kelompok azoospermia dan oklusi tuba berturut - turut adalah $28,3 \%$ dan $24,4 \%$ dengan nilai $\mathrm{P}=0,45$.

Kesimpulan: Tidak terdapat perbedaan yang signifikan pada luaran fertilisasi pasien azoospermia dibandingkan dengan pasien oklusi tuba.

Kata Kunci: Fertilisasi in Vitro, Azoospermia, Oklusi Tuba

\section{LAJU KEHAMILAN PADA PASIEN FERTILISASI IN VITRO YANG BERUSIA LEBIH DARI 40 TAHUN}

Elisia Atnil ${ }^{1}$, Anggi Lewis Reso Putro ${ }^{1}$, Budi Wiweko $^{1,2}$, Oki Riayati ${ }^{1}$, Sarah Zakirah ${ }^{1}$, R Muharam ${ }^{1,2}$, Andon Hestiantoro ${ }^{1,2}$, Achmad Kemal Harzif ${ }^{1,2}$, Gita Pratama $^{1,2}$, Eliza Mansyur ${ }^{2}$, Tita Yuningsih ${ }^{2}$, Siti Mariyam $^{2}$, Endang Purdiningsih ${ }^{2}$

\section{${ }^{1}$ Human Reproductive, Infertility and Family Planning Research Center, Indonesia Medical Education and Research Institute (IMERI), Fakultas Kedokteran Universitas Indonesia, \\ ${ }^{2}$ Klinik IVF Yasmin, Rumah Sakit Cipto Mangunkusumo $^{2}$}

Latar Belakang: Kegagalan implantasi setelah transfer embrio sampai saat ini masih menjadi salah satu masalah terpenting dalam fertilisasi in vitro (FIV). Salah satu faktor yang berperan adalah usia. Telah diketahui bahwa dengan penambahan usia, terdapat pengurangan respon pada stimulasi ovarium, jumlah oosit yang berkurang, dan kualitas oosit yang menurun, yang tentu saja nantinya akan mempengaruhi keberhasilan implantasi.

Tujuan: Mengetahui laju kehamilan pada pasien fertilisasi in vitro yang berusia lebih dari 40 tahun.

Metode: Penelitian ini merupakan penelitian analitik potong lintang retrospektif yang dilakukan di Klinik Yasmin, Rumah Sakit Cipto Mangunkusumo, Jakarta, Indonesia. Data diambil dari rekam medis 
pasien infertil yang mengikuti program FIV dari tahun 2013 - 2018. Usia wanita dan evaluasi kehamilan dicatat. Data kemudian dianalisa dengan menggunakan SPSS dan analisa statistik dengan uji chi square.

Hasil: Dari 1637 pasien yang mengikuti program FIV, sebagian besar $(69 \%)$ melakukan transfer embrio segar. Sebanyak 24,1\% memiliki IMT 18,5 - 22,9. Sebagian besar subjek dalam penelitian mengalami infertilitas primer, yaitu sebanyak 86,2\%. Pasien kemudian dibagi menjadi dua kelompok berdasarkan usia, yaitu $\leq 40$ tahun sebanyak 1402 orang dan $>40$ tahun sebanyak 235 orang. Rata-rata durasi infertilitas pada kelompok usia $\leq 40$ tahun adalah 7 (1-23) tahun dan pada kelompok $>40$ tahun adalah 9 (1-21). Median jumlah oosit pada kedua kelompok berturut - turut adalah 9 (1-47) dan 4 (1-31), dengan nilai $\mathrm{P}=0,00$. Pengukuran kadar AMH juga dilakukan, dan didapatkan median sebesar 2,4 (0,01-34,06) dan 1,2 (0,01-19,20), dengan nilai $\mathrm{P}=0,00$. Laju kehamilan pada kedua kelompok berturut - turut adalah $28,7 \%$ dan $10,6 \%$ dengan $\mathrm{P}=0,00$.

Kesimpulan: Terdapat perbedaan yang signifikan pada kedua kelompok usia, baik dari segi durasi infertilitas, jumlah oosit, kadar $\mathrm{AMH}$, dan juga laju kehamilan. Peluang keberhasilan hamil dengan FIV ditemukan lebih tinggi secara signifikan pada kelompok usia $\leq 40$ tahun.

Kata Kunci: Infertilitas, Usia, FIV

\section{PERBANDINGAN FRAGMENTASI DNA FOLIKEL PRIMORDIAL JARINGAN KORTEKS OVARIUM FRESH NON TRANSPLAN, FRESH TRANSPLAN, VITRIFIKASI NON TRANSPLAN DAN VITRIFIKASI TRANSPLAN PADA MODEL BINATANG}

Edy Priyanto $^{1}$, Shofwal Widad ${ }^{2}$, Agung Dewanto ${ }^{2}$

${ }^{1}$ Fakultas Kedokteran Universitas Jenderal Soedirman/RSUD Prof. dr. Margono Soekarjo Purwokerto, ${ }^{2}$ Fakultas Kedokteran, Kesehatan Masyarakat dan Keperawatan Universitas Gadjah Mada/RSUP dr.Sardjito Yogyakarta

Latar Belakang: Kriopreservasi jaringan ovarium merupakan salah satu pendekatan cara mempertahankan fertilitas pada wanita yang diprediksi mengalami kegagalan ovarium prematur sebagai konsekuensi dari kemoterapi, radioterapi atau kelainan genetik. Kriopreservasi dengan vitrifikasi menjadi fokus investigasi meskipun masih terdapat kontroversi terhadap hasil akhirnya, karena belum ada protokol optimal untuk vitrifikasi serta data vitrifikasi jaringan ovarium manusia masih terbatas dan berlainan hasil

Tujuan: Mengevaluasi metode vitrifikasi modifikasi Suzuki pada folikel primordial jaringan korteks ovarium

Metode: Metode penelitian ini menggunakan uji eksperimental jenis one shot case study dengan menggunakan 28 jaringan korteks ovarium kambing (Capra aegagrus hircus) yang terbagi dalam 4 perlakuan yaitu jaringan korteks ovarium fresh non transplan, jaringan fresh ditransplantasikan ke CAM (chorioallantoic membrane) ayam, jaringan di vitrifikasi non transplan dan jaringan di vitrifikasi yang ditransplantasikan ke CAM. Penilaian fragmentasi DNA folikel primordial pada setiap grup dilakukan dengan metode TUNEL (TdT-mediated dUTP-biotin nick end labeling) yang dilakukan di laboratorium fisiologi Fakultas Kedokteran, Kesehatan Masyarakat dan Keperawatan Universitas Gadjah Mada Yogyakarta. Analisis statistik data penelitian dilakukan dengan uji ANOVA.

Hasil: Rerata fragmentasi DNA pada grup fresh non transplan: $2.71( \pm 2.75)$, fresh transplan: $2.14( \pm$ 1.06), vitrifikasi non transplan: 1.71 ( \pm 1.6) dan vitrifikasi transplan $1.71( \pm 1.79)$. Uji komparasi 4 grup didapatkan $\mathrm{p}=0.731(\mathrm{p}<0.05)$.

Kesimpulan: Tidak terdapat perbedaan signifikan fragmentasi DNA folikel primordial jaringan korteks ovarium antara fresh non transplan, fresh transplan, vitrifikasi non transplan dan vitrifikasi transplan yang menunjukkan metode vitrifikasi modifikasi Suzuki dapat mempertahankan folikel dari fragmentasi DNA.

Kata Kunci: Kriopreservasi, vitrifikasi, fragmentasi DNA, TUNEL

\section{KEBERHASILAN DAN KEGAGALAN PRESERVASI FERTILITAS PADA PENDERITA KANKER DI INDONESIA : SEBUAH PEMBELAJARAN DARI SERIAL KASUS}

\author{
Achmad Kemal Harzif ${ }^{1,2,3}$,Shofi Faiza ${ }^{1}$,Heidi Dewi \\ Mutia $^{1}$, Mila Maidarti ${ }^{1,2,3}$, Budi Wiweko ${ }^{1,2,3}$ \\ ${ }^{1}$ Indonesian Reproductive Medicine Research and \\ Training Center, ${ }^{2}$ Departemen Obstetri dan Ginekologi \\ RSUP Cipto Mangunkusumo, ${ }^{3}$ Fakultas Kedokteran \\ Universitas Indonesia
}

Tujuan: Pengobatan kanker mempengaruhi fungsi reproduksi wanita karena dapat merusak ovarium. Hilangnya kesuburan dapat menjadi permasalahan pada penderita kanker. Namun, Preservasi Fertilitas saat ini sudah tersedia. Studi kasus ini membandingkan kasus 
yang berhasil dan gagal dalam menyediakan preservasi fertilitas pada penderita kanker di Indonesia.

Laporan Kasus: Kasus 1. Seorang wanita, 20 tahun, belum menikah, dengan tumor ovarium sel germinal, AMH $1.27 \mathrm{ng} / \mathrm{ml}$. Pasien telah dilakukan pembedahan fertilitysparing dan berencana untuk kemoterapi. Pasien telah mendapat informasi dari dokter tentang preservasi fertilitas dan setuju untuk dilakukan oocyte pickup. Stimulasi ovarium dilakukan sebelum prosedur. 15 oosit berhasil dibekukan. Kasus 2. Seorang wanita, 17 tahun, belum menikah, dengan tumor ovarium tipe yolk sac, telah menjalani pembedahan fertility sparing, AMH 0,6 ng/ml. Pasien dikonsultasikan sehari sebelum kemoterapi, namun pasien menolak untuk menjalani prosedur Preservasi Fertilitas. Berdasarkan wawancara, orang tua pasien dengan menyesal mengatakan seandainya mereka mendapatkan informasi lebih awal, mungkin akan memilih untuk menjalani preservasi fertilitas. Pada kasus ini, terdapat pembelajaran bahwa semakin awal informasi mengenai preservasi fertilitas diberikan secara lengkap, memiliki dampak positif untuk keberhasilan program ini.

Kesimpulan: Informasi yang komprehensif tentang preservasi fertilitas dapat mempengaruhi keputusan pasien yang mengarah pada tingkat keberhasilan program ini.

Kata kunci: Preservasi fertilitas, kanker ovarium, tatalaksana kanker.

\section{KELUHAN MENOPAUSE PADA PASIEN KANKER SERVIKS PASCA RADIASI KOMPLIT MENGGUNAKAN MENOPAUSE QUALITY OF LIFE (MENQOL)}

Iman Helmi Effendi, M. Gamal Darus, M. Fidel Ganis Siregar, Riza Rivany, Hotma Partogi Pasaribu, M. Rhiza Z. Tala, Cut Adeya Adella

Tujuan: Untuk mengetahui keluhan dan kualitas hidup pasien-pasien kanker serviks pasca radiasi komplit yang telah mengalami menopause dengan menggunakan Menopause Quality of Life (MENQOL). Metode: Penelitian ini adalah suatu penelitian deskriptif dengan pendekatan poting lintang. Hasil: Dari 52 orang subjek penelitian, 71,2\% berada pada kelompok usia 3545 tahun, $59,7 \%$ telah mengalami menopause 7-12 bulan, 63,5\% penderita kanker serviks stadium IIB. Menggunakan MENQOL, pada dimensi vasomotor semua keluhan dialami oleh sebahagian besar subjek, pada dimensi psikososial, keluhan terbesar adalah depresi (81\%), pada dimensi fisik keluhan terbesar adalah merasa cepat lelah dan nyeri otot/sendi masingmasing 90\%. dan pada dimensi seksual semua subjek mengalmi penurunan keinginan seksual dan menghindar dari hubungan intim (100\%). Kesimpulan: penderita kanker serviks yang telah menjalani radiasi komplit mengalami menopause dan mengalami penurunan kualitas hidup yang cukup berarti.

Kata kunci: Menopause, kanker serviks pasca radiasi komplit, MENQOL.

\section{APLIKASI AMNIOTIC GRAFT PADA SINDROM ASHERMAN}

Sulaeman Andrianto Susilo, Agus Surur

Latar belakang: Adesi intrauterin/Sindrom Asherman dapat terjadi setelah prosedur intrauterin invasif yang disebabkan proses penyembuhan dari kerusakan endometrium/miometrium. Gejala yang ditimbulkan seperti amenore, dengan atau tanpa nyeri haid berat, oligomenore, infertilitas, atau keguguran berulang. Sindrom ini terjadi paling banyak karena kuretase berulang oleh abortus inkompit (50\%), perdarahan postpartum (24\%), dan aborsi elektif $(17.5 \%)$.

Ilustrasi kasus: Ny A, 34 tahun, P0A1 pada tahun 2010 dilakukan kuretase ai kematian mudigah di RSUD Pasar Rebo. Pada tahun 2016 dilakukan histeroskopi reseksi, didiagnosis dengan SA. Pada pertengahan 2018 pasien dilakukan histeroskopi ulang dan dipasang IUD karena keluhan menstruasi sedikit. Awal 2019 pasien berobat kembali dengan keluhan tidak menstruasi, sehingga diputuskan untuk dilakukan pemasangan amniotic graft. Tiga bulan kemudian pasca aplikasi amnion graft, pasien melaporkan menstruasi kembali dengan lama haid 3 hari, ganti pembalut 3 kali per harinya.

Diskusi: Terapi pemberian selaput ketuban (amniotic membrane graft) berhubungan dengan durasi menstruasi, dan risiko rekurensi dari adesi intrauterin berat. Penelitian lain menunjukkan bahwa amniotic graft meningkatkan volume menstruasi darah setelah histeroskopi adesiolosis. Namun terapi ini gagal mengurangi rekurensi adesi intrauterin dan tidak berhubungan dengan kehamilan pascaterapi. Berdasarkan Lugan et al, penggunaan amniotic graft setelah prosedur histeroskopi dapat mengurangi adesi intrauterin lebih kuat dibandingkan tampak histeroskopi

Kesimpulan: Sindrom Asherman merupakan suatu penyakit kompleks yang dapat mengganggu kualitas hidup seseorang.Pada pasien ini kesuksesan dari terapi ini adalah kembalinya haid pasien kembali. Namun, pada pasien ini perlu adanya evaluasi lebih lanjut dari dinding endometrium dan kejadian kehamilan. Aplikasi amnion graft dapat menjadi suatu pilihan untuk terapi SA. 


\section{ENDOMETRIUM TIPIS TIDAK RESPON DENGAN TERAPI HORMONAL}

Charly Haposan, Riyan Hari Kurniawan, Raden

Muharam

\section{Fakultas Kedokteran, Departemen Obstetri dan} Ginekologi, Universitas Indonesia

Latar belakang: Endometrium tipis merupakan faktor resiko amenorea sekunder (5,1 mm (95\% CI: 4,2$7,5)$ ) dapat disebabkan oleh riwayat kureta sebelumnya dan gangguan aksishipotalamus pituitari-dan ovarium. Pada beberapa kasus dapat disebabkan oleh endometritis sehingga perlu mendapat terapi antibiotik ( angka sensitivitas $81 \%$, namun angka spesifitas $12 \%$ ). Suatu studi menyebutkan endometrium tipis merupakan faktor resiko menyebabkan infertilitas.

Laporan kasus: Pasien dengan kondisi tidak mengalami menstruasiselama 3 bulan pasca kureta seatas indikasi abortus inkomplit. Diberikan terapi hormonal dengan kontrasepsi Pil Oral Kombinasi selama sebulan dan kombinasi anti androgen dan estradiol, namun tidak terdapat respons. Hasil USG endometrium dengan tebal $2 \mathrm{~mm}$. Terapi kombinasi anti androgen dan estradiol, tidak menunjukkan hasil signifikan. Ketebalan endometrium hanya mencapai maksimal $5 \mathrm{~mm}$. Pasca terapi kombinasi anti androgen dan estradiol terdapat perdarahan with drawal yang siklik. Pada pasien dipikirkan untuk dilakukan terapi stem cell pada jaringan endometrium, dengan penyuntikan platelet rich plasma sub endometrial atau pengaplikasian selaput amnion pada endometrium.

Diskusi: Endometrium tipis dapat disebabkan oleh faktor vaskularisasi dan infeksi endometrium. Sehingga tatalaksana dapat diberikan sesuai faktor resiko. Pada pemberian hormonal dapat memberikan efek penebalan hingga lebih dari $7 \mathrm{~mm}$ dan keberhasilan kehamilan hingga $70 \%$ pada pemberian Estradiol pervaginam. Sedangkan keberhasilan penurunan angka amenorrhea pada pasien yang menjalani operasi amniotic graftdari $39 \%$ (preoperatif) hinggasebesar 4,3\% (postoperatif).

Kesimpulan: Endometrial tipis dapat menjadi faktor resiko amenorea sekunder. Dari hasil pemeriksaan menunjukkan penipisan endometrium yang tidak responsif terhadap terapi hormonal. Untuk kasus ini masih dianggap sebagai endometritis dan mendapat terapi antibiotik. Pada saat ini modalitas terapi terbaru dengan stem cell dipikirkan juga untuk regenerasi jaringan endometrium.

Kata kunci: Endometrium tipis, amenorea sekunder, stem cell.

\section{HIPOTIROD SEBAGAI PENYEBAB KISTA OVARIUM REVERSIBEL SEBUAH KASUS TENTANG SINDROM VAN WYK DAN GRUMBACH}

\author{
Elia Tombe M, Nusrattudin A, Suzanna S.P
}

Divisi Fertilitas dan Endokrinologi Bagian Obstetri dan Ginekologi, Fakultas KedokteranUniversitas

Hasanuddin

Email : eliatombe@gmail.com,082190246300

Latar belakang: Hipotiroid perlu dipertimbangkan pada pasien dengan kista ovarium, walaupun kasus sindrom Van Wyk and Grumbach jarang, menjadi krusial untuk menghindari pembedahan yang tidak perlu.

Tujuan: Melaporkan dan memberikan gambaran singkat mengenai sindrom van wyk and Grumbach syndrome

Laporan kasus: Kami melaporkan anak perempuan 7 tahun datang dengan perdarahan pervaginam yang disertai pembesaran payudara bilateral tanner 5, dari pemeriksaan fisis didapatkan kista ovarium kanan yang besar disertai multikistik ovarium kiri, hipotiroidberat dan peningkatan hormon prolactin, esterogen, TSH yang signifikan sehingga kami mendiagnosis pasien dengan van wyk dan grumbach syndrome, dan diputuskan untuk memberikan terapi pengganti hormone tiroid selama 3 bulan.

Hasil: Setelah pemberian hormone tiroid selama 3 bulan terjadi penurunan ukuran payudara, perdarahan pervaginam yang terhenti, disertai, regeresi dari kista ovarium kiri dan kanan, penurunan kadar hormon prolactin, esterogen, dan TSH.

Kesimpulan dan saran: Pada laporankasus ini kami melaporkan anak perempuan yang berumur 7 tahun dengan yang menderita van wijk and grumbach syndrome, yang mengalami regresi spontan dengan pemeberian terpai pengganti hormon tiroid. Hipotiroid perlu dipertimbangkan pada pasien dengan kista ovarium, walaupun kasus sindrom Van Wyk and Grumbach jarang, menjadi krusial untuk menghindari pembedahan yang tidak perlu.

Kata kunci: Hipotiroid, pubertas prekoks, kista ovarium

\section{HASIL PATOLOGI ANATOMI OPERASI HISTERESKOPI OPERATIF DI RSUP DR. KARIADI SEMARANG TAHUN 2015-2018}

Yoshi Riantyoko $^{1}$, Hary Tjahjanto ${ }^{2}$ 
Bagian/SMF Obstetri Ginekologi FK Undip/RSUP Dr. Kariadi Semarang, ${ }^{1}$ Residen PPDS-1 Obstetri dan Ginekologi, Fakultas Kedokteran Universitas Diponegoro, RSUP Dr. Kariadi Semarang ${ }^{2}$ Staf Pengajar Divisi Fertilitas, Endokrinologi dan Reproduksi PPDS-1 Obstetri dan Ginekologi, Fakultas Kedokteran Universitas Diponegoro, RSUP Dr. Kariadi Semarang

Latar belakang: Histeroskopi merupakan suatu prosedur endoskopik untuk mendapatkan visualisasi langsung kanalis endoservikalis dan kavum uterus. Tindakan histeroskopi ditujukan sebagai prosedur diagnostik maupun operatif untuk kelainan ginekologi. Indikasi dilakukan histeroskopi untuk diagnostik bila hasil biopsi endometrium yang abnormal, curiga polip dan fibroid, perdarahan uterus abnormal, kasus infertilitas, evaluasi anatomi uterus, dan curiga IUD tidak pada posisi yang tepat. Sedangkan, indikasi untuk operatif, yaitu ablasi atau reseksi endometrium, polipektomi endometrium, biopsi langsung, miomektomi, pembuangan lesi pada endoservik, eksisi adhesi intrauterin, perbaikan septum uteri, sterilisasi histeroskopik, tuboplasti atau kanulasi, salphingography, dan Asherman's syndrome.

Tujuan: Mengetahui karakteristik hasil pemeriksaan patologi anatomi pada operasi histeroskopi operatif di RSUP Dr. Kariadi Semarang tahun 20152018.

Rancangan : Penelitian deskriptif observasional.

Metode: Penelitian ini menggunakan metode deskriptif terkait hasil pemeriksaan patologi anatomi pada operasi histeroskopi operatif di RSUP Dr. Kariadi, Semarang. Data diambil dari rekam medis pasien yang dilakukan operasi histeroskopi operatif selama periode 1 Januari 2015 - 31 Desember 2018.

Hasil: Selama kurun waktu 4 tahun terdapat 126 pasien yang dilakukan operasi histeroskopi operatif di RSUP Dr. Kariadi Semarang. Rerata usia pasien adalah $32,10 \pm 5,55$ tahun, usia termuda adalah 21 tahun dan usia tertua adalah 50 tahun. Tindakan histeroskopi paling banyak pada rentang umur 31-40 tahun, yaitu sebesar 61 kasus $(48,4 \%)$, diikuti rentang umur 21-30 tahun sebesar 54 kasus $(42,9 \%)$. Status infertilitas pada pasien dengan infertilitas primer sebesar $49,2 \%$ dan sekunder sebesar $1,6 \%$. Diagnosis terbanyak adalah polip endometrium yaitu 94 pasien $(74,60 \%)$, kemudian diikuti oleh AUB 25 pasien (19,85\%). Hasil patologi anatomi terbanyak adalah polip endometrium fungsional yaitu 64 pasien $(50,79 \%)$ kemudian diikuti oleh polip endometrium fungsional disertai servisitis 40 pasien $(31,74 \%)$, polip endometrium fungsional disertai endometritis 8 pasien $(6,35 \%)$, leimyoma uteri 8 pasien $(6,35 \%)$, polip endometrium fungsional disertai hiperplasia endometrium 6 pasien $(4,77 \%)$.
Kesimpulan: Selama periode 4 tahun, ditemukan bahwa polip endometrium merupakan diagnosis dan hasil patologi anatomi yang paling sering ditemui pada tindakan histeroskopi operatif di RSUP Dr. Kariadi Semarang.

Kata kunci: Histeroskopi, polip endometrium, infertilitas.

\section{EFEK FUKOSANTIN TERHADAP LUAS IMPLAN ENDOMETRIOSIS PADA MENCIT MODEL}

Rini Aryani, Stefani Harum Sari,Fathia Kesuma Dinanti

Tujuan: Mengetahui hubungan pemberian fukosantin, injeksi leuprolide acetate dan kombinasinya terhadap luas implan pada peritoneum mencit model endometriosis.

Metode: Desain penelitian eksperimental dengan rancangan post-test only group design. Penelitian dilakukan pada Juli - Desember 2018 di Fakultas Kedokteran Hewan Universitas Airlangga Surabaya. Mencit berjumlah 28 ekor yang memenuhi kriteria inklusi dibagi dalam empat kelompok masing-masing berjumlah 7 ekor. Kelompok kontrol positif (K), kelompok leuprolide acetate (P1) kelompok fukosantin (P2), kelompok kombinasi leuprolide acetate dan fukosantin (P3). Luas implan endometriosis diukur dari luas penampangnya, lalu diukur menggunakan tracing computer. Analisis data dilakukan dengan Kruskal Wallis dilanjutkan dengan uji perbedaan antarkelompok Post Hoc (Mann Whitney U Test).

Hasil: Didapatkan hasil yang bermakna pada perbedaan luas implan dengan $\mathrm{p}=0,001$. Rerata luas implan cenderung tinggi pada kelompok $\mathrm{K}$ (control positif) $(60,45 \hat{A} \pm 1,74)$ dan cenderung rendah pada kelompok P1 (Leuprolide acetate) $(25,79 \hat{\mathrm{A}} \pm 8,22)$.

Kesimpulan: Fukosantin mempunyai hubungan pada luas implan jaringan endometriosis di peritoneum mencit model pada ke-empat kelompok perlakuan.

Kata kunci: endometriosis, fukosantin, luas implan.

\section{OVARIAL ENDOMETRIOSIS PADA WANITA PASCA MENOPAUSE}

Setiaji J, Mamengko L, Laihad BJ

Department of Obstetrics and Gynecology, Faculty of Medicine University of Sam Ratulangi 
Latar belakang: Endometriosis adalah kelainan ginekologi jinak, estrogen dependent dengan gejala nyeri panggul dan infertilitas. Endometriosis dikaitkan dengan siklus menstruasi, 2\% hingga 5\% wanita pascamenopause mengalami endometriosis. Endometriosis pascamenopause merupakan penyakit yang jarang terjadi. Estrogen dependent dianggap penting pada proses patofisiologis. Endometriosis dapat berkembang pada wanita menopause yang menjalani terapi sulih hormon atau karena faktor lain, dan dapat disebabkan oleh estrogen eksogen atau mungkin independen. Meskipun ada beberapa laporan yang sukses dengan perawatan seperti aromatase inhibitor, pembedahan harus dilakukan sebagai langkah pertama dalam pengelolaan ovarium pascamenopause endometriosis.

Kasus: Wanita 69 tahun P0A0 mengeluh nyeri pada perut bagian bawah hilang timbul dan terdapat benjolan pada perut. Pasien menarche umur 15 tahun, nyeri saat haid dirasakan sejak awal haid, riwayat haid teratur dan menopause saat umur 51 tahun. Tidak ada riwayat penggunaan kontrasepsi. Pemeriksaan fisik didapatkan berat badan $65 \mathrm{~kg}$, tinggi badan $146 \mathrm{~cm}$ (BMI:30,5). Pemeriksaan abdomen tampak cembung dan teraba massa kistik setinggi 2 jari di bawah umbilikus. Pemeriksaan ginekologi adneksa sebelah kiri teraba massa kistik berukuran sebesar bola voli. Pemeriksaan laboratorium darah lengkap normal, Ca$12514,80 \mathrm{u} / \mathrm{ml}$. Pemeriksaan ultrasonografi tampak gambaran massa kistik berasal dari adneksa ukuran 12,3 cm x 8,06 cm x 11,1 cm dan CT-Scan abdomen-pelvik didapatkan kista multiloculated septa tipis dengan eggshell calcification ovarium kesan benigna ukuran $11,81 \mathrm{~cm}$ x $11,50 \mathrm{~cm}$ x 9,60 cm. Dilakukan laparotomi potong beku hasil patologi anatomi kista endometriosis ovarii.

Kesimpulan: Mekanisme terjadinya endometriosis pascamenopause masih belum jelas, kemungkinan terdapat produksi estrogen oleh lesi endometriotik itu sendiri ataupun faktor lain. Wanita dengan endometriosis pasca menopause memiliki risiko transformasi ganas lebih tinggi. Manajemen bedah direkomendasikan sebagai lini pertama pada wanita pasca menopause dengan endometriosis.

Kata kunci: Endometriosis, pasca menopause, kista.

\section{PERBANDINGAN TINGKAT KEBERHASILAN PREPARASI SPERMA METODE SWIM UP DENGAN DENSITAS GRADIEN PADA INSEMINASI INTRAUTERIN}

Irwansyah Putra
Departemen Obstetri dan Ginekologi, Divisi Fertilitas Endokrinologi Reproduksi, Fakultas Kedokteran Universitas Sumatera Utara Medan, Indonesia

Tujuan: Untuk mengetahui tingkat keberhasilan preparasi sperma metode swim-up dengan densitas gradien pada inseminasi intrauterin.

Metode: Penelitian analitik komparatif dilakukan di Klinik Fertilitas Halim, Rumah Sakit Ibu dan Anak Stella Maris Medan, Divisi Fertilitas Endokrinologi, dan Reproduksi Fakultas Kedokteran Universitas Sumatera Utara. Sebanyak delapan puluh pasangan infertil dibagi secara acak ke dalam dua kelompok berdasarkan metode preparasi sperma yang digunakan pada IUI yaitu swim up atau densitas gradien. Dilakukan evaluasi terhadap progresifitas sperma, total sperma motil, kehamilan biokimiawi dan kehamilan klinis.

Hasil: Rerata peningkatan persentase sperma progresif cepat dijumpai lebih tinggi secara signifikan ( $<<0,05)$ pada kelompok densitas gradien dibandingkan kelompok swim up $(19,02 \pm 16,19$ dan 11,78 $\pm 13,71)$. Rerata peningkatan persentase total sperma motil lebih baik pada kelompok densitas gradien dibandingkan kelompok swim up $(2,53 \pm 1,41$ dan $2,39 \pm 1,06)$ namun tidak signifikan $(\mathrm{p}>0,05)$. Kehamilan biokimiawi dan kehamilan klinis lebih tinggi pada kelompok densitas gradien $(27,5 \%$ dan $22,5 \%)$ dibandingkan kelompok swim up $(25 \%$ dan $17,5 \%)$ namun tidak signifikan $(\mathrm{p}>0,05)$.

Kesimpulan: Preparasi sperma dengan metode densitas gradien memberikan hasil yang lebih baik dari segi peningkatan sperma progresif cepat, namun tidak ditemukan perbedaan signifikan pada kehamilan biokimia dan kehamilan klinis antara kedua kelompok metode preparasi sperma.

Kata kunci: Inseminasi intrauterin, preparasi sperma, swim up, densitas gradien.

\section{TEMUAN LAPAROSKOPI ADENOMIOSIS TERINFEKSI}

Hesti Nurmala Rizqi ${ }^{1}$, Setyo Hermanto ${ }^{2}$

${ }^{1}$ Departemen Obstetri dan Ginekologi, Rumah Sakit Umum Pusat Nasional Cipto Mangunkusumo, Fakultas Kedokteran Universitas Indonesia, ${ }^{2}$ SMF Obstetri dan Ginekologi, Rumah Sakit Umum Pusat Fatmawati

Latar belakang: Adenomiosis merupakan kelainan ginekologi yang ditemukan pada $25 \%$ dari seluruh spesimen uterus pasca histerektomi. Patogenesis terjadinya adenomiosis masih menjadi pertanyaan bagi banyak peneliti, namun teori yang umum diterima adalah invaginasi lapisan basalis endometrium ke dalam 
miometrium. Adenomioma kistik merupakan salah satu bentuk adenomiosis dengan gambaran hipoekoik pada imaging yang diduga merupakan gambaran bekuan darah yang dikelilingi miometrium. Namun pada kondisi yang jarang, adenomioma kistik bukan berisi darah, namun cairan abses dengan patogenesis diduga serupa dengan kista endometriosis terinfeksi.

Kasus: Pada kasus, seorang wanita 45 tahun dengan benjolan pada abdomen hingga 2 jari di atas umbilikus, datang dengan nyeri haid. Nyeri kemudian dirasakan diluar haid sejak 1 minggu sebelum dilakukan operasi. Pasien tidak mempunyai gejala dan tanda infeksi lainnya seperti demam dan leukositosis. Pada pemeriksaan MRI didapatkan gambaran adenomiosis dengan multipel kistik. Pasien kemudian dilakukan total laparoscopic hysterectomy (TLH) dan salpingoooforektomi bilateral. Temuan intraoperatif didapatkan miometrium berisi pus yang keluar saat spesimen uterus dilakukan morselasi. Kista endometriosis bilateral juga ditemukan pada pasien namun tanpa tanda infeksi yang tampak. Pemeriksaan diagnostik gold standard histopatologi menunjukkan spesimen uterus dengan jaringan adenomiosis disertai abses yang mengkonfirmasi diagnosis adenomiosis terinfeksi. Pasien kemudian dirawat selama 3 hari dengan pemberian antibiotik intravena dan dipulangkan dalam kondisi baik.

Diskusi: Penegakan diagnosis dan tatalaksana pasien dengan adenomiosis terinfeksi berbeda dengan adenomiosis tanpa komplikasi. Laporan kasus pyoadenomiosis sebelumnya yang diberikan antibiotik sebelum tidak menunjukkan respons yang baik. Pada kasus ini antibiotik baru diberikan setelah tindakan histerektomi menjadi pilihan lainnya dalam tatalaksana adenomiosis terinfeksi.

Kesimpulan: Adenomiosis terinfeksi jarang ditemukan sehari-hari, sehingga perlu dikembangkan metode diagnosis dan tatalaksana yang paling efektif bagi pasien.

Kata kunci: Adenomiosis terinfeksi, pyoadenomyosis, laparoskopi.

\section{KORELASI KADAR OSTEOCALCIN URIN TERHADAP DENSITAS MASSA TULANG PADA WANITA MENOPAUSE DI RSUP H. ADAM MALIK MEDAN}

Dwi Fenny Amir, M. Fidel Ganis Siregar, Deri Edianto, Christoffel L. Tobing, M. Fahdhy, Cut Adeya Adella

Departemen Obstetri dan Ginekologi, Fakultas Kedokteran Universitas Sumatera Utara, RSUP H. Adam Malik Medan
Latar belakang: Angka kejadian osteoporosis pada wanita menopause di seluruh dunia masih tinggi, dan diperkirakan akan semakin meningkat. Menurut WHO, 30\% wanita menopause akan mengalami osteoporosis. Menurut data SIRS tahun 2010, insidensi patah tulang sekitar 200/100.000 kasus pada wanita menopause akibat osteoporosis. Sebagai tindakan preventif, diperlukan suatu pemeriksaan untuk mendiagnosis osteoporosis yang noninvasif, mudah, dan murah. Kadar osteocalcin akan meningkat sehubungan dengan penurunan densitas massa tulang. Sehingga, osteocalcin urin dapat digunakan untuk diagnosis osteoporosis pada wanita menopause.

Tujuan: Penelitian ini diharapkan dapat mengetahui korelasi antara osteocalcin urin dengan densitas tulang pada wanita menopause.

Metode: Penelitian deskriptif dengan rancangan case series yang dilakukan di Departemen Obstetri dan Ginekologi RSUP H. Adam Malik Medan dan Laboratorium Terpadu Fakultas Kedokteran Universitas Sumatera Utara dan RS. Setia Budi untuk pengukuran DEXA Scan pada bulan Januari 2019. Sampel penelitian diambil sejumlah 21 orang wanita menopause dengan menggunakan non-probability sampling dengan teknik consecutive sampling. Analisa hubungan osteocalcin urin dengan densitas tulang menggunakan korelasi Pearson.

Hasil: Nilai rerata osteocalcin urin pada wanita dengan densitas massa tulang yang normal adalah 6,67 $\pm 0,53$, nilai rerata untuk kelompok wanita osteopenia adalah 9,05 $\pm 1,30$. Hasil korelasi Pearson menunjukkan skor $\mathrm{r}-0,8203$ dan $\mathrm{p}<0,001$. Hal ini menunjukkan bahwa semakin tinggi kadar osteocalcin urin, semakin rendah skor $\mathrm{T}$ pada penelitian ini.

Kesimpulan: Menunjukkan korelasi negatif signifikan yang sangat kuat antara kadar osteocalcin urin dengan densitas tulang (Skor T) pada wanita menopause

Kata kunci: Osteocalcin, densitas massa tulang, menopause.

\section{UJI KLINIK TERKONTROL TERBUKA PERBANDINGAN EFFICACY, SAFETY DAN ACCEPTABILITY ANTARA SUNTIKAN KB, ESTRADIOL SIPIONAT 7,5 MGRAM DENGAN MPA 25 MGRAM (GESTIN F2(R DAN ESTRADIOL SIPIONAT (ES) 5 MGRAM (CYCLOFEM (R) )}

Muhar Yunan Tanjung ${ }^{1}$,Delfi Lutan ${ }^{1}$, Ichwanul Adenin $^{1}$, Herri S Sastramihardja ${ }^{2}$, Kuswinarti ${ }^{2}$, Taufiqurrahman Rahim ${ }^{3}$, Mira Yustiawati ${ }^{3}$, Maftachah Rochmanti ${ }^{4}$, Ashon Sa'adi ${ }^{4}$, Retno Budiarti Farid ${ }^{5}$, Monica Fitria Farid 
${ }^{I}$ Departemen Obstetri dan Ginecologi. Fakultas Kedokteran, Universitas Sumatera Utara, Medan. ${ }^{2}$ Departemen Farmakologi dan Therapi. Fakulas Kedokteran, Universitas Padjadjaran, Bandung. ${ }^{3}$ Departemen Obstetri dan Ginecologi. Fakulas Kedokteran, Universitas Lampung, Lampung. ${ }^{4}$ Departemen Farmacologi. Fakultas Kedokteran, Universitas Airlangga, Surabaya.

${ }^{5}$ Departemen Obstetri dan Ginecologi. Fakultas Kedokteran, Universitas Hasanudin, Makassar

Tujuan: Untuk mengetahui efficacy, safety and acceptability dari kontrasepsi suntikan dengan menggunakan estradiol sipionat 7,5 mg (Gestin F2(R)) dan kontrasepsi suntikan MPA $25 \mathrm{mg}$ dengan estradiol sipionat (ES) $5 \mathrm{mg}$ (Cyclofem (R) ). Hasil utamanya mengetahui kepuasan peserta. .

Metode: 22 bulan Phase III penelitian, yang dilakukan pada multisenter penelitian pada 5 senters dengan 359 and 360, total 719 subjek pada masa penelitian 24 bulan. Wanita ingin menunda atau menjarangkan kelahiran dilokasi penelitian, 18-40 tahun, dengan siklus menstruasi yang normal (21-35 hari), menginginkan kontrasepsi Gestin F2 atau Cyclofem OC. Diikuti keluhan, flour albus, sakit kepada sakit dada, perdarahan pervaginam tak teratur dan perubahan berat badan. Serta alasan penghentian pemakaian kontrasepsi. Penelitian adalah Random Uji Klini terkontrol label yang terbuka permuted block randomization method dari kelompok yang menerima injeksi Gestin F2 dibandingkan dengan injeksi Cyclofem. Data dianalisa dengan metoda statistik.

Hasil: Efek samping dari Gestin F2, dibandingkan dengan Cyclofem, setelah dua belas bulan pemakaian $13(3.80 \%)$ peserta dan $3(0.90 \%)$ peserta . Problem yang terutama adalah Flour albus. Injeksi kontrasepsi dapat dikatakan efektif untuk 12 bulan pemakaian, dengan angka kegagagan $(0.1 \%)$. Penerimaan injeksi Gestin F-2 were 87 per 100 wanita; dan cyclofem injeksi 85per 100 wanita.

Kesimpulan: Efek samping yang terutama adalah flour albus.tidaka dijumpai efekyang tidak diinginkan dari subjek. Kejadian yang tidak diinginkan dalam batas normal yang tidak memerlukan interfensi untuk aktifitas kesehatan. Gestin F2 dan Cyclofem keduanya dapat dihubungkan dengan banyak peserta yang puas dan toleransi yang baik.

Kata kunci: kontrasepsi injeksi, gestin F2, cyclofem, efek samping.

\section{ULTRASONOGRAFI GENITALIA INTERNA PADA MAHASISWI DENGAN DISMENORE PRIMER}

Adi Sukrisno $^{1}$, Fiorentina Wahyutama ${ }^{2}$

${ }^{1}$ Departemen Obstetri \& Ginekologi FK UPN Veteran Jakarta

${ }^{2}$ Program Studi Pendidikan Dokter FK UPN Veteran Jakarta

Latar belakang: Dismenore merupakan gangguan ginekologi yang paling umum terjadi pada perempuan. $10-25 \%$ diantara perempuan usia reproduktif mengalami dismenore primer berat.

Tujuan: Tujuan penelitian ini adalah mengetahui pengaruh posisi uterus, volume uterus, dan ukuran ovarium terhadap kejadian dismenore primer pada mahasiswi Fakultas Kedokteran Universitas Pembangunan Nasional "Veteran" Jakarta.

Metode: Penelitian ini menggunakan desain penelitian analitik observasional dengan pendekatan potong lintang. Sebanyak 66 mahasiswi Fakultas Kedokteran Universitas Pembangunan Nasional "Veteran" Jakarta digunakan sebagai sampel pada penelitian ini. Pengambilan sampel dilakukan menggunakan metode Stratified Random Sampling. Data diperoleh melalui kuesioner dan hasil pemeriksaan ultrasonografi 2-Dimensi terhadap subjek.

Hasil: Mayoritas subjek berusia 18 tahun (25,8\%), mengalami dismenore $(78,8 \%)$, mengalami nyeri ringan $(33,3 \%)$, dan memiliki riwayat keluarga dengan dismenore $(53,0 \%)$. Mayoritas subjek memiliki posisi uterus antefleksi-anteversi $(63.6 \%)$, volume uterus lebih dari normal $(72,7 \%)$, dan ukuran ovarium normal $(89,4 \%)$. Berdasarkan uji Chi-Square dan uji regresi logistik, posisi uterus (OR 0,207) dan volume uterus (OR 9,167) memiliki hubungan yang signifikan dengan kejadian dismenore primer sedangkan ukuran ovarium tidak berhubungan dengan kejadian dismenore primer.

Kesimpulan: Dengan demikian, volume uterus menjadi faktor yang paling mempengaruhi terjadinya dismenore primer pada mahasiswi Fakultas Kedokteran Universitas Pembangunan Nasional "Veteran" Jakarta.

Kata kunci: Dismenore primer, posisi uterus, volume uterus.

\section{FETOMATERNAL}

STRATEGI PENCEGAHAN KELAHIRAN
PRETERM: PENGARUH PEMBERIAN VITAMIN
D3 TERHADAP EKSPRESI GEN
CORTICOTROPHIN RELEASING HORMONE
(CRH), CORTICOTROPHIN RELEASING




\section{HORMONE-RECEPTOR 1 (CRH-R1), DAN CONNEXIN-43 (CON-43) PADA PROFIL REGULASI KONTRAKTILITAS SEL LINI PHM1-41 YANG MENGALAMI STRES OKSIDATIF}

\author{
M. Alamsyah Aziz, Sofie R Krisnadi, ${ }^{1}$ Budi \\ Setiabudiawan, ${ }^{2}$ Budi Handono ${ }^{1}$
}

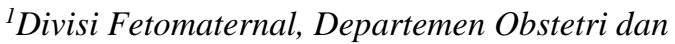
Ginekologi, Fakultas Kedokteran Universitas Padjadjaran/Rumah Sakit dr. Hasan Sadikin Bandung, Indonesia. ${ }^{2}$ Departemen Kesehatan Anak, Fakultas Kedokteran Universitas Padjadjaran/Rumah Sakit dr. Hasan Sadikin Bandung, Indonesia.

Latar Belakang: Kelahiran preterm merupakan salah satu penyebab kematian neonatal yang masih menjadi permasalahan di seluruh dunia. Data WHO menunjukkan bahwa Indonesia memiliki rasio kelahiran preterm yang masih cukup tinggi sebesar $15,5 \%$ per 100 kelahiran hidup. Data Maternal Perinatal Registrasi Indonesia yang terkumpul dari 11 rumah sakit di Jawa Barat, didapatkan insiden persalinan preterm sebesar $15,82 \%$. Salah satu mekanisme patofisiologis yang menyebabkan terjadinya kelahiran preterm adalah aktivitas sumbu Hipotalamus-Pituitari-Adrenal (HPA). Stres maternal biologis berupa kondisi hipoksia merupakan penyebab terjadinya kelahiran preterm melalui jalur aktivasi sumbu HPA. Kondisi stres ini mengakibatkan aktivasi sumbu HPA dan meningkatkan CRH, CRH-R1, dan CON-43 sebagai pemicu terjadinya proses kontraksi. Vitamin $\mathrm{D}_{3}$ sebagai sumber ion $\mathrm{Ca}^{2+}$ dan antioksidan dibutuhkan untuk mekanisme kontraksi dan relaksasi otot halus miometrium.

Tujuan: Tujuan penelitian ini adalah menganalisis hubungan penambahan vitamin $\mathrm{D}_{3}$ dengan kadar ROS, ekspresi gen CRH, CRH-R1, dan CON-43 pada sel lini PHM1-41 dalam kondisi stres oksidatif.

Metode: Penelitian ini merupakan penelitian eksperimental menggunakan sel lini otot halus miometrium uterus manusia PHM1-41 sebagai model in vitro yang diberi perlakuan stres oksidatif hipoksia dan penambahan vitamin $\mathrm{D}_{3}(5,10,50$ dan $150 \mathrm{nM})$. Dilakukan uji viabilitas untuk toksisitas vitamin $\mathrm{D}_{3}$ terhadap sel yang akan diuji. Sel PHM1-41 yang telah dikultur dalam keadaan hipoksia selama 24 jam diberi penambahan vitamin $\mathrm{D}_{3}$, kemudian diukur kadar ROS menggunakan DCFDA fluoresen. Selain itu, RNA sel diisolasi kemudian dianalisis ekspresi gen yang diperiksa sebagai profil regulasi kontraktilitas.

Hasil: Hasil menunjukkan kadar ROS turun dari $19,49 \pm 1,76 \%$ menjadi $7,16 \pm 0,23 \%$ dan ekspresi seluruh gen lebih rendah pada kelompok yang diberi penambahan vitamin $\mathrm{D}_{3} \quad 150 \mathrm{nM}$ dibandingkan kelompok kontrol hipoksia. Hasil korelasi Pearson menunjukkan hubungan negatif antara penambahan vitamin $\mathrm{D}_{3}$ dengan rendahnya kadar ROS, ekspresi gen $\mathrm{CRH}$, ekspresi gen CRH-R1, dan ekspresi gen CON-43 pada sel lini PHM1-41 dalam kondisi stres oksidatif. Simpulan bahwa vitamin $\mathrm{D}_{3}$ memiliki potensi dalam mencegah kelahiran preterm.

Kata kunci: CRH, CRH-R1, CON-43, hipoksia, Vitamin $\mathrm{D}_{3}$

\section{PERSALINAN IBU HAMIL DENGAN OBESITAS DI RSUD DR. SOETOMO SURABAYA TAHUN $2017-2018$}

Amirah $^{1}$, Khanisyah Erza Gumilar ${ }^{2}$

${ }^{1}$ PPDS1 Departemen/SMF Obstetri dan Ginekologi RSUD Dr. Soetomo, Fakultas Kedokteran Universitas Airlangga Surabaya, ${ }^{2}$ Staf Pengajar Departemen/ SMF Obstetri dan Ginekologi RSUD Dr. Soetomo, Fakultas Kedokteran Universitas Airlangga Surabaya

Latar Belakang: Obesitas merupakan suatu kondisi akumulasi lemak tubuh yang berlebihan yang dapat membahayakan seseorang dan dianggap sebagai faktor risiko kelima untuk kematian global. Menururut Riset Kesehatan Dasar (Riskesdas) di Indonesia tahun 2018, tingkat obesitas orang dewasa di Indonesia meningkat menjadi $21,8 \%$. Prevelensi ini meningkat dari hasil Riskesdas tahun 2013 yang menyebut bahwa angka obesitas di Indonesia hanya mencapai $14,18 \%$.

Tujuan: Melihat komplikasi dari persalinan ibu hamil dengan obesitas di RSUD Dr Soetomo yang merupakan Rumah Sakit terbesar di Indonesia dan pusat rujukan Indonesia Timur.

Metode: Studi ini merupakan studi deskriptif retrospektif. Kasus Persalinan Ibu Hamil dengan obesitas di RSUD Dr. Soetomo pada bulan Januari 2017- Desember 2018. Data pada studi ini diperoleh melalui data register di VK Bersalin dan Poli Hamil RSUD Dr.Soetomo.

Hasil: Angka kejadian Persalinan ibu hamil dengan Obesitas di RSUD Dr. Soetomo Surabaya tahun 2017 - 2018 sebanyak 612 Kasus dari 2763 persalinan (22\%), mayoritas penderita berusia 20-34 tahun dan wanita multipara (70\%). Faktor Komorbid terbesar adalah Preeklampsia (82\%), Diabetes gestasional (10\%), Macrosomia (5\%), dan Kelainan kongenital (3\%). Persalinan Perabdominam terjadi pada mayoritas kasus Obesitas. Terdapat 3 kasus kematian pada persalinan ibu hamil dengan obesitas.

Kesimpulan: Mayoritas ibu hamil dengan Obesitas yang melahirkan di RSUD Dr. Soetomo tahun 2017 - 2018 adalah wanita multipara berusia 22-34 tahun dengan faktor komorbid terbanyak Preeklampsia, DM Gestasional, Macrosomia, dan Kelainan Kon- 
genital. Mayoritas penderita menjalani persalinan perabdominam.Terdapat 3 kasus kematian pada persalinan ibu hamil dengan obesitas.

Kata Kunci: Obesitas, Hamil, Persalinan

\section{TEMUAN PLASENTA AKRETA INSIDENTAL DAN TATALAKSANA DI DAERAH TERPENCIL: SEBUAH LAPORAN KASUS}

\author{
Putri A, ${ }^{1}$ Wahono WT, ${ }^{1}$ Saroyo $\mathrm{YB},{ }^{2}$ Nugroho AJ, ${ }^{1}$ \\ Marjono $\mathrm{B}^{3}$
}

${ }^{I}$ RSUD Puruk Cahu, Kalimantan Tengah

${ }^{2}$ Departemen Obstetri dan Ginekologi, Universitas

Indonesia, Jakarta, ${ }^{3}$ RS Medistra, Jakarta

Latar belakang: Plasenta akreta merupakan suatu kondisi dimana plasenta melekat pada miometrium secara patologis dan dapat menyebabkan komplikasi berbahaya termasuk perdarahan post-partum yang hebat. Salah satu hipotesis menyatakan bahwa penyebabnya adalah defek dari lapisan antara endometriummiometrium sehingga desidualisasi pada area bekas luka pada uterus menjadi abnormal. Evaluasi melalui ultrasonografi merupakan hal yang penting. Pada kasus tidak tersedianya evaluasi ultrasonografi, faktor risiko klinis dapat membantu prediksi plasenta akreta, seperti riwayat persalinan sesar sebelumnya. Insiden plasenta akreta pada wanita tanpa riwayat persalinan sesar sebelumnya sebesar $0.24 \%$ dan meningkat mencapai $3 \%$ bila disertai dengan plasenta previa.

Tujuan: Deskripsi diagnosis dan tatalaksana temuan insidental kasus plasenta akreta dalam keterbatasan di daerah terpencil

Kasus: Wanita 39 tahun, P5, dengan syok hipovolemik karena perdarahan postpartum et causa retensio plasenta pada persalinan spontan pervaginam yang dibantu dukun kampung. Tidak didapatkan riwayat sesar atau kuretase sebelumnya dan tidak pernah melakukan antenatal care. Resusitasi cairan dan transfusi darah diberikan bersamaan dengan manual plasenta, dimana plasenta sulit untuk dipisahkan dari dinding uterus dan tercabik saat dikeluarkan. Diputuskan untuk dilakukan laparotomi dan dilanjutkan dengan histerektomi subtotal untuk menghentikan perdarahan. Hasil histopatologi didapatkan adanya sel trophoblast hingga lapisan myometrium, sesuai dengan plasenta akreta. Kasus ini merupakan kasus plasenta akreta tanda riwayat operasi ataupun kuretase sebelumnya, dengan temuan insidental pada kasus retensio plasenta.

Kesimpulan: Pada kasus ini tidak adanya riwayat sesar dan kuretase sebelumnya ataupun plasenta previa tidak menyingkirkan kemungkinan terjadinya plasenta akreta. Diagnosis dan tatalaksana yang tepat pada fasilitas terbatas dibutuhkan untuk menghentikan perdarahan dan menyelamatkan ibu.

Kata kunci: plasenta akreta, dukun kampung, perdarahan postpartum, retensio plasenta

\section{PERBANDINGAN EFEKTIFITAS PEMBERIAN TOKOLITIK NIFEDIPIN DAN ISOKSUPRIN TERHADAP KONTRAKSI UTERUS PADA KEJADIAN ANCAMAN PERSALINAN PRETERM DI RUMAH SAKIT HASAN SADIKIN BANDUNG}

Herry Aktyar Matondang

\section{Fakultas Kedokteran Universitas Padjadja ran, RSUP Dr. Hasan Sadikin Bandung}

Latar Belakang: Persalinan preterm masih menjadi masalah utama di bidang obstetri karena mengakibatkan angka mortalitas dan morbiditas neonatal yang tinggi. Salah satu upaya pencegahan persalinan preterm yaitu dengan pemberian tokolitik untuk memberikan kesempatan pemberian kortikosteroid sebagai obat pematangan paru. Nifedipin dan isoksuprin merupakan tokolitik yang keduanya efektif tetapi protokol pemberiannya diberbagai senter masih bervariasi. Penelitian ini bertujuan untuk mengetahui perbedaan perubahan frekuensi dan kekuatan uterus antara pemberian nifedipin dengan isoksuprin.

Metode: Penelitian ini merupakan penelitian randomized controlled trial (RCT) dengan metode randomisasi double blind. Subjek penelitian adalah wanita hamil yang memenuhi kriteria penelitian $(n=16)$. Perlakuan diberikan selama 48 jam. Parameter yang diukur yaitu frekuensi dan kekuatan kontraksi sebelum dan sesudah pemberian terapi tokolitik nifedipin dan isoksuprin. Penelitian dilakukan di RSUP Dr. Hasan Sadikin pada bulan Januari sampai dengan Maret 2019.

Hasil: Hasil penelitian menunjukkan terdapat penurunan frekuensi dan kekuatan kontraksi uterus lebih besar setelah pemberian tokolitik isoksuprin selama 48 jam dibandingkan dengan tokolitik nifedipin dan signifikan secara statistik dengan nilai p 0,0001 ( $\mathrm{p}<0,05)$ menggunakan uji Mann Whitney.

Kesimpulan: Pemberian tokolotik isoksuprin lebih efektif untuk menurunkan frekuensi dan kontraksi uterus dibandingkan dengan nifedipin terhadap ancaman persalinan preterm.

Kata kunci: Nifedipin, Isoksuprin, Frekuensi dan kekuatan kontraksi, Ancaman persalinan preterm 


\section{PENGGUNAAN TAMPON EKSTERNAL UTERUS SEBAGAI ALTERNATIF PERTOLONGAN PERTAMA MANAJEMEN PERDARAHAN PASCASALIN DENGAN SUMBER DAYA TERBATAS}

Qonita Prasta Agustia, Arifian Juari, Pande Made Dwijayasa

\section{RSIA Puri Bunda Kota Malang}

Latar Belakang. Perdarahan pasca-salin (PPS) merupakan penyebab kematian langsung maternal terutama di negara berkembang. Modalitas terapi yang digunakan pada kasus PPS yang gagal dengan pemberian uterotonika adalah dengan pemasangan tampon balon kateter yang telah terbukti efektif. Akan tetapi, tindakan ini memerlukan keahlian dan pengalaman khusus. Dibutuhkan alternatif tindakan pertolongan pertama yang mudah dan efektif serta dapat dilakukan oleh semua tenaga kesehatan tanpa pengalaman dan keahlian khusus. Salah satunya adalah dengan menggunakan tampon eksternal uterus, yaitu melakukan pemasangan 'sabuk' benda padat untuk menahan fundus uteri setinggi umbilikus, serta menahan bagian bawah uterus melalui pemasangan tampon kassa padat di dalam vagina. Dengan demikian uterus 'terjepit', sehingga tidak dapat membesar dan terisi darah. Penulis melaporkan pengalaman beberapa kasus PPS yang diatasi dengan menggunakan pemasangan tampon eksternal uterus.

Tujuan: Penelitian ini bertujuan untuk melaporkan kasus penggunaan tampon eksternal uterus sebagai alternatif pertolongan pertama dalam manajemen PPS.

Metode: Penelitian ini merupakan penelitian deskriptif dengan pendekatan serial kasus yang dilaksanakan di RSIA Puri Bunda, Kota Malang. Data diambil dari rekam medis pasien pada periode Januari 2019 - Maret 2019. Pada penelitian ini, sampel diambil dengan teknik consecutive sampling.

Hasil: Pada penelitian ini ditemukan sebanyak 6 kasus PPS dimana tampon eksternal uterus ini berhasil menghentikan perdarahan pada keseluruhan kasus $(100 \%)$ dengan rerata waktu lama penggunaan adalah 85 menit $\mathrm{SD} \pm 39,8$ pada keseluruhan kasus tanpa menimbulkan komplikasi seperti syok ataupun intervensi lanjut seperti operasi. Tatalaksana transfusi pasca perdarahan hanya terjadi pada 1 kasus $(16,6 \%)$ dikarenakan $\mathrm{Hb}$ awal pasien yang rendah $(9,6 \mathrm{gr} / \mathrm{dL})$.

Kesimpulan: Penggunaan tampon eksternal uterus ini dapat menjadi alternatif modalitas awal yang mudah pada penanganan pertama PPS. Dibutuhkan penelitian lebih lanjut dengan jumlah sampel yang lebih besar untuk mengetahui efektivitas penggunaan tampon eksternal uterus ini.
Kata Kunci: PPS, tampon eksternal uterus

\section{DETERMINAN LUARAN BAYI BERAT LAHIR RENDAH PADA WANITA DENGAN KETUBAN PECAH DINI}

Sarah Chairani Zakirah ${ }^{1,3,4^{*}}$, Putri Chairani Eyanoer ${ }^{5}$, Dina Fadilla ${ }^{4}$, Budi Wiweko ${ }^{1,2,3}$

${ }^{1}$ Divisi Fertilitas Endokrinologi dan Reproduksi, Departemen Obstetri and Ginekologi, Fakultas Kedokteran, Universitas Indonesia, Jakarta, 10430, Indonesia, ${ }^{2}$ Klinik Yasmin IVF, RSUP Dr. Cipto Mangunkusumo, Jakarta, 10430, Indonesia. ${ }^{3}$ Klaster Human Reproductive, Infertility and Family Planning Research Center, Indonesia Medical Education and Research Institute(IMERI), Fakultas Kedokteran, Universitas Indonesia, Jakarta, 10430, Indonesia. ${ }^{4}$ Fakultas Kedokteran, Universitas Sumatera Utara, Medan, Indonesia. ${ }^{5}$ Departemen Kedokteran Komunitas, Fakultas Kedokteran, Universitas Sumatera Utara, Medan, Indonesia

*Korespondensi: sarahchairani@gmail.com

Latar Belakang: Berbagai faktor dikatakan sebagai risiko terkait BBLR.

Tujuan: Penelitian ini bertujuan untuk mengevaluasi faktor risiko antenatal yang berperan terhadap luaran BBLR pada wanita usia reproduktif yang mengalami KPD.

Metode: Penelitian ini merupakan penelitian observasional analitik dengan desain penelitian crosssectional, dimana mengkaji hubungan antara beberapa faktor risiko terkait kejadian BBLR pada wanita dengan PROM. Sampel diambil dengan menggunakan cara consecutive sampling dari tanggal 22 April 2018 hingga 15 Mei 2018 di Instalasi Rekam Medis Rumah Sakit Umum Kertha Usada, Buleleng, Bali. Data yang digunakan pada penelitian ini adalah data nonparametrik yaitu berupa data nominal dan ordinal dengan analisis data menggunakan uji Chi-Square atau Kruskal-Wallis jika data tidak memenuhi syarat.

Hasil: Pada penelitian ini, terdapat jumlah responden PROM dan PPROM sebanyak 260 orang, dimana 48 orang tidak memenuhi kriteria, sehingga terdapat 212 orang yang memenuhi kriteria. Dari 212 orang diklasifikasikan menjadi 3 kelompok, yakni BBLN, BBLB, BBLR. Responden BBLN sebanyak 200 bayi (94.3\%), BBLB sebanyak 6 bayi (2.8\%), BBLR sebanyak 6 bayi $(2.8 \%)$. Data menunjukkan bahwa terdapat hubungan yang signifikan antara variable usia kehamilan $(\mathrm{p}<0.01)$ dan NLR $(\mathrm{p}=0.048)$ dengan bayi berat lahir rendah (BBLR). 
Kesimpulan: Kecilnya usia kehamilan dan tingginya NLR dapat digunakan sebagai prediktor faktor risiko luaran BBLR. Penelitian dengan sampel yang lebih besar dan pemerataan jumlah sampel dengan BBLB dan BBLR dibutuhkan mengingat penelitian ini responden terbanyak berasal dari kelompok BBLN.

Kata Kunci: BBLR, KPD, Faktor Risiko

\section{ANALISIS KOMPARASI DIAGNOSIS GAWAT JANIN BERDASARAKAN GAMBARAN KTG KATEGORI 3 (NICHHD) DENGAN PENILAIAN MAEDA DI RSUP SANGLAH DENPASAR PERIODE 1 JANUARI 2015 - 31 DESEMBER 2016}

Mervinna Giovanni, AAN Jaya Kusuma, I Wayan Artana Putra, AA Putra Wiratnyana, I Wayan Megadhana

Divisi Fetomaternal SMF/Bagian Obstetri dan Ginekologi RSUP Sanglah/Universitas Udayana, Bali, Indonesia

Latar Belakang: Diagnosis Gawat Janin selama persalinan sangatlah penting, Kardiotokografi (KTG) merupakan alat pantau yang paling lazim digunakan, namun metode ini memiliki spesitifitas yang rendah sehingga pada pengunaannya mengakibatkan meningkatnya angka persalinan secara operatif, tanpa menurunkan mortalitas perinatal.

Metode: Pada penelitian deskriptif ini kami akan mecari perbandingan KTG Kategori 3 dengan penilaian MAEDA pada keluaran pada bayi, yang dilakukan di RSUP Sanglah pada periode 1 Januari 2015-31 Desember 2016.

Hasil: Sampel penelitian sebanyak 11 gambaran KTG Kategori 3 yang dilakukan SC yang didapatkan dengan keluaran bayi, $81,8 \%$ memiliki nilai APGAR $<7$, dan 90\% mengalami asiodosis dilihat dari $\mathrm{pH}$ analisis gas darah umbilikal. Dari KTG Kategori 3 yang dilakukan penilaian MAEDA, 54,5\% didapatkan dengan nilai $>15$. Pada nilai MAEDA $>15$ semuanya didapatkan dengan APGAR $<7$, dan $\mathrm{pH}$ analisis gas darah umbilikal $<7,2$. Pada penelitian ini didapatkan sensitifitas dari Penilaian MAEDA pada gawat janin dengan gambaran KTG Kategori 3 adalah 88,9\%, dan spesitifitas sebesar $50 \%$.

Kata Kunci: Kardiotokografi, Kategori 3, Penilaian MAEDA, Gawat Janin.

LUARAN MATERNAL DAN NEONATAL PADA PREEKLAMPSIA BERAT EARLY ONSET DAN

\section{LATE ONSET DI RSUD DR. SOETOMO SURABAYA TAHUN 2017-2018}

Nila Krisna Sari, Nareswari Cininta

Departemen Obstetri dan Ginekologi, Fakultas

Kedokteran, Universitas Airlangga, RSUD Dr Soetomo, Surabaya

Tujuan: Memperoleh gambaran faktor-faktor yang berhubungan dengan luaran maternal dan neonatal pasien preeklampsia berat Early onset dan Late onset di Rumah sakit dr. Soetomo tahun 2017-2018

Metode: Deskriptif retrospektif menggunakan data sekunder register kamar bersalin, buku perinatologi, rekam medis, laporan pagi Rumah Sakit Dr. Soetomo mulai Januari 2017 sampai dengan Desember 2018. Kriteria inklusi: pasien preeklampsia berat yang lahir di Rumah Sakit Dr. Soetomo surabaya tahun 2017-2018. Kriteria eksklusi: pasien preeklampsia berat yang melahirkan di luar Rumah Sakit Dr. Soetomo, pasien dengan hipertensi kronis.

Hasil: Angka kejadian preeklampsia berat di RSUD Dr. Soetomo Surabaya tahun 2017 - 2018 sebanyak 550 kasus dari 2763 persalinan (19,9\%). Didapatkan kasus late onset sebanyak $55 \%$ early onset $45 \%$, mayoritas kasus rujukan sebanyak $84,5 \%$, berusia 17-34 th sebanyak 59\%, multigravida $72 \%$, obesitas kelas I 29\%. Indikasi terminasi karena faktor janin adalah pertumbuhan janin terhambat $45 \%$, fetal distress $19 \%$, sedangkan dari faktor ibu adalah edema paru $35 \%$, sindroma HELLP $32 \%$, impending eklampsia $26 \%$. Metode persalinan dengan seksio sesarea $71 \%$, ekstraksi forsep $13 \%$. Luaran neonatus pada early onset terbanyak dengan berat $<1500 \mathrm{~g}$ sebanyak $53,1 \%$, skor apgar 4-6 $36,7 \%$, sedangkan pada late onset terbanyak dengan berat>3000 g sebanyak 28,5\% dan skor apgar 7-10 $66,3 \%$. Angka kematian maternal sebanyak 2,3\%, kematian neonatal sebanyak $13,5 \%$ dan kematian janin dalam rahim 7,2\%.

Kesimpulan: Angka kejadian late onset lebih banyak daripada early onset. Pada kasus early onset maupun late onset terbanyak adalah kasus rujukan, usia 17-34 th, multigravida, obesitas kelas I. Indikasi terminasi pada kasus early onset maupun late onset terbanyak adalah pertumbuhan janin terhambat dan edema paru.

Kata Kunci: preeklampsia berat, early onset, late onset 


\section{PREEKLAMSIA KOMPLIKASI DAN PREEKLAMSIA TANPA KOMPLIKASI}

Noroyono Wibowo, Rima Irwinda, Andri Welly

Departemen Obstetri dan Ginekologi - Divisi Fetomaternal, Rumah Sakit Umum Pusat Nasional Cipto Mangunkusumo, Jakarta, Indonesia

Latar belakang: Preeklamsia merupakan suatu sindrom spesifik kehamilan, yang berkontribusi terhadap tingginya angka kesakitan dan kematian maternal dan perinatal, serta berhubungan dengan risiko jangka panjang untuk kemudian hari. Sehingga dibutuhkan suatu pemantauan dari parameter-parameter klinis dan laboratorium pada preeklamsia saat 6 minggu pasca salin untuk menilai perbaikan, ataupun progesifitas dari suatu kehamilan dengan preeklamsia.

Tujuan: Mengetahui tekanan darah sistolik, tekanan darah diastolik dan mean arterial pressure (MAP), hemoglobin, hematokrit, trombositopenia, proteinuria kualitatif, gula darah puasa, asam urat, $\mathrm{LDH}$, SGOT, SGPT, ureum dan kreatinin pada saat persalinan dan saat 6 minggu pasca salin pada kelompok preeklamsia tanpa komplikasi dan kelompok preeklamsia dengan komplikasi.

Metode: Desain kohort prospektif dengan metode analisis pengukuran berulang parameter-parameter klinis dan laboratorium pada kelompok preeklamsia tanpa komplikasi dan preeklamsia dengan komplikasi.

Hasil: Didapatkan perbedaan hasil pemeriksaan fisik dan laboratorium (tekanan darah sistolik, tekanan darah diastolik, MAP, trombosit, proteinuria, gula darah puasa, asam urat, LDH, SGOT, SGPT, ureum dan kreatinin) pada kelompok preeklamsia tanpa komplikasi ( $p<0.05)$ pada saat persalinan dibandingkan saat 6 minggu pasca salin. Serta didapatkan perbedaan hasil pada seluruh variabel pemeriksaan fisik dan laboratorium pada kelompok preeklamsia dengan komplikasi ( $\mathrm{p}<0.05$ ) pada saat persalinan dibandingkan saat 6 minggu pasca salin. Didapatkan normalisasi nilai pengukuran pada semua variabel pemeriksaan fisik dan pemeriksaan laboratorium baik pada kelompok preeklamsia tanpa komplikasi ataupun dengan komplikasi.

Kesimpulan: Pada saat pengukuran 6 minggu pasca salin, didapatkan normalisasi dari parameterparameter yang dinilai, baik pada kelompok preeklamsia tanpa komplikasi ataupun kelompok preeklamsia dengan komplikasi.

Kata kunci: Enam minggu pasca salin, persalinan, preeklamsia dengan komplikasi, preeklampsia tanpa komplikasi.

\section{PERAN EKSTRAK ANGKAK BERAS MERAH DALAM MEMPERBAIKI KERUSKAN SEL ENDOTEL SECARA IN VITRO MELALUI PERUBAHAN KADAR HMOX-1, SFLT-1, PLGF PADA LINI SEL HUVEC}

Ridwan A Putra ${ }^{1}$, Jusuf S Effendi ${ }^{1}$, Wiryawan Permadi ${ }^{1}$, Ria Bandiara ${ }^{1}$, Prima N Fauziah ${ }^{2}$

\section{${ }^{1}$ Medical Faculty Padjajaran University, Dr. Hasan Sadikin General Hospital, \\ ${ }^{2}$ School of Health Science Jendral Achmad Yani, Bandung-Indonesia}

Latar belakang: Iskemik plasenta dan ketidakseimbangan angiogenik diduga merupakan faktor penyebab utama dari preeklamsi. Ketidakseimbangan angiogenik terjadi akibat meningkatnya kadar sFlt-1 dan penurunan PlGF. Pemulihan keseimbangan angiogenik berpotensi dapat menyembuhkan preeklamsi. Diketahui derivat statin diyakini dapat mengurangi ketidakseimbangan angiogenik sehingga berperan dalam proses pemulihan preeklamsi dengan cara menginduksi ekspresi Hmox-1 sehingga menghambat pelepasan sFlt-1. Lovastatin yang secara alami dapat diperoleh dari pangan hasil fermentasi pada angkak beras merah diyakini memiliki potensi efek menjaga keseimbangan angiogenik dengan jalur tersebut. Penggunaan angkak beras merah sebagai pangan tradisional Indonesia nantinya diharapkan dapat digunakan sebagai alternatif penatalaksanaan peeklampsia.

Tujuan: Untuk mengetahui efek angkak beras merah dalam proses angiogenesis preeklamsi melalui perubahan kadar Hmox-1, sFlt-1 dan PlGF.

Metode: Penelitian ini dilakukan secara eksperimental post test only control group design yakni dengan cara menganalisis kadar Hmox-1, sFlt-1 dan PlGF secara in vitro pada lini sel HUVEC ATCC CRL 1730 yang diinduksi serum normal dan preeklamsi lalu diberikan perlakuan ekstrak angkak beras merah dengan masa inkubasi 72 jam.

Hasil: Hasil penelitian ini menunjukkan nilai LC50 adalah $500 \mu \mathrm{g} / \mathrm{ml}$ dan serial konsentrasi yang digunakan mulai dari 0,977-250 $\mu \mathrm{g} / \mathrm{ml}$. Efek ekstrak angkak beras merah terhadap peningkatan kadar Hmox1 dan PlGF secara bermakna terlihat pada konsentrasi 31,25 dan 1,953 $\mu \mathrm{g} / \mathrm{ml}$ serta penurunan kadar sFlt-1 pada konsentrasi $31,25 \mu \mathrm{g} / \mathrm{ml}(\mathrm{p} \leq 0,005)$. Penelitian ini mendapatkan bahwa angkak beras merah dapat meningkatkan kadar Hmox-1 dan PlGF dan menurunkan kadar sFlt-1 pada sel HUVEC serta perubahannya yang dipengaruhi oleh konsentrasi dan jenis serum.

Kesimpulan: Temuan ini menunjukkan bahwa angkak beras merah dapat berperan sebagai agen yang 
menjaga keseimbangan angiogenesis sehingga dapat mencegah dan memperbaiki kerusakan sel endotel yang pada akhirnya dapat digunakan sebagai alternatif untuk penetalaksanaan preeklamsi di masa yang akan datang.

Kata kunci: Angkak beras merah, preeklamsi, Hmox-1, sFlt-1, PlGF.

\section{TATALAKSANA GIGANTOMASTIA GESTASIONAL - SEBUAH LAPORAN KASUS LANGKA}

Leonita Triwachyuni A S, Bram Pradipta

Departemen Obstetri dan Ginekologi, Fakultas

Kedokteran Universitas Indonesia, Rumah Sakit Umum Daerah Koja Jakarta

Latar belakang: Gigantomastia gestasional adalah suatu kelainan pembesaran salah satu atau kedua payudara selama masa kehamilan yang jarang ditemukan (angka kejadian 1:28.000 hingga 1: 100.000 kehamilan). Gigantomastia umumnya berkembang dengan cepat selama kehamilan dan kembali pada kondisi normal setelah kehamilan. Terdapat kasus-kasus di mana penanganan lebih lanjut dibutuhkan, baik berupa penanganan medis maupun bedah. Dengan patogenesis yang masih belum sepenuhnya diketahui, berbagai teori dikembangkan untuk menjelaskan kejadian gigantomastia, seperti hipersensitivitas organ dan ketidakseimbangan hormon. Gejala yang terjadi dapat berkembang menjadi komplikasi yang membahayakan jiwa pasien.

Tujuan: Mendeskripsikan tatalaksana sebuah kasus langka yaitu kehamilan dengan gigantomastia.

Laporan Kasus: Ny S, 36 tahun, G6P3A2 hamil 31-32 minggu dengan gigantomastia. Pembesaran payudara diketahui dari peningkatan ukuran bra (awalnya 36A, pada kehamilan ini 46). Pada hari perawatan ke-3 pasien mengalami perburukan yang diawali dengan sesak napas berat, demam dan takikardia, kemudian diikuti penurunan kesadaran. Pasien meninggal dunia pada perawatan hari ke-4.

Pembahasan: Gigantomastia gestasional adalah kelainan pembesaran payudara secara masif dan difus, mencapai 10-20 kali ukuran payudara atau $>1.5 \mathrm{~kg}$ massa payudara awal. Komplikasi yang ditimbulkan berupa infeksi, nekrosis, kelainan saraf, hingga sepsis yang berujung kepada kematian. Mengingat penyakit autoimun merupakan faktor risiko, deteksi dini gigantomastia perlu dilakukan agar penanganan yang diberikan holistik dan komprehensif. Penatalaksanaan yang mencakup pembedahan dan non-pembedahan bergantung pada kondisi masing-masing pasien.
Keterlibatan tim multidisiplin diperlukan untuk menghasilkan keluaran yang lebih baik.

Kesimpulan: Perlu dilakukan deteksi dini pada gigantomastia gestasional dan penanganan multidisiplin untuk mendapatkan keluaran yang lebih baik.

Kata kunci: Gigantomastia, komplikasi, kehamilan.

\section{INFEKSI VIRUS VARICELLA ZOSTER DALAM KEHAMILAN}

Aditiya Maulana

Departemen Kebidanan dan Kandungan, Fakultas

Kedokteran Universitas YARSI / RSPAD Gatot Soebroto, Jakarta

Latar belakang: Insiden Varicella zoster virus (VZV) hanya sekitar $2 \%$ terjadi pada orang dewasa. Lesi pada varicella mempunyai gambaran yang khas yaitu terdapatnya semua stadium lesi secara bersamaan pada satu saat. Ibu hamil yang terkena infeksi VZV primer dapat menularkan infeksi kepada janinnya secara transplasental. Penelitian pada orang dewasa sehat dengan infeksi Varicella primer yang diberi terapi awal acyclovir oral menunjukkan perbaikan yang bermakna.

Tujuan: Mengenal infeksi dan tatalaksana Varicella zoster pada kehamilan.

Laporan Kasus: Seorang wanita usia 35 tahun G2P1A0 hamil 20 minggu datang dengan keluhan gatal dan timbul lenting - lenting seluruh tubuh sejak satu hari yang lalu. Lenting - lenting berisi cairan dimulai dari wajah dan semakin banyak menyebar ke seluruh tubuh. Memiliki riwayat kontak dengan penderita cacar air. Sebelumnya pasien mengaku tidak memiliki riwayat cacar air. Dari pemeriksaan fisik status dermatologis regio generalisata, terdapat vesikel - vesikel berukuran numuler - lentikuler yang tersebar di atas kulit eritematus dan terdapat krusta di sebagian tempat. Lain - lain dalam batas normal. Pemeriksaan penunjang seperti Laboratorium, CTG dan USG Transabdominal dalam batas normal. Berdasarkan anamnesis dan pemeriksaan fisik, pasien didiagnosa G2P1A0, hamil 20 minggu dengan infeksi varicella zoster. Setelah intervensi dengan pemberian acyclovir oral 5 x 800mg selama 5 hari di ruang isolasi dan pemberian suportif lainnya keadaan pasien membaik.

Kesimpulan: Infeksi Varicella zoster jarang pada ibu hamil. Bagi ibu yang sedang hamil, Varicella merupakan masalah yang penting karena pada orang dewasa penyakitnya lebih berat dari pada anak-anak. Acyclovir telah digunakan secara aman pada ribuan wanita selama kehamilan. 
Kata kunci: Varicella zoster, kehamilan, acyclovir.

\section{LAPORAN KASUS: DIAGNOSIS DAN TATALAKSANA TWIN-TO-TWIN TRANFUSION SYNDROME TAHAP V DI DAERAH TERPENCIL}

\author{
Bennovry J, Daud S
}

\section{RS H. Lalu Manambai Abdulkadir, Sumbawa Besar, Nusa Tenggara Barat, Indonesia}

Twin-to-Twin Transfusion Syndrome (TTTS) merupakan salah satu kelainan perkembangan janin multifetal monokorionik. Kasus TTTS termasuk kasus yang jarang ditemukan namun memiliki tingkat mortalitas dan morbiditas yang tinggi terhadap janin. TTTS didiagnosis melalui ultrasonografi dengan dua kriteria yakni, kehamilan ganda monokorionikdiamnionik dan adanya gambaran polihidramnion pada janin resipien dan oligohidramnion pada janin pendonor. Kasus ini cukup sulit didiagnosis dan dibedakan dengan kasus lain seperti kehamilan ganda tanpa TTTS dan TRAP. Pada minggu ke-27-28, janin-2 mengalami IUFD yang meningkatkan kecurigaan terhadap TTTS. Tatalaksana yang menjadi standar adalah amnioreduksi dan ablasi laser. Namun, pada daerah terpencil, tatalaksana tersebut sulit dilakukan karena terbatasnya fasilitas, faktor sosioekonomi, dan demografi. Ibu dan janin diobservasi melalui kunjungan antenatal secara rutin setiap dua minggu. Pada setiap kunjungan antenatal, dilakukan pemeriksaan menyeluruh pada ibu dan janin serta dilakukan pemeriksaan ultrasonografi. Observasi dilakukan hingga 24 jam setelah persalinan. Pasien dilakukan seksio sesarea (SC) terjadwal dengan indikasi janin-1 mengalami IUGR dan janin-2 IUFD. Dengan berbagai pertimbangan, kehamilan dipertahankan dengan observasi ketat pada ibu dan janin. Kasus TTTS tahap V di daerah terpencil dapat dilakukan secara konservatif, yakni dengan pemantauan ketat melalui kunjungan antenatal setiap dua minggu, meskipun dengan terbatasnya alat diagnosis dan tatalaksana.

Kata kunci: daerah terpencil, kematian janin tunggal, tatalaksana konservatif, TTTS.

\section{PEMBERIAN BROMOKRIPTIN PADA KASUS KARDIOMIOPATI PERIPARTUM: LAPORAN KASUS DAN TINJAUAN PUSTAKA}

I Wayan Sumardhi ${ }^{1}$, I Made Ariyana ${ }^{1,2}$, A. A Istri Murwitha Prasanti ${ }^{3}$, I Gede Widhyasa ${ }^{4}$, I Made Adi Kusuma ${ }^{5}$, Ketut Yoga Mira Pratiwi ${ }^{6}$, Erliana Fani ${ }^{6}$
1Staff SMF Obstetrik dan Ginekologi FK UNUD/RSUP

Badung Mangusada, Bali

2PPDS-2 Divisi Fetomaternal Departemen/KSM

Obstetrik dan Ginekologi FK UGM

3Staff SMF Ilmu Spesialis Jantung dan Pembuluh

Darah RSUP Badung Mangusada, Bali

4Staff SMF Ilmu Penyakit Dalam RSUP Badung

Mangusada, Bali

5Staff SMF Ilmu Anestesi dan Reanimasi RSUP Badung

Mangusada, Bali

6PPDS-1 Departemen/KSM Obstetrik dan Ginekologi FK UNUD/RSUP Sanglah, Denpasar, Bali

Latar belakang: Peripartum cardiomyopathy (PPCM) merupakan salah satu penyebab gagal jantung dengan angka morbiditas dan mortalitas yang tinggi. Tingginya kadar prolaktin dan produksi fragmen proteolitik prolaktin (16 $\mathrm{kDa} \mathrm{N}$-terminal fragment) berperan penting pada patofisiologi PPCM. Prolaktin dan fragmen prolaktin memicu kerusakan endotel dan disfungsi kardiomiosit melalui inflamasi dan stress oksidatif. Bromokriptin menghambat sekresi prolaktin kelenjar pituitari dan secara klinis dapat memperbaiki fungsi ventrikel kiri.

Laporan Kasus: Seorang wanita hamil, 29 tahun, datang ke IGD kamar bersalin dengan keluhan sesak nafas sejak 3 hari. Riwayat hipertensi sejak usia kehamilan 24 minggu. Tidak ada riwayat penyakit jantung atau penyakit medis lain sebelumnya. Primary survey ditemukan kesadaran compos mentis, jalan nafas paten, pernafasan spontan, RR $28 \mathrm{x} /$ menit, saturasi oksigen $88 \%$, TD $187 / 120 \mathrm{mmHg}$, nadi $150 \mathrm{x} /$ menit. Ditemukan ronki kedua lapang paru dan pitting edema pada kedua kaki. Pemeriksaan obstetri ditemukan janin tunggal/hidup, presentasi bokong, TBJ 2800 gram, DJJ 176, NST tidak reaktif. Pemeriksaan laboratorium ditemukan proteinuria +4 dan asidosis metabolik. Ekokardiografi menunjukkan EF 26\%, LA dilatation, global hypokinetic, MR Mild, TR Mild. Diagnosis awal Fetal Distress, Impending Gagal Nafas, Suspek PPCM, Edema Paru Akut, Preeklamsia Berat, Presentasi Bokong, G2P1A0 36 minggu. Terapi awal meliputi oksigen, drip nikardipin, furosemid, dan magnesium sulfat. Dilakukan SC emergensi atas indikasi fetal distress, lahir bayi laki-laki, 2400 gram, AS 4-7, kelainan kongenital (-). Konsultasi dengan sejawat Kardiologi ditemukan ADHF profil B ec PPCM, post SVT, AF RVR. Terapi gagal jantung meliputi diuretik, antihipertensi, antiaritmia, dan inotropik. Pasien dirawat di ruang ICU selama 6 hari. Pada periode postpartum, diberikan terapi bromokriptin dengan dosis $2,5 \mathrm{mg} / \mathrm{hari}$ selama 2 minggu dilanjutkan dengan $1,25 \mathrm{mg} /$ hari selama 2 minggu berikutnya. Evaluasi ekokardiografi postpartum menunjukkan perbaikan fungsi ventrikel kiri (LVEF 61,9\%). 
Kesimpulan: Pemberian bromokriptin sebagai tambahan terapi standar gagal jantung pada kasus PPCM dapat memperbaiki luaran klinis pasien.

Kata kunci: PPCM, bromokriptin, luaran klinis, multidisiplin.

\section{SINDROM EISENMENGER DALAM KEHAMILAN APAKAH SELALU BERAKHIR DENGAN KEMATIAN?}

Febia Erfiandi, Ita Fatati, Imelda Rosmaida Siagian, Muhammad Alamsyah Aziz

\section{Departmen Obstetri dan Ginekologi, Fakultas Kedokteran Universitas Padjadjaran/RSUP. Dr. Hasan Sadikin, Jalan Pasteur No. 38, Bandung 40161, Indonesia}

Latar Belakang: Sindrom Eisenmenger dalam kehamilan adalah kasus yang jarang, namun angka kematian pada bayi dan ibu sangatlah tinggi, terutama saat kondisi peripartum $(>50 \%)$. Kondisi Sindrom Eisenmenger didefiniskan sebagai kondisi hipertensi pulmonal secara sistemik yang disebabkan adanya resistensi yang tinggi di pembuluh darah pulmonal dengan aliran darah dari jantung kanan ke jantung kiri. Perubahan fisiologi dalam kehamilan dapat menyebabkan aliran dari kanan ke kiri yang melalui defek kongenital pada jantung memburuk, menyebabkan hipoksia berat, dan prognosis yang buruk bagi ibu dan bayi.

Laporan Kasus: Dalam laporan kasus ini, dibahas 2 kasus sindrom Eisenmenger pada kehamilan. Kasus pertama berakhir dengan kematian ibu, sedangkan kasus kedua ibu keluar rumah sakit dengan kondisi tanpa keluhan. Kami memberikan pengobatan standar untuk kedua kasus berupa seperti sildenafil sitrat, antikoagulan, dan diuretik. Namun diberikan anti hipertensi dan magnesium pada kasus pertama karena preeklamsia berat. Namun perbedaanya, obatnya lebih lama pada kasus kedua. Pada hari kedua kami merawat pasien di unit perawatan intensif selama 5 hari, dipindahkan ke unit perantara selama sekitar 3 hari, dan kemudian kami merawatnya di ruang rawat biasa selama seminggu. Kami memberikan analgesik intravena selama sekitar 5 hari di unit perawatan intensif melalui epidural dan diberhentikan pada hari ke-14. Beberapa referensi menyebutkan pemberian anastesi lokal dan narkotik dapat menghambat resistensi vaskular perifer. Dan dari Serial laporan kasus ini dapat disimpulkan kehamilan tidak disarankan bagi wanita dengan sindrom Eisenmenger karena luaran yang buruk untuk ibu dan bayi, namun wanita yang memilih hamil harus dirawat secara komprehensif oleh tim dengan multi disiplin ilmu di pusat kesehatan tersier. Pilihan metode persalinan sebaiknya dengan Seksio sesarea dengan anestesi epidural dan narkotik sebagai analgetik dalam dosis yang tepat. Pemantauan ketat volume darah selama periode postpartum merupakan hal yang penting.

Kata kunci: Sindrom eisenmenger, kehamilan.

\section{HUBUNGAN KADAR PROGESTERON SALIVA DENGAN KEJADIAN ANCAMAN PERSALINAN PREMATUR}

Dewi Maharsita Sri Prajanta Putri, Hadi Susiarno, Budi Handono

Latar Belakang: Persalinan preterm adalah persalinan yang terjadi pada usia kehamilan 20 minggu atau lebih sampai dengan kurang dari 37 minggu. Persalinan preterm menyebab-kan peningkatan mortalitas dan morbiditas neonatal. Progesteron merupakan hormon steroid yang bertanggungjawab dalam mempertahankan status quiscence miometrium. Onset persalinan baik aterm maupun preterm diperkirakan disebabkan oleh penurunan aktivitas fungsional progesteron didalam uterus sehingga terjadi inisiasi proses persalinan dan modulasi kontraktilitas serta eksibilitas miometrium.

Tujuan: Penelitian ini dilakukan untuk mengetahui apakah kadar progesteron saliva berkorelasi dengan kejadian persalinan preterm. Jika kadar progesteron berkorelasi dengan persalinan preterm kemudian dicari nilai cut off progesteron untuk memprediksi risiko persalinan preterm.

Metode: Rancangan penelitian adalah analitik observasional dengan studi Cross Sectional yaitu membandingkan kadar progesteron pada kelompok ancaman persalinan preterm pada wanita hamil usia gestasi 28-36 minggu. Kelompok ancaman persalinan preterm yang masuk dalam subjek penelitian harus memenuhi kriteria inklusi dengan besaran sampel $n=68$. Periode penelitian berlangsung dari bulan JanuariMaret 2019 dengan mengambil sampel yang berobat di RSUP Dr. Hasan Sadikin Bandung. Sampel saliva diambil dan dilakukan pengamatan terhadap subjek selama perawatan konservatif di rumah sakit. Kelompok yang lahir preterm dalam perawatan dimasukkan dalam kelompok dengan preterm dan kelompok yang berhasil dalam perawatan konservatif dimasukkan dalam kelompok tanpa preterm. Pada kedua kelompok dilakukan pemeriksaan kadar progesteron dengan metode ELISA(enzyme linked immunosorbent assay).

Hasil: Hasil penelitian menunjukkan kadar progesteron rata-rata pada kelompok dengan persalinan preterm sebesar $411,75 \mathrm{pg} / \mathrm{ml}$ sedang kelompok tanpa persalinan preterm sebesar 1082,54 pg/ml. Perbedaan 
kadar rata-rata progesteron pada kedua kelompok tersebut bermakna dengan nilai $\mathrm{p}$

Kata kunci: Progesteron saliva, persalinan preterm, ancaman persalinan pre.

\section{ANALISIS KOMPARASI DIAGNOSIS GAWAT JANIN BERDASARAKAN GAMBARAN KTG KATEGORI 3 (NICHHD) DENGAN PENILAIAN MAEDA DI RSUP SANGLAH DENPASAR PERIODE 1 JANUARI 2015 - 31 DESEMBER 2016}

Mervinna Giovanni, AAN Jaya Kusuma, I Wayan Artana Putra, AA Putra Wiratnyana, I Wayan

Megadhana

Divisi Fetomaternal SMF/Bagian Obstetri dan Ginekologi RSUP Sanglah/Universitas Udayana, Bali, Indonesia

Latar Belakang: Diagnosis Gawat Janin selama persalinan sangatlah penting, Kardiotokografi (KTG) merupakan alat pantau yang paling lazim digunakan, namun metode ini memiliki spesitifitas yang rendah sehingga pada pengunaannya mengakibatkan meningkatnya angka persalinan secara operatif, tanpa menurunkan mortalitas perinatal.

Metode: Pada penelitian deskriptif ini kami akan mecari perbandingan KTG Kategori 3 dengan penilaian MAEDA pada keluaran pada bayi, yang dilakukan di RSUP Sanglah pada periode 1 Januari 2015-31 Desember 2016.

Hasil: Sampel penelitian sebanyak 11 gambaran KTG Kategori 3 yang dilakukan SC yang didapatkan dengan keluaran bayi, $81,8 \%$ memiliki nilai APGAR $<7$, dan $90 \%$ mengalami asiodosis dilihat dari $\mathrm{pH}$ analisis gas darah umbilikal. Dari KTG Kategori 3 yang dilakukan penilaian MAEDA, 54,5\% didapatkan dengan nilai $>15$. Pada nilai MAEDA $>15$ semuanya didapatkan dengan APGAR $<7$, dan $\mathrm{pH}$ analisis gas darah umbilikal $<7,2$. Pada penelitian ini didapatkan sensitifitas dari Penilaian MAEDA pada gawat janin dengan gambaran KTG Kategori 3 adalah 88,9\%, dan spesitifitas sebesar $50 \%$.

Kata kunci: Kardiotokografi, kategori 3, penilaian maeda, gawat janin.

\section{DETERMINAN LUARAN BAYI BERAT LAHIR RENDAH PADA WANITA DENGAN KETUBAN PECAH DINI}

Sarah Chairani Zakirah ${ }^{1,3,4 *}$, Putri Chairani Eyanoer ${ }^{5}$, Dina Fadilla ${ }^{4}$, Budi Wiweko ${ }^{1,2,3}$
${ }^{l}$ Divisi Fertilitas Endokrinologi dan Reproduksi, Departemen Obstetri and Ginekologi, Fakultas Kedokteran, Universitas Indonesia, Jakarta, 10430, Indonesia, ${ }^{2}$ Klinik Yasmin IVF, RSUP Dr. Cipto Mangunkusumo, Jakarta, 10430, Indonesia. ${ }^{3}$ Klaster Human Reproductive, Infertility and Family Planning Research Center, Indonesia Medical Education and Research Institute (IMERI), Fakultas Kedokteran, Universitas Indonesia, Jakarta, 10430, Indonesia, ${ }^{4}$ Fakultas Kedokteran, Universitas Sumatera Utara, Medan, Indonesia, ${ }^{5}$ Departemen Kedokteran Komunitas, Fakultas Kedokteran, Universitas Sumatera Utara, Medan, Indonesia

*Korespondensi: sarahchairani@gmail.com

Tujuan: Berbagai faktor dikatakan sebagai risiko terkait BBLR. Penelitian ini bertujuan untuk mengevaluasi faktor risiko antenatal yang berperan terhadap luaran BBLR pada wanita usia reproduktif yang mengalami KPD.

Metode: Penelitian ini merupakan penelitian observasional analitik dengan desain penelitian crosssectional, dimana mengkaji hubungan antara beberapa faktor risiko terkait kejadian BBLR pada wanita dengan PROM. Sampel diambil dengan menggunakan cara consecutive sampling dari tanggal 22 April 2018 hingga 15 Mei 2018 di Instalasi Rekam Medis Rumah Sakit Umum Kertha Usada, Buleleng, Bali. Data yang digunakan pada penelitian ini adalah data nonparametrik yaitu berupa data nominal dan ordinal dengan analisis data menggunakan uji Chi-Square atau Kruskal-Wallis jika data tidak memenuhi syarat.

Hasil: Pada penelitian ini, terdapat jumlah responden PROM dan PPROM sebanyak 260 orang, dimana 48 orang tidak memenuhi kriteria, sehingga terdapat 212 orang yang memenuhi kriteria. Dari 212 orang diklasifikasikan menjadi 3 kelompok, yakni BBLN, BBLB, BBLR. Responden BBLN sebanyak 200 bayi $(94.3 \%)$, BBLB sebanyak 6 bayi $(2.8 \%)$, BBLR sebanyak 6 bayi (2.8\%). Data menunjukkan bahwa terdapat hubungan yang signifikan antara variable usia kehamilan $(\mathrm{p}<0.01)$ dan NLR $(\mathrm{p}=0.048)$ dengan bayi berat lahir rendah (BBLR).

Kesimpulan: Kecilnya usia kehamilan dan tingginya NLR dapat digunakan sebagai prediktor faktor risiko luaran BBLR. Penelitian dengan sampel yang lebih besar dan pemerataan jumlah sampel dengan BBLB dan BBLR dibutuhkan mengingat penelitian ini responden terbanyak berasal dari kelompok BBLN.

Kata kunci: BBLR, KPD, faktor risiko. 


\section{OPTIMASI PEMAPARAN SINAR MATAHARI UNTUK MENCEGAH DEFISIENSI VITAMIN D PADA IBU HAMIL: LAPORAN DARI KOHOR IBU HAMIL DI JAWA BARAT}

Raden Tina Dewi Judistiani ${ }^{1 *}$ Sefita Aryuti Nirmala ${ }^{1,2}$, Meilia Rahmawati ${ }^{3}$, Reni Ghrahani ${ }^{4}$, Yessika Adelwin Natalia $^{1}$, Adhi Kristianto Sugianli ${ }^{5}$, Agnes Rengga Indriati $^{5}$, Oki Suwarsa ${ }^{6}$, Budi Setiabudiawan ${ }^{4}$

${ }^{I}$ Departemen Ilmu Kesehatan Masyarakat, Fakultas Kedokteran Universitas Padjadjaran,

${ }^{2}$ Program Studi D.IV Kebidanan Fakultas Kedokteran Universitas Padjadjaran, ${ }^{3}$ Program Studi D.III Kebidanan Universitas Islam Sultan Agung Semarang ${ }^{4}$ Departemen Ilmu Kesehatan Anak Fakultas Kedokteran Universitas Padjadjaran,

${ }^{5}$ Departemen Patologi Klinik Fakultas Kedokteran Universitas Padjadjaran, ${ }^{6}$ Departemen Ilmu Kesehatan Kulit dan Kelamin Fakultas Kedokteran Universitas Padjadjaran,

*Koresponden: tina.d.judistiani@unpad.ac.id

Latar belakang: Peran vitamin D dalam trimester pertama penting untuk fetal programming. Konversi vitamin $\mathrm{D}$ di bawah kulit oleh radiasi sinar matahari lebih aman dibandingkan mengkonsumsi suplemen. Diduga waktu dan durasi pemaparan, ketinggian lokasi, derajat pigmentasi, tipe pakaian, luas permukaan area tubuh (LPT) yang terpapar sinar matahari turut berpengaruh.

Tujuan: Mengetahui prevalensi defisiensi vitamin D ibu hamil trimester pertama, perilaku ibu hamil terkait pemaparan terhadap sinar matahari, mengetahui rekomendasi waktu dan durasi pemaparan sinar matahari untuk menghindarkan defisiensi.

Metode: Studi kohor mengikutsertakan $304 \mathrm{ibu}$ hamil trimester 1 dari 4 kota di Jawa Barat. Kadar vitamin D diukur dengan metode ELISA, pencatatan aktivitas ibu hamil selama 3 hari meliputi waktu, durasi dan LPT terpapar sinar matahari. Besaran radiasi sinar matahari diperoleh dari Lembaga Antariksa dan Penerbangan Nasional di Bandung bulan September 2016 sd Maret 2017.

Hasil: Prevalensi defisiensi vitamin D ibu hamil trimester 1 mencapai 80,6\%. Rerata kadar vitamin D sebesar $14.7 \mathrm{ng} / \mathrm{mL}$, median $13.6 \mathrm{ng} / \mathrm{mL}$. Kadar tertinggi vitamin D mencapai 39ng/mL, namun $42 \mathrm{ibu}$ hamil $(13,8 \%)$ kadarnya sangat rendah $(<8,1 \mathrm{~g} / \mathrm{mL})$. Nilai median LPT terpapar sinar matahari $0,48 \mathrm{~m} 2$ atau $18.59 \%$. Terdapat korelasi antara kadar vitamin D dalam serum dengan LPT terpapar sinar matahari dalam $\mathrm{m} 2(\mathrm{r}=0.36, \mathrm{p}<0.002)$ atau prosentasenya $(\mathrm{r}=0.39$, $\mathrm{p}<0.001)$ dan intensitas radiasi $(\mathrm{r}=0.15, \mathrm{p}=0.029)$. Radiasi ultraviolet optimal diperoleh pukul 10.00-13.00, namun durasi pemaparan responden sangat rendah dan terputus-putus. Untuk warna kulit tipe III-IV tercatat kebutuhan waktu pemaparan kontinyu selama 37,5 menit bila berpakaian kasual dan 64,5 menit bila berhijab.

Kesimpulan: Prevalensi defisiensi vitamin D pada ibu hamil masih sangat tinggi. Optimalisasi pemaparan sinar matahari perlu dilakukan antara pukul 10.0013.00, secara kontinyu selama 37,5 menit untuk ibu hamil berpakaian kasual (18,59 \% LPT) dan 64,5 menit bila hanya menampakkan wajah dan tangan.

Kata kunci: Ibu hamil, pemaparan sinar matahari, vitamin D.

\section{PERBANDINGAN EFEKTIFITAS PEMBERIAN TOKOLITIK NIFEDIPIN DAN ISOKSUPRIN TERHADAP KONTRAKSI UTERUS PADA KEJADIAN ANCAMAN PERSALINAN PRETERM DI RUMAH SAKIT HASAN SADIKIN BANDUNG}

Herry Aktyar Matondang

Fakultas Kedokteran Universitas Padjadjaran, RSUP Dr. Hasan Sadikin Bandung

Latar belakang: Persalinan preterm masih menjadi masalah utama di bidang obstetri karena mengakibatkan angka mortalitas dan morbiditas neonatal yang tinggi. Salah satu upaya pencegahan persalinan preterm yaitu dengan pemberian tokolitik untuk memberikan kesempatan pemberian kortikosteroid sebagai obat pematangan paru. Nifedipin dan isoksuprin merupakan tokolitik yang keduanya efektif tetapi protokol pemberiannya diberbagai senter masih bervariasi. Penelitian ini bertujuan untuk mengetahui perbedaan perubahan frekuensi dan kekuatan uterus antara pemberian nifedipin dengan isoksuprin.

Metode: Penelitian ini merupakan penelitian randomized controlled trial (RCT) dengan metode randomisasi double blind. Subjek penelitian adalah wanita hamil yang memenuhi kriteria penelitian $(n=16)$. Perlakuan diberikan selama 48 jam. Parameter yang diukur yaitu frekuensi dan kekuatan kontraksi sebelum dan sesudah pemberian terapi tokolitik nifedipin dan isoksuprin. Penelitian dilakukan di RSUP Dr. Hasan Sadikin pada bulan Januari sampai dengan Maret 2019.

Hasil: Hasil penelitian menunjukkan terdapat penurunan frekuensi dan kekuatan kontraksi uterus lebih besar setelah pemberian tokolitik isoksuprin selama 48 jam dibandingkan dengan tokolitik nifedipin dan signifikan secara statistik dengan nilai p 0,0001 $(\mathrm{p}<0,05)$ menggunakan uji Mann Whitney.

Kesimpulan: Pemberian tokolotik isoksuprin lebih efektif untuk menurunkan frekuensi dan kontraksi 
uterus dibandingkan dengan nifedipin terhadap ancaman persalinan preterm.

Kata kunci: Nifedipin, isoksuprin, frekuensi dan kekuatan kontraksi, ancaman persalinan preterm.

\section{TEMUAN PLASENTA AKRETA INSIDENTAL DAN TATALAKSANA DI DAERAH TERPENCIL: SEBUAH LAPORAN KASUS}

Putri $\mathrm{A}^{1}$, Wahono $\mathrm{WT}^{1}$, Saroyo $\mathrm{YB}^{2}$, Nugroho $\mathrm{AJ}^{1}$, Marjono $\mathrm{B}^{3}$

${ }^{I}$ RSUD Puruk Cahu, Kalimantan Tengah

${ }^{2}$ Departemen Obstetri dan Ginekologi, Universitas

Indonesia, Jakarta

${ }^{3}$ RS Medistra, Jakarta

Latar belakang: Plasenta akreta merupakan suatu kondisi dimana plasenta melekat pada miometrium secara patologis dan dapat menyebabkan komplikasi berbahaya termasuk perdarahan postpartum yang hebat. Salah satu hipotesis menyatakan bahwa penyebabnya adalah defek dari lapisan antara endometriummiometrium sehingga desidualisasi pada area bekas luka pada uterus menjadi abnormal. Evaluasi melalui ultrasonografi merupakan hal yang penting. Pada kasus tidak tersedianya evaluasi ultrasonografi, faktor risiko klinis dapat membantu prediksi plasenta akreta, seperti riwayat persalinan sesar sebelumnya. Insiden plasenta akreta pada wanita tanpa riwayat persalinan sesar sebelumnya sebesar $0.24 \%$ dan meningkat mencapai $3 \%$ bila disertai dengan plasenta previa.

Tujuan: Deskripsi diagnosis dan tatalaksana temuan insidental kasus plasenta akreta dalam keterbatasan di daerah terpencil.

Kasus: Wanita 39 tahun, P5, dengan syok hipovolemik karena perdarahan postpartum et causa retensio plasenta pada persalinan spontan pervaginam yang dibantu dukun kampung. Tidak didapatkan riwayat sesar atau kuretase sebelumnya dan tidak pernah melakukan antenatal care. Resusitasi cairan dan transfusi darah diberikan bersamaan dengan manual plasenta, dimana plasenta sulit untuk dipisahkan dari dinding uterus dan tercabik saat dikeluarkan. Diputuskan untuk dilakukan laparotomi dan dilanjutkan dengan histerektomi subtotal untuk menghentikan perdarahan. Hasil histopatologi didapatkan adanya sel trophoblast hingga lapisan myometrium, sesuai dengan plasenta akreta. Kasus ini merupakan kasus plasenta akreta tanda riwayat operasi ataupun kuretase sebelumnya, dengan temuan insidental pada kasus retensio plasenta.

Kesimpulan: Pada kasus ini tidak adanya riwayat sesar dan kuretase sebelumnya ataupun plasenta previa tidak menyingkirkan kemungkinan terjadinya plasenta akreta. Diagnosis dan tatalaksana yang tepat pada fasilitas terbatas dibutuhksan untuk menghentikan perdarahan dan menyelamatkan ibu.

Kata kunci: Plasenta akreta, dukun kampung, perdarahan postpartum, retensio plasenta.

\section{PERBANDINGAN EFEKTIFITAS PEMASANGAN ALAT KONTRASEPSI DALAM RAHIM (AKDR) PASCASALIN ANTARA TEKNIK MANUAL DAN MENGGUNAKAN ALAT BANTU}

Virdy Kurniawan, John Rambulangi, Masita Fujiko

Departemen Obstetri dan Ginekologi Fakultas

Kedokteran, Universitas Hasanuddin

Latar belakang: Angka Kematian Ibu (AKI) pada tahun 2007 adalah 228 per 100.000 pada tahun 2012 menunjukkan peningkatan AKI menjadi 359 per 100.000 kelahiran hidup. Program Keluarga Berencana (KB) adalah upaya preventif untuk mencegah morbiditas dan mortalitas ibu. AKDR (Alat Kontrasepsi Dalam Rahim) merupakan salah satu jenis alat kontrasepsi non hormonal yang termasuk metode kontrasepsi jangka panjang dimana dapat dipakai lebih dari 5 tahun. Sampai saat ini belum ada metode yang efektif untuk mengurangi efek samping pasca pemasangan.

Tujuan: Penelitian ini bertujuan untuk Menilai efektifitas pemasangan AKDR pascasalin dengan teknik manual dan menggunakan alat bantu

Metode: Penelitian ini merupakan studi analitik observasional dengan desain Penelitian ini adalah cohort prospektif yang pengambilan sampelnya secara random (randomized clinical trial, atau randomized controlled trial). Pada penelitian ini terdapat 180 orang partisipan yang terdiri dari 90 orang pasien yang memasang AKDR dengan alat bantu (kelly's forcep) dan 90 orang pasien memasang AKDR dengan metode manual yang menjalani persalinan di RSUD Labuang Baji. RS Pelamonia, RSKDIA Sitti Fatimah, serta RSIA Sitti Khadijah I di Kota Makassar.

Hasil: Hasil penelitian menunjukkan bahwa penggunaan alat bantu berupa Kelly's Forcep mengurangi secara signifikan efek pasca pemasangan AKDR berupa nyeri dibandingkan dengan metode manual $(\mathrm{p}<0.001)$. Namun tidak terdapat perbedaan bermakna pada efek lainnya berupa perdarahan, ekspulsi, perforasi, serta tingkat drop out. ( $p>0.05)$

Kesimpulan: Berdasarkan hasil penelitian, dapat disimpulkan bahwa penggunaan kelly's forcep akan mengurangi efek nyeri pasca pemasangan AKDR dibandingkan metode manual. 
Kata kunci: AKDR, efek pasca pemasangan, Kelly's Forcep.

\section{DIAGNOSIS DAN TATALAKSANA SELECTIVE INTRAUTERINE GROWTH RESTRICTION (s- IUGR) DI RSUD PURUK CAHU: LAPORAN KASUS}

\author{
Chatrine Sutandi ${ }^{1}$, William Timotius Wahono ${ }^{2}$ \\ ${ }^{1}$ Dokter PTT RSUD Puruk Cahu \\ ${ }^{2}$ Spesialis Obstetri dan Ginekologi RSUD Puruk Cahu \\ Rumah Sakit Umum Daerah Puruk Cahu, Kalimantan \\ Tengah
}

Latar belakang: S-IUGR pada kehamilan Monochorionic Diamniotic (MCDA) didefinisikan sebagai taksiran berat janin di bawah persentil 10th pada janin yang kecil. Prevalensi S-IUGR dilaporkan sebesar $10-15 \%$ pada kehamilan kembar monokorionik.

Tujuan: Laporan kasus ini bertujuan untuk mengetahui cara diagnosis dan tatalaksana mengenai sIUGR.

Laporan kasus: Ny. LSP berumur 37 tahun dengan G2P1 Hamil 35 minggu gemelli monokorionik diamniotik dengan s-IUGR. Pada tanggal 31 Desember 2018, pasien kontrol pertama kali ke poli kandungan untuk Antenatal Care (ANC) pada usia kehamilan 29 minggu 3 hari. Didapatkan kehamilan kembar dengan monokorionik diamniotik. Pada tanggal 15 Februari 2019 pasien kontrol kembali ke poli kandungan. Didapatkan hasil USG: Janin A: Janin presentasi kepala, Indeks Cairan Amnion (ICA) cukup, DJJ (+), TBJ 2500 gram, laki-laki. Janin B: Janin presentasi bokong, ICA $<2 \mathrm{~cm}$, DJJ (+), TBJ 1780 gram, bladder tidak tervisualisasi, laki-laki. Biometri sesuai dengan 35 minggu 3 hari. Taksiran berat janin B di bawah persentil $10 \%$, serta terdapat perbedaan taksiran berat janin keduanya sebesar $28,8 \%$. Terjadi pertumbuhan janin terhambat dan oligohidramnion pada salah satu bayi. Pada kasus ini, tidak dapat dilakukan pemeriksaan UA Doppler karena kemampuan alat USG yang terbatas di RSUD Puruk Cahu. Didapatkan hasil kardiotokografi pada janin B non reaktif, sehingga dilakukan terminasi kehamilan.

Kesimpulan: Pemantauan secara berkala setiap dua minggu dengan ultrasound dianjurkan untuk mengenali secara dini s-IUGR dari kehamilan MCDA. Pemantauan secara berkala dan terminasi yang tepat pada janin dengan gangguan pertumbuhan diterima secara luas.

Kata kunci: S-IUGR, monokorionik diamniotik.

\section{EKSTRAK PHALERIA MACROCARPA MENURUNKAN OTOFAGI MELALUI TNF- $\alpha$ \& MDA PADA KULTUR HUVEC MODEL PREEKLAMPSIA}

Leo Simanjuntak ${ }^{1,2}$, M Fidel Ganis Siregar $^{3}$, Johannes C Mose $^{4}$, Sarma N Lumbanraja ${ }^{3}$

${ }^{1}$ Program Studi Doktor, Fakultas Kedokteran, Universitas Sumatera Utara, Medan

${ }^{2}$ Departmen Obstetri dan Ginekologi, Fakultas Kedokteran, Universitas HKBP, Nommensen, Medan

${ }^{3}$ Departmen Obstetri dan Ginekologi, Fakultas Kedokteran, Universitas Sumatera Utara, Medan ${ }^{4}$ Departmen Obstetri dan Ginekologi, Fakultas Kedokteran, Universitas Padjadjaran, Bandung

Latar belakang: Etiopatogenesis pasti preeklampsia belum diketahui namun disfungsi endotel dan stres oksidatif diyakini memegang peranan penting. TNF- $\alpha$ merupakan salah satu penanda khusus untuk preeklampsia. MDA merupakan produk akhir peroksidasi lipid dan penanda stres oksidatif. Otofagi juga berperan dalam preeklampsia seperti yang diamati pada kegagalan invasi trofoblas dan remodelling arteri spiralis. LC3-II digunakan sebagai penanda pembentukan otofagosom pada proses otofagi. Pada kultur sel trofoblas terbukti bahwa pemberian TNF- $\alpha$ meningkatkan ekspresi LC3-II. Penyebab lain terjadinya otofagi adalah stres oksidatif.

Metode: Penelitian ini menggunakan kultur HUVEC sebagai model in-vitro. Phaleria macrocarpa juga dikenal sebagai Mahkota Dewa secara luas digunakan sebagai anti-inflamasi dan antioksidan.

Tujuan: Penelitian ini bertujuan untuk mengetahui efek ekstrak Phaleria macrocarpa pada inflamasi, stres oksidatif dan otofagi pada sel endotel dengan mengukur kadar TNF- $\alpha$, MDA dan LC3-II pada HUVEC yang diinduksi serum preeklampsia.

Hasil: Ekstrak Phaleria macrocarpa menurunkan kadar TNF- $\alpha$ secara signifikan pada konsentrasi 7.813 $\mu \mathrm{g} / \mathrm{mL}$ dan konsentrasi $62.5 \mu \mathrm{g} / \mathrm{mL}$ menurunkan kadar TNF- $\alpha$ ke kadar normal. MDA mengalami penurunan secara signifikan pada konsentrasi $3.906 \mu \mathrm{g} / \mathrm{mL}$ dan konsentrasi $15.625 \mu \mathrm{g} / \mathrm{mL}$ menurunkan ke kadar normal. Tidak terdapat penurunan signifikan kadar LC3-II dan konsentrasi lebih dari $250 \mu \mathrm{g} / \mathrm{mL}$ dibutuhkan untuk menurunkan ke kadar normal. TNF- $\alpha$ dan MDA masing-masing memiliki korelasi positif yang bermakna dengan LC3-II dengan tingkat korelasi sangat kuat $(\mathrm{r}=0.958$ dan $\mathrm{r}=0.847)$, dimana penurunan kadar TNF- $\alpha$ sebesar 1 pg/mL akan menurunkan kadar LC3-II sebesar $0.413 \mathrm{pg} / \mathrm{mL}$ dan penurunan kadar MDA sebesar $1 \mathrm{pmol} / \mathrm{mL}$ akan menurunkan kadar LC3-II sebesar $0.222 \mathrm{pg} / \mathrm{mL}$. 
Kesimpulan: Penurunan kadar TNF- $\alpha$ memiliki tingkat korelasi yang lebih kuat dibandingkan MDA terhadap kadar LC3-II. Dengan demikian, ekstrak Phaleria macrocarpa dapat digunakan untuk mengatasi disfungi endotel, stres oksidatif dan otofagi pada preeklampsia.

Kata kunci: Preeclampsia, MDA, LC3-II.

\section{TATALAKSANA CAESAREAN SCAR PREGNANCY, HISTEREKTOMI VERSUS KONSERVATIF HISTEROSKOPI: SEBUAH LAPORAN KASUS}

Brilian Utama Putra, Eric Edwin Yuliantara, Nutria Widya Purna Anggraini

Program Pendidikan Dokter Spesialias Obstetri dan Ginekologia, Fakultas Kedokteran RSUD dr. Moewardi Surakarta

Latar belakang: Caesarean scar pregnancy merupakan suatu kehamilan ektopik yang sangat jarang ditemukan. Dalam satu dekade terakhir, kejadian caesarean scar pregnancy semakin meningkat, seiring peningkatan frekuensi persalinan seksio sesaria. Penegakan diagnosis dini mengarah kepada tatalaksana yang tepat dan mengurangi morbiditas dan mortalitas ibu. Hingga saat ini masih belum ada konsensus yang jelas mengenai penatalaksanaan caesarean scar pregnancy.

Tujuan: Melaporkan kasus caesarean scar pregnancy dan pilihan tatalaksana serta hasil luaran yang didapat

Laporan kasus: Melaporkan dua kasus caesarean scar pregnancy. Kasus Pertama Seorang wanita usia 37 tahun, G3P2A0, usia kehamilan 17 minggu dengan diagnosis abortus inkomplet. Riwayat seksio sesaria 2 kali. Sonografi prenatal insersi plasenta di korpus anterior meluas menutupi OUI. Saat Kuretase terjadi perdarahan masif sehingga diputuskan laparotomi eksplorasi emergency. Kasus kedua seorang wanita usia 36 tahun, P2A3, usia kehamilan 9 minggu, pasien rujukan dengan diagnosis perdarahan post kuret abortus inkomplet, riwayat seksio sesaria 2 kali, riwayat kuretase 2 kali. Sonografi prenatal didapatkan janin di $1 / 3$ distal, post kuretase terjadi perdarahan, dilakukan pemasangan balon kateter $50 \mathrm{cc}$, saat evaluasi perdarahan merembes masih terjadi, diputuskan dilakukan prosedur histeroskopi.

Hasil: Kasus pertama durante operasi tampak plasenta insersi di segmen bawah rahim bekas operasi seksio sesaria sebelumnya, melekat erat dengan dinding posterior vesica urinaria sehingga diputuskan histerektomi. Jaringan dikirim ke patologi anatomi.
Kasus kedua, histeroskopi didapatkan sisa produk kehamilan diismus uteri anterior dan dilakukan reseksi menggunakan cutting loop pada area implantasi kehamilan, jaringan dikirim ke patologi anatomi. Hasil pemeriksaan patologi anatomi kedua kasus mendukung gambaran plasenta akreta. Kedua pasien tersebut pulang dalam keadaan baik.

Kesimpulan: caesarean scar pregnancy yang ditemukan pada kehamilan trimester pertama sangat berkaitan dengan insidensi plasenta akreta. Hanya sedikit literatur yang menunjukkan tatalaksana efektif pada kasus caesarean scar pregnancy. Histeroskopi merupakan tatalaksana yang efektif dengan tetap mempertahankan fungsi fertilitas, sedangkan histerektomi menjadi pilihan utama apabila perdarahan massif tidak dapat teratasi.

Kata kunci: Caesarean scar pregnancy, histeroskopi, histerektomi.

\section{STRATEGI PENCEGAHAN KELAHIRAN PRETERM: PENGARUH PEMBERIAN VITAMIN D3 TERHADAP EKSPRESI GEN CORTICOTROPHIN RELEASING HORMONE (CRH), CORTICOTROPHIN RELEASING HORMONE-RECEPTOR 1 (CRH-R1), DAN CONNEXIN-43 (CON-43) PADA PROFIL REGULASI KONTRAKTILITAS SEL LINI PHM1- 41 YANG MENGALAMI STRES OKSIDATIF}

M. Alamsyah Aziz, Sofie R. Krisnadi,1 Budi

Setiabudiawan,2 Budi Handono1

${ }^{1}$ Divisi Fetomaternal, Departemen Obstetri dan Ginekologi, Fakultas Kedokteran, Universitas Padjadjaran/Rumah Sakit dr. Hasan Sadikin Bandung, Indonesia

${ }^{2}$ Departemen Kesehatan Anak, Fakultas Kedokteran Universitas Padjadjaran/Rumah Sakit dr. Hasan Sadikin Bandung, Indonesia

Latar Belakang: Kelahiran preterm merupakan salah satu penyebab kematian neonatal yang masih menjadi permasalahan di seluruh dunia. Data WHO menunjukkan bahwa Indonesia memiliki rasio kelahiran preterm yang masih cukup tinggi sebesar $15,5 \%$ per 100 kelahiran hidup. Data Maternal Perinatal Registrasi Indonesia yang terkumpul dari 11 rumah sakit di Jawa Barat, didapatkan insiden persalinan preterm sebesar $15,82 \%$. Salah satu mekanisme patofisiologis yang menyebabkan terjadinya kelahiran preterm adalah aktivitas sumbu Hipotalamus-Pituitari-Adrenal (HPA). Stres maternal biologis berupa kondisi hipoksia merupakan penyebab terjadinya kelahiran preterm 
melalui jalur aktivasi sumbu HPA. Kondisi stres ini mengakibatkan aktivasi sumbu HPA dan meningkatkan CRH, CRH-R1, dan CON-43 sebagai pemicu terjadinya proses kontraksi. Vitamin D3 sebagai sumber ion $\mathrm{Ca} 2+$ dan antioksidan dibutuhkan untuk mekanisme kontraksi dan relaksasi otot halus miometrium.

Tujuan: Tujuan penelitian ini adalah menganalisis hubungan penambahan vitamin D3 dengan kadar ROS, ekspresi gen $\mathrm{CRH}, \mathrm{CRH}-\mathrm{R} 1$, dan $\mathrm{CON}-43$ pada sel lini PHM1-41 dalam kondisi stres oksidatif.

Metode: Penelitian ini merupakan penelitian eksperimental menggunakan sel lini otot halus miometrium uterus manusia PHM1-41 sebagai model in vitro yang diberi perlakuan stres oksidatif hipoksia dan penambahan vitamin D3 (5, 10, 50 dan 150nM). Dilakukan uji viabilitas untuk toksisitas vitamin D3 terhadap sel yang akan diuji. Sel PHM1-41 yang telah dikultur dalam keadaan hipoksia selama 24 jam diberi penambahan vitamin D3, kemudian diukur kadar ROS menggunakan DCFDA fluoresen. Selain itu, RNA sel diisolasi kemudian dianalisis ekspresi gen yang diperiksa sebagai profil regulasi kontraktilitas.

Hasil: Hasil menunjukkan kadar ROS turun dari $19,49 \pm 1,76 \%$ menjadi $7,16 \pm 0,23 \%$ dan ekspresi seluruh gen lebih rendah pada kelompok yang diberi penambahan vitamin D3 150nM dibandingkan kelompok kontrol hipoksia. Hasil korelasi Pearson menunjukkan hubungan negatif antara penambahan vitamin D3 dengan rendahnya kadar ROS, ekspresi gen $\mathrm{CRH}$, ekspresi gen CRH-R1, dan ekspresi gen CON-43 pada sel lini PHM1-41 dalam kondisi stres oksidatif.

Kesimpulan: Vitamin D3 memiliki potensi dalam mencegah kelahiran preterm.

Kata kunci: CRH, CRH-R1, CON-43, hipoksia, vitamin D3.

\section{KEHAMILAN DENGAN RHEUMATIC HEART DISEASE DI RSUD DR. SOETOMO TAHUN 2012- 2016}

Lalita Eka P. ${ }^{1}$, Khanisyah Erza G. ${ }^{2}$

${ }^{1}$ PPDS-1 Obstetri Ginekologi, FK Universitas

Airlangga - RSUD Dr. Soetomo, Surabaya

${ }^{2}$ Staf Divisi Fetomaternal, Departemen/SMF Obstetri

Ginekologi, FK Universitas Airlangga-RSUD Dr.

Soetomo, Surabaya

*Koresponden: lalita.eka@gmail.com,

$+6281232496922$

Latar belakang: Penyakit jantung akibat Rheumatic Heart Disease (RHD) merupakan masalah yang mendominasi (90\%) penyakit jantung pada kehamilan di dunia. Penyakit jantung merupakan penye- bab non-obstetrik terbanyak kematian ibu di Indonesia, dan RHD merupakan penyebab kematian terbanyak oleh karena penyakit jantung. Tujuan: Menggambarkan karakteristik ibu hamil dengan RHD di RSUD Dr. Soetomo tahun 2012-2016.

Metode: Penelitian retrospektif observasional dengan desain cross sectional. Data sekunder menggunakan rekam medik elektronik periode 1 Januari 2012 - 31 Desember 2016.

Hasil: Didapatkan 93 pasien hamil dengan RHD (dari 198 pasien hamil dengan kelainan jantung) dengan karakteristik: $43 \%$ berumur 21-30 tahun, 79\% multigravida, $67 \%$ pasien datang pada usia kehamilan 28-32 minggu, 85\% dari rujukan luar RSUD Dr Soetomo, $12 \%$ pasien telah dilakukan PTMC, 36\% didominasi Mitral Stenosis. Komplikasi tersering adalah hipertensi pulmonal (33\%), dengan 24\% hipertensi pulmonal berat. $62 \%$ pasien melahirkan perabdominam (39,6\% dengan indikasi hipertensi pulmonal berat). Dari 9 pasien hamil dengan RHD yang meninggal, 7 pasien berasal dari rujukan, 8 pasien belum dilakukan PTMC, 7 pasien dengan hipertensi pulmonal berat dan gagal jantung, dan 6 pasien meninggal saat usia kehamilan 2832 minggu. Didapatkan luaran bayi $71 \%$ dengan berat badan lahir di bawah $2500 \mathrm{~g}$ dan $67 \%$ lahir dengan skor Apgar di bawah 6 .

Kesimpulan: Sebagian besar pasien hamil dengan RHD yang dirawat di RSUD Dr Soetomo berasal dari rujukan dan mengalami komplikasi berat. Jenis kelainan katup didominasi mitral stenosis, dengan komplikasi yang paling banyak hipertensi pulmonal berat. Pemahaman penanganan pasien hamil dengan RHD diperlukan untuk mendapatkan luaran ibu dan bayi yang lebih baik.

Kata kunci: Kehamilan, jantung, rematik.

\section{KARAKTERISTIK KEHAMILAN WANITA DENGAN STENOSIS MITRAL YANG DIAKIBATKAN OLEH PENYAKIT JANTUNG RHEUMATIK DI RSUD DR. SOETOMO SURABAYA TAHUN 2015 - 2017}

Joseph Chandra Relmasira $^{1}$, Budi Wicaksono ${ }^{2}$

${ }^{1}$ Residen Obstetri dan Ginekologi RSUD Dr. Soetomo, , Universitas Airlangga, Surabaya

${ }^{2}$ Konsultan Divisi Fetomaternal, Departemen Obstetri dan Ginekologi RSUD Dr. Soetomo, Universitas Airlangga, Surabaya

Tujuan: Tujuan utama penelitian ini adalah untuk mempelajari luaran maternal dan fetal yang diakibatkan oleh penyakit jantung rheumatik terutama stenosis mitral. 
Metode: Penelitian ini menggunakan metode retrospektif melibatkan 36 kasus wanita hamil dengan penyakit stenosis mitral yang diakibatkan oleh penyakit jantung rheumatik selama periode 3 tahun dari tahun 2015 - 2017. Data luaran maternal dan fetal kemudian kami evaluasi secara deskriptif.

Hasil: Usia kehamilan sebagian besar kasus antara 29 - 34 minggu dengan mayoritas $(61,1 \%)$ mengalami gagal jantung kelas II. Derajat stenosis mitral sebanyak $75 \%$ untuk kasus derajat sedang dan $25 \%$ untuk kasus derajat berat, dengan angka mortalitas sebesar 11,1\% (4 dari 36 kasus). Indikasi perawatan terutama adalah gagal jantung (50\% dari seluruh kasus). Dari hasil penelitian kami, penyakit jantung katup penyerta terbanyak adalah regurgitasi trikuspid (66,67 \%), regurgitasi mitral $(36,11 \%)$ dan regurgitasi aorta $(25$ $\%)$. Usia kehamilan pada saat dilakukan terminasi untuk kasus derajat sedang adalah pada usia lebih dari 34 minggu $(75 \%)$, sedangkan pada derajat berat mayoritas $(52,94 \%)$ dilakukan terminasi dibawah usia kehamilan 34 minggu. Persalinan perabdominam merupakan metode persalinan yang paling banyak dilakukan pada seluruh kasus. Luaran bayi dengan berat lahir kurang dari 2000 gram didapatkan pada kasus stenosis mitral berat $(88,87 \%)$, dan mayoritas bayi memiliki skor APGAR kurang dari 8.

Kesimpulan: Dengan angka kematian sebesar $11,1 \%$ dan lebih dari $90 \%$ kasus stenosis mitral berat akan mengalami gagal jantung selama kehamilan, konseling prakonsepsi dan pertimbangan intervensi bedah pada kasus tertentu merupakan langkah yang sangat penting untuk mencegah komplikasi maternal dan fetal yang diakibatkan oleh penyakit ini selama kehamilan.

Kata kunci: Kehamilan, penyakit jantung rheumatik, stenosis mitral.

\section{PERSALINAN IBU HAMIL DENGAN OBESITAS DI RSUD DR. SOETOMO SURABAYA TAHUN $2017-2018$}

\section{Amirah $^{1}$, Khanisyah Erza Gumilar ${ }^{2}$ \\ ${ }^{1}$ PPDS1 Departemen/SMF Obstetri dan Ginekologi RSUD Dr. Soetomo, Fakultas Kedokteran Universitas Airlangga Surabaya, ${ }^{2}$ Staf Pengajar Departemen/SMF Obstetri dan Ginekologi RSUD Dr. Soetomo, Fakultas Kedokteran Universitas Airlangga Surabaya}

Latar belakang: Obesitas merupakan suatu kondisi akumulasi lemak tubuh yang berlebihan yang dapat membahayakan seseorang dan dianggap sebagai faktor risiko kelima untuk kematian global. Menururut Riset Kesehatan Dasar (Riskesdas) di Indonesia tahun
2018, tingkat obesitas orang dewasa di indonesia meningkat menjadi $21,8 \%$. Prevelensi ini meningkat dari hasil Riskesdas tahun 2013 yang menyebut bahwa angka obesitas di Indonesia hanya mencapai $14,18 \%$.

Tujuan: Melihat komplikasi dari persalinan ibu hamil dengan obesitas di RSUD Dr Soetomo yang merupakan Rumah Sakit terbesar di Indonesia dan pusat rujukan Indonesia Timur.

Metode: Studi ini merupakan studi deskriptif retrospektif. Kasus Persalinan Ibu Hamil dengan obesitas di RSUD Dr. Soetomo pada bulan Januari 2017- Desember 2018. Data pada studi ini diperoleh melalui data register di VK Bersalin dan Poli Hamil RSUD Dr. Soetomo.

Hasil: Angka kejadian persalinan ibu hamil dengan Obesitas di RSUD Dr. Soetomo Surabaya tahun 2017 - 2018 sebanyak 612 Kasus dari 2763 persalinan (22\%), mayoritas penderita berusia 20-34 tahun dan wanita multipara $(70 \%)$. Faktor Komorbid terbesar adalah Preeklampsia (82\%), Diabetes gestasional (10\%), Macrosomia (5\%), dan Kelainan kongenital (3\%). Persalinan Perabdominam terjadi pada mayoritas kasus Obesitas. Terdapat 3 kasus kematian pada persalinan ibu hamil dengan obesitas.

Kesimpulan: Mayoritas ibu hamil dengan Obesitas yang melahirkan di RSUD Dr. Soetomo tahun 2017 - 2018 adalah wanita multipara berusia 22-34 tahun dengan faktor komorbid terbanyak Preeklampsia, DM Gestasional, Macrosomia, dan Kelainan Kongenital. Mayoritas penderita menjalani persalinan perabdominam. Terdapat 3 kasus kematian pada persalinan ibu hamil dengan obesitas.

Kata kunci: Obesitas, hamil, persalinan.

\section{PENGGUNAAN TAMPON EKSTERNAL UTERUS SEBAGAI ALTERNATIF PERTOLONGAN PERTAMA MANAJEMEN PERDARAHAN PASCASALIN DENGAN SUMBER DAYA TERBATAS}

Qonita Prasta Agustia, Arifian Juari, Pande Made Dwijayasa

\section{RSIA Puri Bunda Kota Malang}

Latar belakang: Perdarahan pascasalin (PPS) merupakan penyebab kematian langsung maternal terutama di negara berkembang. Modalitas terapi yang digunakan pada kasus PPS yang gagal dengan pemberian uterotonika adalah dengan pemasangan tampon balon kateter yang telah terbukti efektif. Akan tetapi, tindakan ini memerlukan keahlian dan pengalaman khusus. Dibutuhkan alternatif tindakan pertolongan pertama yang mudah dan efektif serta dapat 
dilakukan oleh semua tenaga kesehatan tanpa pengalaman dan keahlian khusus. Salah satunya adalah dengan menggunakan tampon eksternal uterus, yaitu melakukan pemasangan 'sabuk' benda padat untuk menahan fundus uteri setinggi umbilikus, serta menahan bagian bawah uterus melalui pemasangan tampon kassa padat di dalam vagina. Dengan demikian uterus 'terjepit', sehingga tidak dapat membesar dan terisi darah. Penulis melaporkan pengalaman beberapa kasus PPS yang diatasi dengan menggunakan pemasangan tampon eksternal uterus.

Tujuan: Penelitian ini bertujuan untuk melaporkan kasus penggunaan tampon eksternal uterus sebagai alternatif pertolongan pertama dalam manajemen PPS.

Metode: Penelitian ini merupakan penelitian deskriptif dengan pendekatan serial kasus yang dilaksanakan di RSIA Puri Bunda, Kota Malang. Data diambil dari rekam medis pasien pada periode Januari 2019 - Maret 2019. Pada penelitian ini, sampel diambil dengan teknik consecutive sampling.

Hasil: Pada penelitian ini ditemukan sebanyak 6 kasus PPS dimana tampon eksternal uterus ini berhasil menghentikan perdarahan pada keseluruhan kasus $(100 \%)$ dengan rerata waktu lama penggunaan adalah 85 menit $\mathrm{SD} \pm 39,8$ pada keseluruhan kasus tanpa menimbulkan komplikasi seperti syok ataupun intervensi lanjut seperti operasi. Tatalaksana transfusi pasca perdarahan hanya terjadi pada 1 kasus $(16,6 \%)$ dikarenakan $\mathrm{Hb}$ awal pasien yang rendah (9,6 gr/dL).

Kesimpulan: Penggunaan tampon eksternal uterus ini dapat menjadi alternatif modalitas awal yang mudah pada penanganan pertama PPS. Dibutuhkan penelitian lebih lanjut dengan jumlah sampel yang lebih besar untuk mengetahui efektivitas penggunaan tampon eksternal uterus ini.

Kata kunci: PPS, tampon eksternal uterus.

\section{OBSTETRI GINEKOLOGI SOSIAL}

\section{KORELASI ASUPAN ZAT BESI DAN PROTEIN DENGAN KADAR FERRITIN SERUM IBU HAMIL DI KABUPATEN WALED DAN SUKABUMI}

Lani Gumilang ${ }^{1}$, Sefita Aryuti Nirmala ${ }^{1}$, Puspa Sari ${ }^{1}$, Mochamad Ari Wibowo ${ }^{2}$, Raden Tina Dewi Judistiani ${ }^{1}$, Delita Prihatni ${ }^{3}$

${ }^{1}$ Departemen Ilmu Kesehatan Masyarakat Fakultas
Kedokteran Universitas Padjadjaran, ${ }^{2}$ Fakultas
Kedokteran Universitas Padjadjaran, ${ }^{3}$ Departemen
Patologi Klinik Fakultas Kedokteran Universitas Padjadjaran

Latar Belakang: Ferritin adalah protein penyimpanan zat besi yang juga terdapat secara ekstraseluler dalam serum, dimana ferritin berfungsi sebagai penanda klinis status simpanan zat besi tubuh

Tujuan: Mengetahui hubungan asupan protein dan zat besi dengan kadar ferritin serum ibu hamil trimester pertama.

Bahan dan Metode Penelitian potong lintang dengan desain analisis korelasi dilakukan sebagai bagian dari penelitian kohor ibu hamil dengan judul Peran Vitamin D dalam Menurunkan Angka Kematian Ibu dan Bayi di Jawa Barat. Jumlah sampel disesuaikan dengan alokasi dana yang tersedia, dan berhasil direkrut sebanyak $150 \mathrm{ibu}$ hamil secara konsekutif dari wilayah kerja RSUD Al Mulk dan RSUD Waled. Analisis korelasi dilakukan dengan uji non parametrik: (1) analisis bivariat dengan uji korelasi gamma (2) analisis multivariat dengan uji regresi ordinal dengan Interval Kepercayaan $95 \%$.

Hasil: Hubungan antara asupan zat besi dengan kadar ferritin serum diperoleh $p=0,009, \quad \mathrm{OR}=5,181$; $\mathrm{IK}=-(2,881-0,410)$. Hubungan antara asupan protein dengan kadar ferritin serum diperoleh $p=0,041$, $\mathrm{OR}=0,142 ; \mathrm{IK}=(0,084-3,823)$.

Simpulan: Terdapat hubungan yang bermakna, baik antara asupan protein maupun antara asupan zat besi dengan kadar ferritin serum. Asupan protein dan zat besi dengan kategori kurang berhubungan secara bermakna dengan kadar ferritin serum kurang sebagai faktor risiko.

Kata kunci: Zat besi, Protein, Ferritin Serum

\section{MENENTUKAN CUT-OFF POINT KENAIKAN BERAT BADAN SELAMA KEHAMILAN UNTUK MEMPREDIKSI BAYI BERAT LAHIR RENDAH PADA BAYI CUKUP BULAN DARI IBU DENGAN INDEKS MASSA TUBUH NORMAL}

Rosinta Pratiwi, Vicky Admiral Aprizano, Risanto Siswosudarmo

Departemen Obstetri dan Ginekologi

Fakultas Kedokteran, Universitas Gadjah Mada/RS Sardjito, Yogyakarta

Tujuan: Untuk menentukan cut-off point kenaikan berat badan selama kehamilan hubungannya dengan bayi berat lahir rendah pada bayi cukup bulan dari ibu dengan indeks masa tubuh normal. 
Metode: Merupakan penelitian potong lintang yang dilakukan di Rumah Sakit Sardjito dan 9 rumah sakit afiliasi di Provinsi Jawa Tengah. Penelitian ini memasukkan 619 perempuan yang memenuhi kriteria kelayakan. Digunakan kurva ROC dan chi-square test untuk analisis statistik.

Hasil: Rerata dan deviasi standar index massa tubuh, kenaikan berat badan selama kehamilan, dan berat lahir bayi masing-masing adalah 21,28 $\pm 1,87$ $\mathrm{kg} / \mathrm{m}^{2}, 11,62 \pm 4,33 \mathrm{~kg}$ dan $3041,61 \pm 385,70$ gram. Jumlah bayi berat lahir rendah $<2.500$ gram adalah $6 \%$. Kurva ROC menunjukkan bahwa cut-off point kenaikan berat badan selama kehamilan dan kaitannya dengan bayi berat lahir rendah adalah $8,5 \mathrm{~kg}$. Analisis lanjut menunjukkan angka bayi berat lahir rendah sebanyak $21,1 \%$ untuk kenaikan berat badan selama kehamilan $<8,5 \mathrm{~kg}$ dibandingkan dengan $1,3 \%$ untuk kenaikan berat badan selama kehamilan $\geq 8,5 \mathrm{~kg}$. Risiko terjadinya bayi berat lahir rendah pada ibu dengan kenaikan berat badan selama kehamilan $\geq 8,5 \mathrm{~kg}$ lebih tinggi secara signifikan (Resiko Relatif 16,59; $95 \%$ Interval Kepercayaan 7,06 - 38,98).

Kesimpulan: Cut-off point kenaikan berat badan selama kehamilan untuk menghindari kejadian bayi berat lahir rendah pada banyi cukup bulan pada ibu dengan index massa tubuh normal adalah $8,5 \mathrm{~kg}$. Risiko memiliki bayi berat lahir rendah adalah 16,59 kali lebih besar jika kenaikan berat badan selama kehamilan di bawah $8,5 \mathrm{~kg}$.

Kata kunci: bayi berat lahir rendah, indeks masa tubuh normal, kenaikan berat badan selama kehamilan.

\section{THREE STRATEGIC AREAS INTERVENTION WITH THEIR RESPECTIVE INDICATORS HAVE BEEN IDENTIFIED THAT MAY BE CONSIDERED KEY DRIVERS REDUCTION OF MATERNAL MORTALITY IN INDONESIA}

\section{Gulam Gumilar, Sardjana Atmadja}

\section{Department of Obstetrics and Gynecology Syarif Hidayatullah State Islamic University Jakarta}

Objectives: The main objective is to assess the progress made in reducing maternal morbidity and mortality in Indonesia and to help to implement the corrective measures needed at implement the corrective measures needed at different stages. This requires strengthening of the on going monitoring system.

Material and Method: Data will be verified using sources such as an Operational Research System Analysis (ORSA), and was carried out in governmentowned type $\mathrm{C}$ hospitals in Indonesia. The main variables observed were a) working ethos b) blood facilities c) communication facilities. Three strategic areas to accurate the reduction of maternal mortality, interventions with their respective indicators have been indentified and prioritized.

Results: There are 3 determinants factors that may be considered key drivers in the reduction of maternal mortality, there are also specific potential measures directly aimed at reducing maternal mortality that can be adopted in the health sector. The contribution of working ethos variable is $36,8 \%$, the contribution of blood facilities is $36,7 \%$ and the contribution of communication facilities is $26,3 \%$ in Clinical Management model in order to reduce maternal mortality in government-owned type $\mathrm{C}$ hospitals.

Conclusion: Based on the official data provided by Minister of Health Indonesia, the region's maternal mortality rates decreased $35 \%$ in late 2015.Approximately $90 \%$ of maternal mortality could be prevented using knowledge already available in this country.

Key words: working ethos variable, the contribution of blood facilities is 36 , the contribution of communication facilities, Clinical Management model.

\section{HEALTH POLICY DECISION MAKING IN SAFE MOTHERHOOD REGIONAL ISSUE}

Gulam Gumilar, Sardjana Atmadja

Department of Obstetrics and Gynecology Faculty of Medicine Islamic State of Syarif Hidayatullah University Jakarta

Objectives: To reduce maternal and morbidity in half by the 2017 , the safe motherhood initiative was launched

Methods: Mobilizing political will, involving community members,sharing information,sharing the media and sensitizing men to the issues

Results: More than 365 /100.000 life birth women die every year because of complications related to pregnancy and child birth. The disparity between maternal death rates in developing and developed countries is greater than for any other common category of death. Poor maternal health during pregnancy is directly linked to poor health in the infant. Therefore, a mother's health and survival continues to be critically important throughout a child's life. Pregnant women and children suffer first and most under poor socioeconomic conditions. The success of safe motherhood initiative depends on the active participation of a wide range of individuals and organizations who can contribute ideas, skills, and funds, because the problem stems not only from inadequate health services, but mostly also from the 
social, cultural, and economic environment in which women live.

Conclusions: Health policy decision making in safe motherhood at least should be based on the assessment of Maternal Health situation and health services and the assessment of sociocultural aspects of safe motherhood of each region.

Key words: Maternal health, infant health and child survival, health policy in safe motherhood

\section{DETERMINAN RENDAHNYA AKSEPTOR KELUARGA BERENCANA (KB) DI WILAYAH PUSKESMAS WAKAI KABUPATEN TOJO UNA- UNA TAHUN 2018}

\section{Sepfrita Katerina Aftabuddin}

\section{Puskesmas Wakai, Kabupaten Tojo Una-Una, Sulawesi Tengah}

Latar belakang: Modal utama suatu negara dalam menunjang ekonominya adalah jumlah penduduk. Pertumbuhan penduduk yang tidak terkontrol menjadi masalah besar bagi suatu negara. Penggunaan kontrasepsi efektif dalam menurunkan angka populasi namun kesadaran masyarakat masih sangat rendah

Tujuan: Tujuan dari penelitian ini adalah menganalisis faktor determinan yang menyebabkan rendahnya akseptor keluarga berencana di wilayah Puskesmas Wakai Kabupaten Tojo Una-una.

Metode: Penelitian ini menggunakan analitik observasional dengan pendekatan cross sectional. Pengambilan sampel menggunakan teknik simple random sampling dan dilakukan analisis univariat, bivariat dan multivariat.

Hasil: Hasil menunjukkan bahwa $80,88 \%$ responden tidak menggunakan kontrasepsi dan $19,12 \%$ responden yang menggunakan kontrasepsi. Analisis bivariat menunjukkan bahwa faktor yang mempengaruhi penggunaan kontrasepsi adalah faktor usia ( $p$ : $0,114)$, sosial budaya $(p: 0,003)$, rasa aman $(p: 0,000)$, pengetahuan $(p: 0.767)$, paritas $(p: 0,000)$, perencaan kehamilan ( $p$ : 0,000) dan faktor ekonomi ( $p: 0,513)$ kemudian dilakukan analisis multivariat.

Kesimpulan: Faktor sosial budaya, rasa aman, paritas dan perencaan kehamilan merupakan faktor yang ditemukan mempengaruhi rendahnya akseptor keluarga berencana di wilayah Puskesmas Wakai.

Kata kunci: Akseptor, Keluarga Berencana, Kontrasepsi

\section{KEGAGALAN ANTENATAL CARE DALAM MENDETEKSI PREEKLAMPSIA PADA KASUS EKLAMPSIA: LAPORAN KASUS DARI KETAPANG, KALIMANTAN BARAT}

Setiawan V, Sugiarto A, Avriyani R, Hidayat F

RSUD Agoesdjam, Ketapang, Kalimantan Barat, Indonesia

Latar Belakang: Preeklampsia dan eklampsia adalah salah satu penyebab utama mortalitas dan morbiditas maternal dan perinatal di seluruh dunia. Insiden preeklampsia di negara berkembang tujuh kali lebih tinggi daripada di negara maju. Hal ini disebabkan rendahnya kualitas dan kuantitas antenatal care dalam upaya deteksi dan penanganan terhadap risiko terjadinya preeklampsia.

Laporan Kasus: Perempuan, 28 tahun, hamil ketiga datang ke rumah sakit dengan kejang tiga kali dan tekanan darah 190/110 $\mathrm{mmHg}$ disertai proteinuria (+3) saat usia kehamilan 39 minggu. Keluhan nyeri kepala dan pandangan kabur muncul dua hari sebelumnya namun diabaikan. Pasien hanya kontrol kehamilan sebanyak lima kali hingga usia kehamilan 34 minggu dan tidak ditemukan tekanan darah tinggi serta pemeriksaan protein urine tidak pernah dilakukan. Pasien memiliki riwayat kejang pada kehamilan pertama enam tahun yang lalu. Pemeriksaan ultrasonografi pada usia kehamilan 34 minggu menunjukkan janin tunggal intrauterin, plasenta di posterior, letak kepala, dan taksiran berat janin 2100 gram. Terminasi kehamilan dilakukan dengan seksio sesarea. Lahir bayi perempuan langsung menangis dengan berat 3000 gram dan panjang $46 \mathrm{~cm}$. Pasien dipulangkan pada hari ke-6 dengan kondisi stabil dan tekanan darah normal.

Diskusi: World Health Organization merekomendasikan delapan kali kunjungan antenatal care selama kehamilan dan lima diantaranya pada trimester ketiga, karena $90 \%$ kasus preeklampsia terjadi diatas usia kehamilan 34 minggu. Pada fasilitas kesehatan primer dengan sumber daya terbatas, diharapkan preeklampsia dapat dideteksi dengan identifikasi gejala, pengukuran tekanan darah, protein urine, dan berat badan. Pada fasilitas kesehatan yang lebih tinggi dapat disertai dengan pemeriksaan jumlah trombosit dan serum kreatinin. Diharapkan dengan standar pemeriksaan seperti ini tidak ada kasus preeklampsia yang tidak terdeteksi, terutama pada pasien yang berisiko tinggi.

Kesimpulan: Preeklampsia dapat dideteksi mulai dari fasilitas dengan sumber daya terbatas jika menerapkan antenatal care dengan kualitas dan kuantitas yang baik. Perlu adanya standar pemeriksaan dalam mendeteksi preeklampsia yang mudah diterapkan 
mulai dari fasilitas kesehatan primer serta edukasi untuk melakukan antenatal care sesuai jadwal.

Kata Kunci: preeklampsia, antenatal care

\section{STUDI EPIDEMIOLOGI: RUJUKAN TERLAMBAT PADA KELAINAN SPEKTRUM PLASENTA AKRETA PADA PUSAT RUJUKAN TERSIER PLACENTA AKRETA TAHUN 2014- 2018}

Diana Apriliyana Nur ${ }^{1}$, Rizki Pranadyan², Rozi Aditya ${ }^{2}$

${ }^{I}$ PPDS-I Departemen/SMF Obstetri dan Ginekologi RSUD dr. Soetomo, Fakultas Kedokteran Universitas Airlangga Surabaya, ${ }^{2}$ Staf Pengajar Departemen/SMF Obstetri dan Ginekologi RSUD dr. Soetomo, Fakultas Kedokteran Universitas Airlangga Surabaya

Latar belakang: Kehamilan dengan kelainan spektrum plasenta akreta merupakan masalah obstetrik yang jumlahnya semakin meningkat setiap tahun. Kasus ini memerlukan penanganan secara tepat, cepat dan multidisiplin. Patogenesis yang belum jelas, belum adanya modalitas diagnostik yang pasti, serta belum adanya konsensus nasional mengenai kasus ini menyebabkan angka rujukan terlambat yang menimbulkan morbiditas dan resiko mortalitas masih cukup tinggi.

Tujuan: Mengetahui karakteristik dan luaran maternal kasus rujukan terlambat kelainan spektrum plasenta akreta di RSUD dr. Soetomo Surabaya tahun 2014- 2018.

Metode: Penelitian retrospektif dengan data sekunder dari rekam medis (RM) di RSUD Dr. Soetomo Surabaya tahun 2014-2018

Hasil: Kasus kelainan spektrum plasenta akreta pada periode Januari 2014- Desember 2018 sebanyak 163 kasus, sebanyak 123 kasus merupakan rujukan tepat waktu sedangkan 40 kasus merupakan rujukan terlambat. Dari 40 kasus rujukan terlambat, sebanyak $37,5 \%$ merupakan rujukan post partum. Berdasarkan faktor resiko didapatkan $84 \%$ memiliki riwayat SC, $4 \%$ dengan riwayat kuret dan $12 \%$ dengan riwayat SC disertai kuretase. Pada kasus rujukan post partum, tujuh kasus dirujuk karena didapatkan perdarahan post SC dan dua kasus dirujuk dengan plasenta insitu, lima kasus internal bleeding setelah caesarean histerektomi. Hampir semua kasus rujukan post partum dilakukan operasi ulang dengan jumlah perdarahan durante operasi yang lebih banyak daripada sebelumnya. Didapatkan 5 kasus kematian maternal yang disebabkan oleh syok hipovelemik irreversible.

Berdasarkan asal rujukan, pasien yang dirujuk dalam kondisi hamil $44 \%$ berasal dari kota Surabaya, sedangkan pasien yang dirujuk post partum 33,33\% berasal dari rujukan kota Surabaya. Berdasarkan jenis rujukan, kasus rujukan terlambat dalam kehamilan sebanyak $60 \%$ kasus merupakan rujukan gawat darurat dan pada kasus yang rujukan post partum sebanyak 93,3\% merupakan rujukan gawat darurat.

Kesimpulan: Kasus rujukan terlambat kelainan spektrum plasenta akreta di RSUD dr. Soetomo Surabaya masih didapatkan jumlah yang tinggi. Sosialisasi dan pelatihan mengenai managemen kelainan spektrum plasenta akreta masih dibutuhkan.

Kata Kunci: akreta, rujukan terlambat

\section{KORELASI ASUPAN ZAT BESI DAN PROTEIN DENGAN KADAR FERRITIN SERUM IBU HAMIL DI KABUPATEN WALED DAN SUKABUMI}

Lani Gumilang ${ }^{1}$, Sefita Aryuti Nirmala ${ }^{1}$, Puspa Sari ${ }^{1}$, Mochamad Ari Wibowo ${ }^{2}$, Raden Tina Dewi Judistiani ${ }^{1}$, Delita Prihatni ${ }^{3}$

${ }^{1}$ Departemen Ilmu Kesehatan Masyarakat Fakultas Kedokteran Universitas Padjadjaran

${ }^{2}$ Fakultas Kedokteran Universitas Padjadjaran

${ }^{3}$ Departemen Patologi Klinik Fakultas Kedokteran Universitas Padjadjaran

Latar belakang: Ferritin adalah protein penyimpanan zat besi yang juga terdapat secara ekstraseluler dalam serum, dimana ferritin berfungsi sebagai penanda klinis status simpanan zat besi tubuh

Tujuan: Mengetahui hubungan asupan protein dan zat besi dengan kadar ferritin serum ibu hamil trimester pertama.

Metode: Potong lintang dengan desain analisis korelasi dilakukan sebagai bagian dari penelitian kohor ibu hamil dengan judul Peran Vitamin D dalam Menurunkan Angka Kematian Ibu dan Bayi di Jawa Barat. Jumlah sampel disesuaikan dengan alokasi dana yang tersedia, dan berhasil direkrut sebanyak $150 \mathrm{ibu}$ hamil secara konsekutif dari wilayah kerja RSUD Al Mulk dan RSUD Waled. Analisis korelasi dilakukan dengan uji non parametrik: (1) analisis bivariat dengan uji korelasi gamma (2) analisis multivariat dengan uji regresi ordinal dengan Interval Kepercayaan 95\%.

Hasil: Hubungan antara asupan zat besi dengan kadar ferritin serum diperoleh $\mathrm{p}=0,009, \mathrm{OR}=5,181$; $\mathrm{IK}=-(2,881-0,410)$. Hubungan antara asupan protein dengan kadar ferritin serum diperoleh $\mathrm{p}=0,041, \mathrm{OR}=$ 0,$142 ; \mathrm{IK}=(0,084-3,823)$.

Kesimpulan: Terdapat hubungan yang bermakna, baik antara asupan protein maupun antara asupan zat besi dengan kadar ferritin serum. Asupan protein dan 
zat besi dengan kategori kurang berhubungan secara bermakna dengan kadar ferritin serum kurang sebagai faktor risiko.

Kata kunci: Zat besi, protein, ferritin serum.

\section{PERBANDINGAN FAKTOR DETERMINAN DAN LUARAN PREEKLAMSI DI RUMAH SAKIT HASAN SADIKIN PERIODE SEBELUM DAN SAAT PROGRAM JAMINAN KESEHATAN NASIONAL DILAKSANAKAN}

Irene Leha

\section{Departemen Obstetri dan Ginekologi Fakultas Kedokteran Universitas Padjadjaran, Rumah Sakit Dr. Hasan Sadikin Bandung}

Latar belakang: Sindrom preeklamsi berarti hipertensi dan proteinuria pada perempuan hamil yang sebelumnya normotensif setelah kehamilan 20 minggu atau pada periode pascasalin dini. Sindrom preeklamsi (preeklamsi maupun hipertensi kronis yang diperberat preeklamsi) merupakan masalah kedokteran yang serius dan memiliki tingkat kompleksitas yang tinggi. Penyakit hipertensi terjadi pada 5-10\% kehamilan, bersama perdarahan dan infeksi membentuk trias yang mematikan yang berperan besar dalam angka morbiditas dan mortalitas ibu. Sekitar 18\% dari seluruh kematian ibu di seluruh dunia disebabkan oleh hipertensi dalam kehamilan (HDK), dengan perkiraan 62.000 - 77.000 kematian per tahun. Untuk setiap wanita yang meninggal, diperkirakan bahwa 20 orang lain menderita morbiditas berat atau disability. Sekitar $57,5 \%$ penyebab kematian ibu di RSUP Dr. Hasan Sadikin tahun 20092013 adalah preeklamsi dan eklamsi. Penyakit hipertensi dalam kehamilan merupakan penyebab tersering kedua morbiditas dan mortalitas perinatal. Suatu penelitian systematic review oleh Comfort dkk yang menilai hubungan antara jaminan kesehatan dengan luaran kesehatan ibu mengemukakan bahwa dengan memiliki jaminan kesehatan dapat memperbaiki derajat kesehatan ibu melalui peningkatan penggunaan layanan kesehatan ibu dan perbaikan kualitas pelayanan kesehatan. Sejak tanggal 1 Januari 2014 di Indonesia telah diberlakukan program Jaminan Kesehatan Nasional (JKN) yang penanggulangan biaya kesehatannya ditangani oleh Badan Penyelenggara Jaminan Sosial (BPJS) Kesehatan. Perbedaan pola penanggulangan biaya kesehatan ini diduga akan berdampak pada pola penyakit dan derajat kesehatan di Indonesia termasuk preeklamsi di RSUP Dr. Hasan Sadikin Bandung. Seberapa besarkah dampak yang terjadi? Sampai saat ini belum pernah dievaluasi.
Tujuan: Mencari perbedaan faktor determinan (karakteristik dan faktor risiko), morbiditas dan mortalitas ibu dan bayi dalam kasus preeklamsi pada periode sebelum dan saat program Jaminan Kesehatan Nasional dilaksanakan.

Metode: Rancangan penelitian ini adalah studi cross-sectional terhadap data sekunder untuk menganalisis karakteristik faktor risiko, morbiditas dan mortalitas pada kejadian preeklamsi di RSUP Dr. Hasan Sadikin periode Maret hingga September 2012 dan 1 Januari 2016 hingga 31 Desember 2017. Penelitian ini dilakukan di RSUP Dr. Hasan Sadikin Bandung pada bulan Februari hingga Mei 2018.

Hasil: Didapatkan perbedaan yang bermakna ( $\mathrm{P}<$ 0,05) pada karakteristik dan faktor risiko subjek penelitian. Didapatkan peningkatan angka seksio sesarea pada kasus preeklamsi ( $\mathrm{p}<0,001)$. Tidak ditemukan perbedaan yang bermakna pada angka kematian ibu dengan kasus preeklamsi $(\mathrm{p}=0,366)$. Tidak terdapat perbedaan yang bermakna pada hasil luaran perinatal pada subjek penelitian dari segi skor APGAR, kejadian stillbith dan kematian neonatal dini.

Kesimpulan: Pada periode saat program JKN dilaksanakan terdapat perbedaan karakteristik dan faktor risiko ibu preeklamsi, serta terdapat peningkatan angka seksio sesarea. Tidak didapatkan perbedaan angka mortalitas ibu dan luaran (morbiditas dan mortalitas) bayi.

Kata kunci: Preeklamsi, jaminan kesehatan nasional, luaran ibu dan bayi.

\section{ANALISIS KEAKURATAN DIAGNOSIS DAN CODING KASUS SEKSIO SESAREA KELAS III BPJS KESEHATAN TERHADAP SELISIH KLAIM INA CBGS RSUPN DR. CIPTO MANGUNKUSUMO}

Imam Rahmadi

Department of Obstetrics and Gynecology, Faculty of Medicine Universitas Indonesia Dr. Cipto

Mangunkusumo Hospital, Jakarta

Latar belakang: Kementerian Kesehatan Republik Indonesia sejak Januari 2014 telah menerapkan mekanisme pembayaran prospektif dalam rangka menekan biaya pelayanan kesehatan yang cenderung naik akibat sistem sebelumnya yang bersifat retrospektif. Sistem pembayaran ini dikenal sebagai Indonesian Case Based Groups (INA CBGs). Salah satu pembiayaan tindakan yang mempunyai kecenderungan kenaikan adalah seksio sesarea

Tujuan: Keakuratan koding diagnosis dan prosedur medis serta faktor-faktor yang mempengaruhi 
terjadinya perbedaan klaim INA CBGs RSUPN Dr. Cipto Mangunkusumo.

Metode: Deskriptif observasional, simple random sampling, perhitungan kuantitatif menggunakan data retrospektif, data resume medis elektronik pasien.

Hasil: Didapatkan $43 \%$ coding diagnosis utama oleh dokter tidak sesuai. $62 \%$ koding diagnosis sekunder DPJP tidak sesuai, namun mengalami perbaikan setelah dilakukan reseleksi dan entry data oleh coder sebesar 97\%. Kesesuaian coding prosedur medis sebesar $98 \%$ dan $100 \%$ grouper yang sesuai, tapi masih ditemukan kesalahan coding dan severity level sebesar 27,7\%. Akibat ketidaksesuaian coding dan grouping severity level menimbulkan kerugian Rp 584.099 per kasus pada tahun 2016, dan bila dihitung berdasarkan biaya riil terhadap klaim INA CBGs maka didapatkan selisih negatif yang jauh lebih besar yaitu Rp 17.263.241 per kasus.

Kesimpulan: Penyebab kerugian klaim RSUPN Dr. Cipto Mangunkusumo diakibatkan ketidakcermatan dokter dalam penulisan resume medis elektronik dan coding, serta diperburuk oleh ketidaktelitian coder dalam melakukan reseleksi dan prosedur entry coding.

Kata kunci: Analisis keakuratan, seksio sesarea, BPJS, INA CBGs.

\section{BUDAYA SE'I DAN TATOBI SERTA AKIBAT YANG TERJADI PADA IBU NIFAS DAN BAYI BARU LAHIR (BBL) PADA MASYARAKAT SUKU TIMOR DI KECAMATAN AMANATUN SELATAN, NUSA TENGGARA TIMUR}

Heldasari Sianturi

\section{Puskesmas Oinlasi, Kecamatan Amanatun Selatan, NTT}

Latar belakang: Masyarakat Suku Timor terkenal dengan beraneka ragam budaya yang masih melekat hingga saat ini. Salah satunya adalah budaya se'i dan tatobi. Budaya se'i dan tatobi adalah proses perawatan ibu paska bersalin selama 40 hari yang dilakukan di dalam ume'k bubu (rumah bulat). Se'i adalah panggang dengan bara api dan tatobi adalah kompres air panas. Masyarakat suku Timor percaya dengan budaya tersebut dapat mengeluarkan 'darah kotor' masa nifas, mengembalikan kekuatan dan bentuk tubuh setelah melahirkan.

Tujuan: untuk mengidentifikasi akibat-akibat yang bisa terjadi dari budaya Se'i dan Tatobi pada masyarakat suku Timor.

Metode: jenis penelitian deskriptif dengan pendekatan kualitatif melalui Foccus Group Discussion (FGD).
Hasil: Data Januari 2018-April 2019: jumlah ibu hamil yang melahirkan di fasilitas kesehatan sebanyak 351 orang dan non-faskes 76 orang. Dari $351 \mathrm{ibu}$ didapatkan 22 yang melakukan sei dan tatobi di rumah bulat; melakukan sei dan tatobi di rumah besar/kamar tidur sebanyak 192 orang; hanya melakukan tatobi saja sebanyak 35 orang; tidak melakukan sei dan tatobi sebanyak 102 orang. Dari 76 ibu yang melahirkan nonfaskes didapatkan 46 orang melakukan sei dan tatobi di rumah bulat dan 30 orang melakukan sei dan tatobi di rumah besar/kamar tidur. Akibat yang terjadi dan dilaporkan adalah ISPA sebanyak 18 orang, luka bakar 7 orang, dehidrasi 11 orang dan syok hipovolemik 2 orang. Bayi baru lahir didapatkan kasus luka bakar 1 orang, bronkopneumonia 4 orang dan kematian 1 orang.

Kesimpulan: Akibat yang nyata terjadi dari budaya sei dan tatobi belum bisa merubah pola pikir masyarakat tentang budaya tersebut.

Kata kunci: Budaya Se'i dan tatobi, ibu nifas dan BBL, suku timor.

\section{TELAAH PENCAPAIAN IPSG (INTERNATIONAL PATIENT SAFETY GOALS) OLEH TENAGA KESEHATAN DI DEPARTEMEN OBSTETRI DAN GINEKOLOGI RSCM (RUMAH SAKIT CIPTO MANGUNKUSUMO) DAN FAKTOR-FAKTOR YANG MEMENGARUHINYA}

\section{J.M Seno Adjie}

Latar belakang: Masalah keselamatan pasien adalah masalah yang ada di seluruh belahan dunia. Pada tahun 2011 terdapat sebuah penelitian di RSCM yang menilai kualitas pelayanan dari dimensi keandalan, daya tanggap, jaminan, empati dan keberwujudan. Dari penelitian tersebut diperoleh bahwa 73,2\% dari 112 pasien yang diteliti menyatakan tidak puas dengan pelayanan yang diberikan. Untuk meningkatkan kualitas pelayanannya, RSCM sudah mengikuti akreditasi JCI pada 2013

Tujuan: Mengetahui pencapaian IPSG oleh tenaga kesehatan di departemen obstetri dan ginekologi RSCM dan faktor-faktor yang memengaruhinya.

Metode: Penelitian ini menggunakan disain potong lintang di RSCM dengan menggunakan kuisioner. Responden yang memenuhi kriteria inklusi dicatat dan data yang diperoleh diolah secara statistik.

Hasil: Dari data yang dikumpulkan sejak Mei hingga Agustus 2018 didapatkan pencapaian IPSG oleh tenaga kerja di departemen obstetri dan ginekologi di RSCM yaitu untuk IPSG 1 92,4\%, IPSG 2 94,4\%, IPSG $395,1 \%$, IPSG $488,7 \%$, IPSG $588,7 \%$ dan IPSG 6 $84,9 \%$. Lama bekerja di unit yang bersangkutan, lama kerja sejak lulus, harapan gaji yang diterima, supervisi 
yang dirasakan oleh tenaga kesehatan dan tingkat pendidikan terakhir tenaga kesehatan memiliki hubungan yang bermakna terhadap pencapaian IPSG.

Kesimpulan: Pencapaian IPSG oleh tenaga kesehatan di departemen obstetri dan ginekologi RSCM adalah cukup tinggi. Pencapaian yang cukup tinggi tersebut berhubungan dengan beberapa karakteristik, faktor psikologis dan faktor organisasi.

Kata kunci: IPSG, patient safety, RSCM.

\section{DETERMINAN RENDAHNYA AKSEPTOR KELUARGA BERENCANA (KB) DI WILAYAH PUSKESMAS WAKAI KABUPATEN TOJO UNA- UNA TAHUN 2018}

\section{Sepfrita Katerine Aftabuddin}

Latar belakang: Modal utama suatu negara dalam menunjang ekonominya adalah jumlah penduduk. Pertumbuhan penduduk yang tidak terkontrol menjadi masalah besar bagi suatu negara. Penggunaan kontrasepsi efektif dalam menurunkan angka populasi namun kesadaran masyarakat masih sangat rendah.

Tujuan: Tujuan dari penelitian ini adalah menganalisis faktor determinan yang menyebabkan rendahnya akseptor keluarga berencana di wilayah Puskesmas Wakai Kabupaten Tojo Una-una.

Metode: Penelitian ini menggunakan analitik observasional dengan pendekatan cross sectional. Pengambilan sampel menggunakan teknik simple random sampling dan dilakukan analisis univariat, bivariat dan multivariat.

Hasil: Hasil menunjukkan bahwa $80,88 \%$ responden tidak menggunakan kontrasepsi dan $19,12 \%$ responden yang menggunakan kontrasepsi. Analisis bivariat menunjukkan bahwa faktor yang mempengaruhi penggunaan kontrasepsi adalah faktor usia (p: 0,114), sosial budaya (p: 0,003), rasa aman (p: 0,000), pengetahuan (p: 0.767), paritas (p: 0,000), perencaan kehamilan (p: 0,000) dan faktor ekonomi (p: 0,513) kemudian dilakukan analisis multivariat.

Kesimpulan: Faktor sosial budaya, rasa aman, paritas dan perencaan kehamilan merupakan faktor yang ditemukan mempengaruhi rendahnya akseptor keluarga berencana di wilayah Puskesmas Wakai.

Kata kunci: Akseptor, keluarga berencana, kontrasepsi.

\section{HUBUNGAN SISTEM DOKTER PENANGGUNG JAWAB PELAYANAN (DPJP) TERHADAP ANGKA KOMPLIKASI PEMBEDAHAN}

\section{OBSTETRI DAN GINEKOLOGI TERENCANA DI RS CIPTO MANGUNKUSUMO JAKARTA}

Finna Hardjono, Andrijono

Departemen Obstetri dan Ginekologi, RS

Ciptomangunkusumo, Jakarta, Indonesia

Latar belakang: Tindakan pembedahan atau operasi merupakan tindakan yang sangat berkaitan erat dengan bidang obstetri dan ginekologi. Masing-masing kasus akan bervariasi dan memiliki resiko dan jenis komplikasi tersendiri. Sistem pelayanan di RSCM saat ini telah mengalami perubahan pengaturan menjadi sistem Dokter Penanggung Jawab Pelayanan (DPJP) sejak tahun 2009. Belum ada penelitian di Indonesia yang menyimpulkan bagaimana pengaruh sistem DPJP terhadap angka komplikasi pembedahan.

Tujuan: Penelitian ini bertujuan untuk mengetahui insidens kasus komplikasi dalam tindakan pembedahan obstetri dan ginekologi di RSCM pada masa sebelum dan sesudah DPJP

Metode: Penelitian dekriptif observasional ini dilakukan di RS Cipto Mangunkusumo sejak Desember 2017 hingga Februari 2018. Data sebelum sistem DPJP yaitu tahun 2007-2008 dan sistem DPJP yaitu tahun 2010-2011. Data tindakan pembedahan dijabarkan secara deskriptif dan insiden morbiditas diolah dengan analisis bivariat.

Hasil: Insidens terjadinya komplikasi pembedahan di RSCM pada masa sebelum versus sesudah DPJP adalah sebesar $2,7 \%$ versus $1,01 \%$. Perubahan sistem menjadi DPJP di RSCM mempunyai resiko komplikasi yang lebih rendah yaitu sebanyak 22 dan pada sesudah DPJP menjadi 18 kasus bermakna secara statistik dengan nilai $(\mathrm{p}<0,05)$ dengan OR 0,41. Pada kasus ginekologi, sistem DPJP bermakna secara statistik ( $<<0,05)$ dengan nilai OR 0,23 . Untuk onkologi tidak ada perbedaan bermakna, morbiditas pada kelompok pra DPJP sebesar $4,1 \%$ dan pada DPJP sebesar $2 \%$ dengan nilai p 0,07. Dari jenis pembedahan laparotomi, system DPJP bermakna secara statistik $(\mathrm{p}<0,05)$ dengan nilai OR 0,41 .

Kesimpulan: Perubahan sistem menjadi DPJP di RSCM mempunyai resiko komplikasi yang lebih rendah dibandingkan dengan sistem sebelum DPJP.

Kata kunci: Sistem DPJP system, komplikasi operasi, operasi obstetri ginekologi.

\section{KARAKTERISTIK WANITA MENOPAUSE YANG MENGALAMI PROLAPSUS UTERI DI DAERAH PESISIR SULAWESI TENGGARA}


Juminten Saimin ${ }^{1}$, Indria Hafizah ${ }^{2}$, Nina Indriyani ${ }^{2}$, Ashaeryanto $^{2}$, Satrio Wicaksono ${ }^{2}$

\section{${ }^{I}$ Bagian Obstetri dan Ginekologi Fakultas Kedokteran Universitas Halu Oleo, ${ }^{2}$ Bagian Biomedik Fakultas Kedokteran Universitas Halu Oleo}

Latar belakang: Prolapsus uteri merupakan salah satu masalah kesehatan reproduksi, terutama pada masa menopause. Prolapsus uteri dapat mempengaruhi aktivitas dan kualitas hidup wanita. Wanita dengan prolapsus uteri dapat mengalami masalah fisik dan psikososial.

Tujuan: Mengetahui karakteristik wanita menopause yang mengalami prolapsus uteri di daerah pesisir Sulawesi Tenggara.

Metode: Penelitian ini bersifat deskriptif analitik yang dilakukan di Poliklinik Kandungan Alfa Kendari pada bulan Januari sampai Desember 2017. Diagnosis prolapsus uteri berdasarkan sistem Pelvic Organ Prolapse Quantification (POP-Q). Sampel diambil secara consecutive sampling. Data disajikan dalam bentuk distribusi frekuensi dan analisisnya.

Hasil: Hasil penelitian menunjukkan terdapat 21 responden yang mengalami prolapsus uteri. Responden terbanyak berusia $61-70$ tahun $(42,8 \%)$, pekerjaan sebagai ibu rumah tangga $(71,4 \%)$, dan paritas lebih dari $4(85,7 \%)$. Keluhan yang paling sering dialami pada saat pertama datang adalah terasa benjolan di jalan lahir $(81,0 \%)$, dengan diagnosis prolapsus uteri derajat 3 $(57,1 \%)$, dan disertai penyakit penyerta $(66,7 \%)$.

Kesimpulan: Prolapsus uteri pada wanita menopause di daerah pesisir ditemukan pada ibu rumah tangga, usia 61-70 tahun, grande multipara, dengan keluhan utama terasa benjolan di jalan lahir disertai penyakit penyerta, dan didiagnosis derajat 3. Perlu dilakukan penyuluhan, konseling dan edukasi mengenai gejala dan penatalaksanaan prolapsus uteri.

Kata kunci: Daerah pesisir, prolaps uteri, wanita menopause.

\section{MENENTUKAN CUT-OFF POINT KENAIKAN BERAT BADAN SELAMA KEHAMILAN UNTUK MEMPREDIKSI BAYI BERAT LAHIR RENDAH PADA BAYI CUKUP BULAN DARI IBU DENGAN INDEKS MASSA TUBUH NORMAL}

Rosinta Pratiwi, Vicky Admiral Aprizano, Risanto Siswosudarmo

Departemen Obstetri dan Ginekologi, Fakultas Kedokteran, Universitas Gadjah Mada/RS Sardjito, Yogyakarta
Tujuan: Untuk menentukan cut-off point kenaikan berat badan selama kehamilan hubungannya dengan bayi berat lahir rendah pada bayi cukup bulan dari ibu dengan indeks masa tubuh normal.

Metode: Merupakan penelitian potong lintang yang dilakukan di Rumah Sakit Sardjito dan 9 rumah sakit afiliasi di Provinsi Jawa Tengah. Penelitian ini memasukkan 619 perempuan yang memenuhi kriteria kelayakan. Digunakan kurva ROC dan chi-square test untuk analisis statistik.

Hasil: Rerata dan deviasi standar index massa tubuh, kenaikan berat badan selama kehamilan, dan berat lahir bayi masing-masing adalah 21,28 $\pm 1,87$ $\mathrm{kg} / \mathrm{m} 2,11,62 \pm 4,33 \mathrm{~kg}$ dan 3041,61 \pm 385,70 gram. Jumlah bayi berat lahir rendah $<2.500$ gram adalah $6 \%$. Kurva ROC menunjukkan bahwa cut-off point kenaikan berat badan selama kehamilan dan kaitannya dengan bayi berat lahir rendah adalah $8,5 \mathrm{~kg}$. Analisis lanjut menunjukkan angka bayi berat lahir rendah sebanyak $21,1 \%$ untuk kenaikan berat badan selama kehamilan < $8,5 \mathrm{~kg}$ dibandingkan dengan $1,3 \%$ untuk kenaikan berat badan selama kehamilan $\geq 8,5 \mathrm{~kg}$. Risiko terjadinya bayi berat lahir rendah pada ibu dengan kenaikan berat badan selama kehamilan $\geq 8,5 \mathrm{~kg}$ lebih tinggi secara signifikan (Resiko Relatif 16,59; 95\% Interval Kepercayaan 7,06-38,98).

Kesimpulan: Cut-off point kenaikan berat badan selama kehamilan untuk menghindari kejadian bayi berat lahir rendah pada banyi cukup bulan pada ibu dengan index massa tubuh normal adalah $8,5 \mathrm{~kg}$. Risiko memiliki bayi berat lahir rendah adalah 16,59 kali lebih besar jika kenaikan berat badan selama kehamilan di bawah $8,5 \mathrm{~kg}$.

Kata kunci: Bayi berat lahir rendah, indeks masa tubuh normal, kenaikan berat badan selama kehamilan.

\section{PENGARUH AKTIVITAS FISIK TERHADAP DENSITAS MASSA TULANG PADA PEREMPUAN USIA REPRODUKTIF DENGAN INDEKS MASSA TUBUH NORMAL}

Pravitasari, Yahya Nurlianto, Phyowai Ganap, Risanto Siswosudarmo

\section{Departmen Obstetri dan Ginekologi, Fakultas Kedokteran, Kesehatan Masyarakat dan Keperawatan, Universitas Gadjah Mada/RS Sardjito Yogyakarta}

Tujuan: Untuk mengetahui pengaruh aktivitas fisik terhadap densitas massa tulang pada perempuan usia reproduktif dengan indeks massa tubuh normal.

Metode: Penelitan ini menggunakan rancangan potong lintang. Sampel diambil dari perempuan angkatan udara Lanud Adisucipto Yogyakarta. Se- 
banyak 40 sampel yang menenuhi kriteria diambil, terdiri atas 23 perempuan yang melakukan aktivitas fisik berat dan 17 aktifitas fisik ringan. Densitas massa tulang diukur dengan metode Dual X-rays Absorptiometry di bagian Radiologi RS Hardjolukito. T-test dan Chi-square test dipakai untuk analisis statistika.

Hasil: Kedua kelompok sebanding dalam umur dan indeks massa tubuh, tetapi tidak dalam kadar E2. Kadar E2 pada kelompok aktivitas fisik ringan lebih tinggi dbanding kelomok aktivitas fisik berat (108,31 \pm $83,24$ vs. $59,06 \pm 48,39 \mathrm{pg} / \mathrm{mL})$. DMT pada mereka yang melakukan aktivitas fisik berat tidak berbeda dengan yang melakukan aktifitas fisik ringan baik secara klinis maupun statistik pada kedua kelompok yakni $0,991 \pm 0,120$ vs. $0,960 \pm 0,097$ ( $\Delta$ means $-0,031$; $95 \%$ CI $-0,1028-0,041 ; \mathrm{p}=0,39)$. Pada penelitian ini tidak terlihat adanya penurunan DMT

Kesimpulan: Penelitian ini menunjukkan aktivitas fisik tidak mempengaruhi DMT pada perempuan usia reproduktif.

Kata kunci: Aktivitas fisik, perempuan usia reproduktif, densitas massa tulang.

\section{KEGAGALAN ANTENATAL CARE DALAM MENDETEKSI PREEKLAMPSIA PADA KASUS EKLAMPSIA: LAPORAN KASUS DARI KETAPANG, KALIMANTAN BARAT}

\author{
Setiawan V, Sugiarto A, Avriyani R, Hidayat F \\ RSUD Agoesdjam, Ketapang, Kalimantan Barat, \\ Indonesia
}

Latar belakang: Preeklampsia dan eklampsia adalah salah satu penyebab utama mortalitas dan morbiditas maternal dan perinatal di seluruh dunia. Insiden preeklampsia di negara berkembang tujuh kali lebih tinggi daripada di negara maju. Hal ini disebabkan rendahnya kualitas dan kuantitas antenatal care dalam upaya deteksi dan penanganan terhadap risiko terjadinya preeklampsia.

Laporan Kasus: Perempuan, 28 tahun, hamil ketiga datang ke rumah sakit dengan kejang tiga kali dan tekanan darah 190/110 mmHg disertai proteinuria (+3) saat usia kehamilan 39 minggu. Keluhan nyeri kepala dan pandangan kabur muncul dua hari sebelumnya namun diabaikan. Pasien hanya kontrol kehamilan sebanyak lima kali hingga usia kehamilan 34 minggu dan tidak ditemukan tekanan darah tinggi serta pemeriksaan protein urine tidak pernah dilakukan. Pasien memiliki riwayat kejang pada kehamilan pertama enam tahun yang lalu. Pemeriksaan ultrasonografi pada usia kehamilan 34 minggu menunjukkan janin tunggal intrauterin, plasenta di posterior, letak kepala, dan taksiran berat janin 2100 gram. Terminasi kehamilan dilakukan dengan seksio sesarea. Lahir bayi perempuan langsung menangis dengan berat 3000 gram dan panjang $46 \mathrm{~cm}$. Pasien dipulangkan pada hari ke-6 dengan kondisi stabil dan tekanan darah normal.

Diskusi: World Health Organization merekomendasikan delapan kali kunjungan antenatal care selama kehamilan dan lima diantaranya pada trimester ketiga, karena 90\% kasus preeklampsia terjadi diatas usia kehamilan 34 minggu. Pada fasilitas kesehatan primer dengan sumber daya terbatas, diharapkan preeklampsia dapat dideteksi dengan identifikasi gejala, pengukuran tekanan darah, protein urine, dan berat badan. Pada fasilitas kesehatan yang lebih tinggi dapat disertai dengan pemeriksaan jumlah trombosit dan serum kreatinin. Diharapkan dengan standar pemeriksaan seperti ini tidak ada kasus preeklampsia yang tidak terdeteksi, terutama pada pasien yang berisiko tinggi.

Kesimpulan: Preeklampsia dapat dideteksi mulai dari fasilitas dengan sumber daya terbatas jika menerapkan antenatal care dengan kualitas dan kuantitas yang baik. Perlu adanya standar pemeriksaan dalam mendeteksi preeklampsia yang mudah diterapkan mulai dari fasilitas kesehatan primer serta edukasi untuk melakukan antenatal care sesuai jadwal.

Kata kunci: Preeklampsia, antenatal care.

\section{PROFIL KASUS PERDARAHAN PASCA PERSALINAN DI RSUD JOMBANG PERIODE BULAN JANUARI-DESEMBER 2016}

Ayu Prima Kusuma Putri,

Rumah Sakit Universitas Muhammadiyah Malang
Email: ayu.endra2012@gmail.com

Latar belakang: Perdarahan post partum adalah perdarahan yang terjadi setelah persalinan melebih 500 cc setelah melahirkan. Di Indonesia, terbukti masih tinggi angka kematian ibu yang disebabkan karena perdarahan post partum (PPP).

Tujuan: untuk mengetahui profil perdarahan pasca persalinan di RSUD Jombang pada periode januari-desember 2016.

Metode: Jenis penelitian ini bersifat deskriptif analitik dengan menggunakan teknik total sampling dimana sampel di ambil dari data rekam medik penderita perdarahan pasca persalinan di RSUD Jombang periode januari-desember 2016. Data-data sampel yang dikumpulkan di analisis dengan uji ChiSquare. 
Hasil: Pada penelitian ini terdapat 73 kasus Perdarahan Pasca Persalinan dari total 2089 (3,5\%) persalinan selama periode januari-desember 2016 dengan usia ibu rata rata 29,05 tahun. Semua kasus perdarahan pasca persalianan melahirkan secara spontan $100 \%$. Sebanyak 93,15\% (68 pasien) kasus adalah rujukan baik dari Bidan praktek swasta, puskesmas, maupun rumah sakit. Pasien yang mengalami Perdarahan pasca persalinan paling banyak pada parietas ke 2 yaitu 45,2\% (33 pasien). Penyebab Perdarahan Pasca persalianan tersering adalah sisa plasenta dan retensio plasenta masing masing 36,99\% dan $34,35 \%$.

Kesimpulan: Pada penelitian ini dapat ditarik kesimpulan bahwa kasus terbanyak perdarahan pasca persalinan di RSID Jombang disebabkan karena jaringan baik sisa maupun tertinggal (retensio) dan banyak di dapatkan dari rujukan.

Saran: Dari penelitian ini disarankan untuk memberikan pelatihan secara berkala kepada petugas kesehatan terutama di faskes tingkat pertana baik dokter umum maupun bidan supaya lebih tahu tentang persalinan sehat dan normal untuk mengurangi angka kematian ibu.

Kata kunci: Profil perdarahan pasca persalinan, RSUD Jombang, periode Januari-Desember 2016.

\section{HUBUNGAN LEUKOSITURIA TERHADAP KEJADIAN KETUBAN PECAH DINI USIA KEHAMILAN KURANG DARI 37 MINGGU DI RUMAH SAKIT UNIVERSITAS MUHAMMADIYAH MALANG PERIODE 2015- 2017}

Ayu Prima Kusuma Putri, Mochamad Ma'roef

\section{Rumah Sakit Universitas Muhammadiyah Malang Email: ayu.endra2012@gmail.com}

Latar belakang: Masalah KPD memerlukan perhatian yang lebih besar, karena prevalensinya yang cukup besar dan cenderung meningkat. Kejadian KPD pada atau lebih dari usia kehamilan 37 minggu (aterm) terjadi pada sekitar 6,45-15,6\% kehamilan cukup bulan (aterm) dan KPD pada usia kehamilan kurang dari 37 minggu terjadi pada sekitar 2-3 persen dari semua kehamilan tunggal dan 7,4\% pada kehamilan kembar.

Tujuan: Tujuan Penelitian ini adalah untuk mengetahui hubungan antara leukosituria terhadap kejadian Ketuban pecah dini usia kehamilan kurang dari 37 minggu di Rumah Sakit Umum Universitas muhammadiyah Malang periode 2015-2017.
Metode: Metode Penelitian ini bersifat analitik observasional, dengan pendekatan secara Crossectional study. Dianalisis dengan Chi Square.

Hasil: Pada penelitian ini terdapat 36 Sampel yang sesuai dengan kriteria inklusi didapatkan 18 pasien dengan KPD usia kehamilan kurang dari 37 minggu dan 18 pasien dengan KPD usia kehamilan lebih dari 37 minggu. KPD banyak terjadi pada ibu yang hamil multigravida sebanyak 58,3\% yaitu 21 pasien. Pasien dengan usia kehamilan 38-39 minggu banyak mengalami ketuban pecah dini. Pada penelitian ini didapatkan sebanyak $18 \mathrm{ibu}$ dengan persalinan preterm terdeteksi, 9 leukosituri positif dan 9 lainnya leukosituri negative. Sementara pada persalinan aterm sebanyak $1 \mathrm{ibu}$ terdeteksi leukosituri positif.

Kesimpulan: Hasil analisis antara kejadian persalinan preterm usia kehamilan kurang dari 36 minggu) dengan leukosituri didapatkan hubungan yang bermakna.

Kata kunci: Leukosituria, ketuban pecah dini usia kehamilan kurang dari 37 minggu.

\section{PROFIL ANGKA KEMATIAN IBU DI KABUPATEN TIMOR TENGAH UTARA, NUSA TENGGARA TIMUR TAHUN 2018}

Scovani L, Kartiningsih A

\section{Rumah Sakit Umum Daerah Kefamenanu, Timor Tengah Utara, Nusa Tenggara Timur}

Latar belakang: Berdasarkan data ASEAN Statistical Report on Millenium Development Goals 2017, Angka Kematian Ibu di Indonesia menempati urutan kedua tertinggi. Tingginya angka kematian ibu terutama terdapat pada beberapa provinsi pada bagian Timur Indonesia yang masih belum mencapai target Rencana Strategis pemerintah. Nusa Tenggara Timur merupakan salah satu provinsi yang belum mencapai target cakupan yang ditentukan oleh pemerintah. Salah satunya Kabupaten Timor Tengah Utara mengalami lonjakan kasus kematian ibu selama tahun 2018. Untuk mengerti dan mencari solusi permasalahan ini diperlukan kerjasama dari berbagai pihak.

Tujuan: Mengembangkan pemahaman mengenai kematian ibu di Kabupaten Timor Tengah Utara.

Metode: Deskriptif kuantitatif dengan populasi masyarakat Kabupaten Timor Tengah Utara. Pengambilan data didapatkan dari dokumentasi pelaporan Kematian Ibu pada Dinas Kesehatan Kabupaten Timor Tengah Utara, laporan rujukan Rumah Sakit Umum Daerah Kefamenanu, Timor Tengah Utara, profil serta data demografis Kabupaten Timor Tengah Utara 
berdasarkan data Dinas Kependudukan Timor Tengah Utara.

Hasil: Pada tahun 2018 dibandingkan dengan tahun 2017, kematian ibu masih disebabkan tiga penyebab utama yaitu perdarahan, preeklampsiaeklampsia, dan infeksi. Walaupun sebanyak $70 \%$ proses persalinan sudah ditolong oleh tenaga kesehatan, namun masih terdapat masalah yaitu $60 \%$ ibu berusia diatas 35 tahun, $80 \%$ kematian ibu mengalami kesulitan akses terhadap fasilitas kesehatan serta lamanya pengambilan keputusan menyebabkan meningkatnya kejadian kematian Ibu. Dinas Kesehatan Timor Tengah Utara telah mengusulkan solusi yaitu Rencana Pembangunan Jangka Menengah Daerah namun masih terdapat kelemahan pada pelaksanaannya.

Kesimpulan: Meningkatnya angka kematian ibu pada Kabupaten Timor Tengah Utara di tahun 2018 tidak hanya disebabkan oleh faktor internal pasien, namun terdapat faktor eksternal yang harus diperhatikan sehingga dapat mencegah terjadinya kematian ibu. Dibandingkan dengan tahun 2017 hanya tercatat satu kematian ibu namun belum disertai dengan pencatatan dan pelaporan kejadian yang lengkap sehingga kenyataannya tidak terwakili dengan baik. Diperlukan kerjasama multidisipliner dan juga peran masyarakat demi mewujudkan turunnya angka kematian ibu.

Kata kunci: Angka kematian ibu, Timor Tengah Utara.

\section{HEALTH POLICY DECISION MAKING IN SAFE MOTHERHOOD REGIONAL ISSUE}

Gulam Gumilar, Sardjana Atmadja

Department of Obstetrics and Gynecology, Faculty of Medicine Islamic State of Syarif Hidayatullah

University, Jakarta

Objectives: To reduce maternal and morbidity in half by the 2017, the safe motherhood initiative was launched.

Methods: Mobilizing political will, involving community members, sharing information, sharing the media and sensitizing men to the issues.

Results: More than 365 /100.000 life birth women die every year because of complications related to pregnancy and child birth. The disparity between maternal death rates in developing and developed countries is greater than for any other common category of death. Poor maternal health during pregnancy is directly linked to poor health in the infant. Therefore, a mother's health and survival continues to be critically important throughout a child's life. Pregnant women and children suffer first and most under poor socioeconomic conditions. The success of safe motherhood initiative depends on the active participation of a wide range of individuals and organizations who can contribute ideas, skills, and funds, because the problem stems not only from inadequate health services, but mostly also from the social, cultural, and economic environment in which women live.

Conclusions: Health policy decision making in safe motherhood at least should be based on the assessment of Maternal Health situation and health services and the assessment of socio-cultural aspects of safe motherhood of each region.

Keywords: Maternal health, infant health and child survival, health policy in safe motherhood.

\section{STRATEGIC AREAS INTERVENTION WITH THEIR RESPECTIVE INDICATORS HAVE BEEN IDENTIFIED THAT MAY BE CONSIDERED KEY DRIVERS REDUCTION OF MATERNAL MORTALITY IN INDONESIA}

Gulam Gumilar, Sardjana Atmadja

\section{Department of Obstetrics and Gynecology Syarif Hidayatullah State Islamic University Jakarta}

Objectives: The main objective is to assess the progress made in reducing maternal morbidity and mortality in Indonesia and to help to implement the corrective measures needed at implement the corrective measures needed at different stages. This requires strengthening of the on- going monitoring system.

Material and Method: Data will be verified using sources such as an Operational Research System Analysis (ORSA) and was carried out in governmentowned type $\mathrm{C}$ hospitals in Indonesia. The main variables observed were a) working ethos b) blood facilities c) communication facilities. Three strategic areas to accurate the reduction of maternal mortality, interventions with their respective indicators have been indentified and prioritized.

Results: There are 3 determinants factors that may be considered key drivers in the reduction of maternal mortality, there are also specific potential measures directly aimed at reducing maternal mortality that can be adopted in the health sector. The contribution of working ethos variable is $36,8 \%$, the contribution of blood facilities is $36,7 \%$ and the contribution of communication facilities is $26,3 \%$ in Clinical Management model in order to reduce maternal mortality in government-owned type $\mathrm{C}$ hospitals.

Conclusion: Based on the official data provided by Minister of Health Indonesia, the region's maternal 
mortality rates decreased $35 \%$ in late 2015 . Approximately $90 \%$ of maternal mortality could be prevented using knowledge already available in this country.

Keywords: working ethos variable, the contribution of blood facilities is 36 , the contribution of communication facilities, Clinical Management model.

\section{PENILAIAN KUALITAS HIDUP PASIEN KANKER SERVIKS DENGAN KEMOTERAPI PAKLITAKSEL-KARBOPLATIN DI RSUD DR. SAIFUL ANWAR}

I Wayan Subage, Edy Mustofa, Yahya Irwanto

\section{Pendidikan Dokter Spesialis Obstetri dan Ginekologi, FK Universitas Brawijaya}

Latar belakang: Kanker serviks merupakan jenis kanker yang menempati urutan kedua setelah kanker payudara yang menyerang kaum perempuan. Tipe sel kanker yang terbanyak adalah tipe sel skuamosa dengan stadium yang paling banyak terdiagnosis adalah IIBIIIB. Penatalaksanaan pada pasien kanker serviks stadium lanjut (stadium IIB-IIIB) yang non-operabel yaitu dengan pemberian kemoterapi. Menurut panduan praktek klinis RSUD dr Saiful Anwar, kemoterapi yang dapat diberikan pada pasien kanker serviks stadium IIBIIIB salah satunya adalah regimen PaklitakselKarboplatin yang memliki efektivitas tinggi namun efek samping yang ditimbulkan juga cukup tinggi.

Tujuan: Untuk mengetahui kualitas hidup pasien kanker serviks yang diberi terapi kombinasi PaklitakselKarboplatin di RSUD dr Saiful Anwar.

Metode: Penelitian kualitas hidup pasien yang diberikan kemoterapi regimen Paklitaksel-Karboplatin dilakukan secara observasional dengan rancangan case study. Populasi penelitian adalah pasien yang menderita penyakit kanker serviks stadium IIB-IIIB tipe sel skuamosa dan baru pertama kali menjalani kemoterapi Paklitaksel-Karboplatin, dengan jumlah sampel sebanyak 22 pasien dengan metode consecutive sampling. Pengumpulan data dilakukan dengan menggunakan kuesioner EORTC QLQ C30.Uji normalitas data dilakukan dengan menggunakan Uji Shapiro-Wilk. Data yang memiliki distribusi normal seperti domain fungsi fisik dianalisis menggunakan Paired T test. Data yang berdistribusi tidak normal ditranformasi dengan mengunakan fungsi log. Data hasil transformasi yang tidak berdistribusi normal dianalisis menggunakan Uji Wilcoxon.

Hasil: Terdapat perbedaan bermakna pada nilai kualitas hidup sebelum dan setelah diberikan kemoterapi regimen Paklitaksel-Karboplatin $(\mathrm{p}<0,05)$.
Kemoterapi Paklitaksel-Karboplatin dapat meningkatkan kualitas hidup pasien kanker serviks terlihat dengan adanya penurunan nilai mean yaitu dari 5,36 menjadi 9,73 ( $\mathrm{p}<0,001)$.

Kesimpulan: Kualitas hidup pasien kanker serviks stadium IIB-IIIB sel skuamosa yang diberikan kemoterapi regimen Paklitaksel-Karboplatin di RSUD dr. Saiful Anwar Malang akan mengalami peningkatan kualitas hidup. serviks

Keywords: Kualitas hidup, kemoterapi, kanker

\section{EFEKTIFITAS KEGEL EXERCISE UNTUK PENCEGAHAN POSTPARTUM FEMALE SEXUAL DYSFUNCTION DALAM UPAYA PENINGKATAN KUALITAS KELUARGA}

Catharina Galuh Suryondari, Eka Yuni Indah Nurmala, Dewa Gede Setya Budhidharma, Edy Mustofa, Mulyohadi Sungkono

Pendidikan Dokter Spesialis Obstetri dan Ginekologi, Fakultas Kedokteran Universitas Brawijaya - RSUD dr Saiful Anwar Malang

Latar belakang: Kelahiran merupakan suatu peristiwa yang meningkatkan rasa stres pada sebagian besar perempuan dan dapat meningkatkan kejadian disfungsi seksual pada perempuan tersebut. Kenyataannya kepuasan seksual yang menunjang kestabilan mental perempuan sering dilupakan. Kehamilan dan persalinan menyebabkan perubahan mekanik dan denervasi otot-otot dasar panggul yang menimbulkan keluhan stres inkotinensia, prolaps organ panggul dan gangguan seksual sehingga menurunkan kualitas hidup pasien. Latihan otot dasar panggul atau Kegel exercise yang dapat menguatkan otot dasar panggul. Latihan ini berhubungan dengan berbagai perubahan yang terjadi pada kekuatan otot dasar panggul seperti sphincter uretra dan sphincter anal.

Tujuan: Penelitian ini bertujuan untuk menganalisis bagaimana pelaksanaan Kegel exercise untuk mencegah disfungsi seksual pada ibu postpartum sehingga akan meningkatkan kualitas hidup ibu dalam keluarga yang harmonis.

Metode: Penelitian ini merupakan penelitian komparatif dengan pendekatan case control dengan perbandingan responden 1:1 dengan jumlah masingmasing 20 responden.

Hasil: Hasil penelitian menunjukkan perlakuan kegel exercise akan menurunkan kejadian disfungsi seksual $(\mathrm{p}=0,034)$.

Kesimpulan: Kegel exercise akan menurunkan kejadian disfungsi seksual pada wanita postpartum 
sehingga diharapkan akan dapat meningkatkan kualitas keluarga yang harmonis.

Kata kunci: Kegel exercise, disfungsi seksual.

\section{STUDI EPIDEMIOLOGI: RUJUKAN TERLAMBAT PADA KELAINAN SPEKTRUM PLASENTA AKRETA PADA PUSAT RUJUKAN TERSIER PLACENTA AKRETA TAHUN 2014- 2018}

Diana Apriliyana Nur ${ }^{1}$, Rizki Pranadyan², Rozi Aditya ${ }^{2}$

${ }^{I}$ PPDS-I Departemen/SMF Obstetri dan Ginekologi RSUD dr. Soetomo, Fakultas Kedokteran Universitas Airlangga Surabaya, ${ }^{2}$ Staf Pengajar Departemen/SMF Obstetri dan Ginekologi RSUD dr. Soetomo, Fakultas Kedokteran Universitas Airlangga Surabaya

Latar belakang: Kehamilan dengan kelainan spektrum plasenta akreta merupakan masalah obstetrik yang jumlahnya semakin meningkat setiap tahun. Kasus ini memerlukan penanganan secara tepat, cepat dan multidisiplin. Patogenesis yang belum jelas, belum adanya modalitas diagnostik yang pasti, serta belum adanya konsensus nasional mengenai kasus ini menyebabkan angka rujukan terlambat yang menimbulkan morbiditas dan resiko mortalitas masih cukup tinggi.

Tujuan: Mengetahui karakteristik dan luaran maternal kasus rujukan terlambat kelainan spektrum plasenta akreta di RSUD dr. Soetomo Surabaya tahun 2014- 2018.

Metode: Penelitian retrospektif dengan data sekunder dari rekam medis (RM) di RSUD Dr. Soetomo Surabaya tahun 2014-2018

Hasil: Kasus kelainan spektrum plasenta akreta pada periode Januari 2014- Desember 2018 sebanyak 163 kasus, sebanyak 123 kasus merupakan rujukan tepat waktu sedangkan 40 kasus merupakan rujukan terlambat. Dari 40 kasus rujukan terlambat, sebanyak $37,5 \%$ merupakan rujukan post partum. Berdasarkan faktor resiko didapatkan $84 \%$ memiliki riwayat SC, $4 \%$ dengan riwayat kuret dan $12 \%$ dengan riwayat SC disertai kuretase. Pada kasus rujukan post partum, tujuh kasus dirujuk karena didapatkan perdarahan post SC dan dua kasus dirujuk dengan plasenta insitu, lima kasus internal bleeding setelah caesarean histerektomi. Hampir semua kasus rujukan post partum dilakukan operasi ulang dengan jumlah perdarahan durante operasi yang lebih banyak daripada sebelumnya. Didapatkan 5 kasus kematian maternal yang disebabkan oleh syok hipovelemik irreversible. Berdasarkan asal rujukan, pasien yang dirujuk dalam kondisi hamil $44 \%$ berasal dari kota Surabaya, sedangkan pasien yang dirujuk post partum 33,33\% berasal dari rujukan kota Surabaya. Berdasarkan jenis rujukan, kasus rujukan terlambat dalam kehamilan sebanyak 60\% kasus merupakan rujukan gawat darurat dan pada kasus yang rujukan post partum sebanyak $93,3 \%$ merupakan rujukan gawat darurat.

Kesimpulan: Kasus rujukan terlambat kelainan spektrum plasenta akreta di RSUD dr. Soetomo Surabaya masih didapatkan jumlah yang tinggi. Sosialisasi dan pelatihan mengenai managemen kelainan spektrum plasenta akreta masih dibutuhkan.

Kata kunci: Akreta, rujukan terlambat.

\section{HUBUNGAN ANTARA SKIN PREPARATION DENGAN INFEKSI LUKA OPERASI POST SECTIO CAESAREA DI RS ACHMAD MOCHTAR BUKITTINGGI}

Calvindra Leenesa, Roza Sriyanti

Bagian/SMF Obstetri dan Ginekologi Fakultas Kedokteran Universitas Andalas, RSUP Dr. M. Djamil Padang

Latar belakang: Infeksi luka operasi merupakan masalah yang sering ditemukan saat ini dalam tindakan pembedahan. Departemen Kesehatan RI melaporkan sebanyak $55,1 \%$ infeksi luka operasi ditemukan di rumah sakit pemerintah. Hal tersebut sejalan dengan sectio caesarea rate di Indonesia yang tercatat sebesar $6 \%$, berdasarkan data dari WHO (World Health Organization). Skin preparation dapat digunakan untuk mencegah infeksi luka operasi, dengan cara mengurangi jumlah kuman pada kulit sebelum dilakukan insisi.

Tujuan: Untuk melihat hubungan antara skin preparation dengan infeksi luka operasi post sectio caesarea di RS Achmad Mochtar Bukittinggi.

Metode: Penelitian yang dilakukan bersifat analitik mengunakan desain cross sectional study dengan melihat rekam medis subjek sesuai waktu dan tempat penelitian. Sampel adalah seluruh rekam medis ibu melahirkan secara sectio caesarea di Bagian Obstetri dan Ginekologi RS Achmad Mochtar Bukittinggi pada periode 1 Januari 2017 sampai 31 Desember 2017. Sampel diambil dari populasi yang memenuhi kriteria inklusi dan eksklusi. Pengambilan sampel mengunakan teknik simple random sampling yang diambil dari rekam medis RS Achmad Mochtar Bukittinggi. Analisis statistik untuk menilai kemaknaan menggunakan uji chisquare.

Hasil: Pada kelompok sectio caesarea yang tidak dilakukan skin preparation memiliki jumlah responden tertinggi sebesar $59,8 \%$, dengan jumlah responden yang mengalami infeksi luka operasi post sectio caesarea 
sebesar 70,7\%, dengan menyingkirkan semua faktor pemberat, yaitu obesitas, penyulit persalinan dan penyakit penyulit.

Kesimpulan: Terdapat hubungan antara skin preparation dengan infeksi luka operasi post sectio caesarea yang bermakna $(\mathrm{p}<0,021)$ di RS Achmad Mochtar Bukittinggi.

Kata kunci: Sectio caesarea, skin preparation dan infeksi luka operasi.

\section{ONKOLOGI GINEKOLOGI}

\section{KASUS LANGKA MOLA INVASIF SETELAH KEHAMILAN CUKUP BULAN, TERDIAGNOSIS DENGAN ULTRASONOGRAFI: SEBUAH LAPORAN KASUS DAN STUDI LITERATUR}

\author{
Agung Sari Wijayanti, Heru Priyanto
}

\section{Fakultas Kedokteran UNS, Rumah Sakit dr. Moewardi, Surakarta}

Latar belakang: Mola invasif dapat timbul dari berbagai peristiwa kehamilan meskipun dalam kebanyakan kasus didiagnosis setelah kehamilan mola. Mola invasif yang timbul dari kehamilan cukup bulan sebelumnya merupakan kasus yang jarang.

Tujuan: Mendemonstrasikan peran ultrasonografi dalam mendiagnosis mola invasif dan menjelaskan mengenai tatalaksana mola invasif pada kasus ini

Laporan kasus: Wanita 52 tahun P4A0 datang ke Rumah Sakit dr. Moewardi, Surakarta dengan perdarahan dari jalan lahir, nyeri perut tidak khas, gangguan gastrointestinal dan diagnosis awal mola hidatidosa dimana didapatkan gambaran sonografi honey-comb appearance. Pasien tidak aktif secara seksual dengan riwayat kehamilan sebelumnya adalah kehamilan cukup bulan, 16 tahun yang lalu. Hasil pemeriksaan $\beta$-hCG $19.333 \mathrm{IU} / \mathrm{ml}$ dengan ultrasonografi dari divisi ginekologi onkologi menunjukan adanya lesi ireguler hipoekoik sebagian hiperekoik menginvasi miometrium dan hipervaskuler (color score 4) dengan gambaran end-lake pattern. Didapatkan diskontinuitas pada miometrium dan perimetrium dengan gambaran hipoekoik di cavum douglasi, sesuai gambaran perforasi. Pasien menjalani histerektomi atas indikasi perforasi. Hasil patologi anatomi menunjukan gambaran mola invasif.

Hasil: Perkembangan jaringan mola invasif dapat menembus miometrium, menyebabkan perforasi uterus. Ultrasonografi berperan penting dalam menegakan diagnosis mola invasif. Secara sonografis, penyakit trofoblas ganas bermanifestasi hiperekoik, dengan massa padat dan gambaran massa kistik hipervaskular. Kemoterapi merupakan terapi umum pada mola invasif, sedangkan histerektomi diindikasikan jika terdapat perforasi uterus. Pada penyakit trofoblas ganas usia tua dan tidak membutuhkan reproduksi kembali, histerektomi dianggap menurunkan mortalitas-morbiditas dan menurunkan kebutuhan siklus kemoterapi. Pasien menjalani kemoterapi EMA siklus 1 dan pemantauan $\beta$ hCG.

Kesimpulan: Kasus mola invasif yang berasal dari kehamilan cukup bulan merupakan kasus yang langka. Peran ultrasonografi dalam mendiagnosis mola invasif dengan tepat dapat menurunkan morbiditas dan mencegah kesalahan terapi. Kemoterapi merupakan terapi umum dan histerektomi dilakukan jika terdapat indikasi.

Kata kunci: mola invasif, color doppler ultrasound, histerektomi

\section{HUBUNGAN TIPE HISTOPATOLOGI DENGAN RESPON KEMOTERAPI NEOADJUVANT PADA KANKER SERVIKS STADIUM IB2 DAN IIA2}

\section{Gistin Husnul Khatimah}

Bagian/SMF Obstetri dan Ginekologi, Fakultas Kedokteran Universitas Andalas. RSUP Dr. M. Djamil Padang

Latar belakang: Kanker serviks menempati urutan keempat di seluruh dunia dan urutan kedua di Indonesia yang paling umum terjadi pada wanita. Kemoterapi telah dievaluasi sebagai salah satu strategi pengobatan kanker serviks stadium IB2 dan IIA2. Namun penggunaan kemoterapi neoadjuvant masih kontroversi, pada pasien yang resisten dengan kemoterapi akan menunda pemberian terapi definitif, sehingga sangat penting untuk menemukan penanda yang dapat mengidentifikasi pasien mana yang relatif lebih resisten terhadap kemoterapi. Tipe squamous cell carcinoma (SCC) diketahui memiliki respon kemoterapi neoadjuvant yang lebih baik dibandingkan dengan nonsquamous cell carcinoma (NSCC) namun belum ada penelitian yang dilakukan di RSUP M Djamil Padang mengenai hal ini sebelumnya.

Tujuan: Untuk melihat Hubungan Tipe Histopatologi Dengan Respon Kemoterapi Neoadjuvant Pada Kanker Serviks Stadium IB2 Dan IIA2.

Metode: Penelitian ini merupakan studi analitik cohort yang dilakukan di RSUP Dr. M. Djamil Padang pada 35 sampel pasien kanker serviks stadium IB2 dan IIA2 yang diberikan kemoterapi neoadjuvant. Pengambilan sampel dilakukan dengan teknik consecutive 
sampling. Data meliputi hasil gambaran histopatologi serta hasil pemeriksaan ultrasonografi sebelum dan sesudah diberikan kemoterapi neoadjuvant. Analisis data mengunakan uji Chi-Square.

Hasil: $C R+P R$ pada kelompok $S C C$ adalah sebesar $32 \%$ dan NSCC adalah 50\%, sedangkan $S D+P D$ adalah sebesar $68 \%$ pada kelompok SCC dan $50 \%$ pada kelompok NSCC.

Kesimpulan: Tidak terdapat hubungan yang bermakna antara tipe histopatologi dengan respon kemoterapi neoadjuvant pada kanker serviks stadium IB2 dan IIA2 $(\mathrm{p}=0.44)$.

Kata kunci: histopatolgi, kemoterapi, kanker serviks

\section{HUBUNGAN PEMAKAIAN AKSEPTOR DEPOT MEDROXYPROGESTERONE ACETATE (DMPA) SELAMA 12 BULAN DENGAN FAKTOR KOAGULASI}

Mega Sari Dewi, Anisya Friska Sari Hasibuan, Delfi Lutan, Elida R Sidabutar, Letta S Lintang, Hanudse Hartono, Rhiza Z Tala

\section{Departemen Obstetri dan Ginekologi Fakultas} Kedokteran Universitas Sumatera Utara Medan

Latar Belakang: Sebagai salah satu program Safe Motherhood Initiative, program Keluarga Berencana diharapkan mampu menurunkan angka fertilitas di Indonesia. Kontrasepsi suntik yaitu DMPA, diyakini memiliki tingkat kegagalan $<0,5 \%$. Namun, salah satu efek DMPA yaitu perdarahan yang tidak teratur akibat gangguan faktor koagulasi.

Tujuan: Menilai hubungan pemakaian (DMPA) selama 12 bulan dengan faktor koagulasi.

Metode: Penelitian ini merupakan penelitian analitik dengan rancangan potong lintang yang dilakukan di Puskesmas Medan Johor pada bulan Juli 2017. Subjek penelitian berjumlah 40 wanita pengguna DMPA selama 12-16 bulan dipilih dengan metode consecutive sampling. Data dianalisis menggunakan uji T-berpasangan.

Hasil: Karakteristik subjek penelitian paling banyak dijumpai adalah kelompok usia 30-39 tahun $(72,5 \%)$, multipara $(82,5 \%)$, memiliki indeks massa tubuh overweight $(37,5 \%)$ serta memiliki siklus dan lama menstruasi tidak normal $(72,5 \%)$. Rerata nilai PT, TT dan APTT berturut-turut sebesar 13,19 $\pm 0,64$ detik, $17,17 \pm 1,28$ detik dan $0,65 \pm 4,19$ detik, serta tidak dijumpai adanya hubungan bermakna antara pemakaian DMPA selama 12 bulan dengan faktor koagulasi $(\mathrm{p}=0,948)$.
Kesimpulan: Tidak terdapat hubungan bermakna antara pemakaian DMPA selama 12 bulan dengan faktor koagulasi $(\mathrm{p}>0,05)$.

Kata kunci: Depot Medroxyprogesterone Acetate, perdarahan, faktor koagulasi

\section{KESESUAIAN HASIL TEMUAN IVA DOKUMENTASI "DOVIA" TERHADAP HASIL TEMUAN KOLPOSKOPI SEBAGAI METODE SKRINING KANKER SERVIKS}

Renny S. Wardany, Laila Nuranna

Departemen Obstetri dan Ginekologi, Fakultas Kedokteran Universitas Indonesia Rumah Sakit Cipto Mangunkusumo, Jl. Salemba Raya No.6, 10430 Indonesia

Latar belakang: Kanker serviks merupakan kanker dengan jumlah kasus baru terbanyak urutan kedua di Indonesia (Globocan 2018). Penyebab kanker serviks telah diketahui yaitu Infeksi Human Papilloma Virus (HPV) sehingga telah diketahui perjalanan penyakitnya maupun metode deteksi dininya. Inspeksi visual dengan asam asetat (IVA) merupakan salah satu metode deteksi dini yang dipilih menjadi program nasional di Indonesia. Namun kurang efektifnya pelaksanaan program penapisan kanker serviks ini masih menjadi masalah di Indonesia. Berkembangnya teknologi untuk mengambil gambaran foto serviks menggunakan perangkat telepon seluler menjadi suatu gagasan metode penapisan alternatif berupa dokumentasi hasil temuan IVA "DoVIA" yang dapat disebut sebagai mini colposcopy.

Tujuan: Untuk mengetahui hasil kesesuaian temuan dokumentasi IVA (Documentation of Visual Inspection with Acetic Acid / DoVIA) terhadap hasil temuan kolposkopi sebagai standar baku skrining kanker serviks.

Metode: Penelitian ini merupakan penelitian deskriptif, menggunakan desain potong lintang yang dilaksanakan pada Maret tahun 2017 - April 2019 dengan mengikutsertakan 71 sampel foto dokumentasi yang diambil oleh peneliti yaitu peserta program pendidikan dokter spesialis (PPDS) Program Studi Obstetri dan Ginekologi Universitas Indonesia.

Hasil: Penelitian ini mengolah 71 dokumentasi serviks menggunakan DoVIA dan kolposkopi, sebelum dan sesudah dilakukan IVA. Kategori penilaian yang dilakukan pada kedua gambar adalah ketajaman gambar, kualitas foto dokumentasi serviks berupa kejelasan tampilan sambungan skuamo kolumnar (SSK), dan kejelasan tampilan epitel putih pada serviks. Hasil yang didapatkan berdasarkan kategori tersebut 
untuk DoVIA terhadap kolposkopi dengan penilaian baik yaitu 55\% : 6\%, 34\% : 7\%, dan 18\% : 4\%. Pada hasil uji kesesuaian hasil gambar DoVIA sama baik dengan kolposkopi $12.7 \%$, kriteria lebih baik dibanding kolposkopi sebesar $85,9 \%$. Hasil IVA positif pada DoVIA $21 \%$, sedangkan pada kolposkopi $18 \%$. Total skoring penilaian DoVIA 496 lebih baik dibanding skoring kolposkopi 348.

Kesimpulan: Hasil kesesuaian kualitas dokumentasi DoVIA terhadap kolposkopi adalah 12,7\% sedangkan $85,9 \%$ hasil DoVIA lebih baik dibandingkan kolposkopi.

Kata kunci: Skrining kanker serviks, DoVIA, kolposkopi.

\section{ACTINOMYCIN-D MEMILIKI RESPON LEBIH BAIK DIBANDINGKAN METHOTREXATE UNTUK NEOPLASIA TROPOBLASTIK GESTASIONAL RISIKO RENDAH: SEBUAH LAPORAN KASUS BERBASIS BUKTI}

Heru Prasetyo ${ }^{1}$, Tofan Widya Utami ${ }^{2}$

${ }^{I}$ Departemen Obstetri dan Ginekologi, Fakultas Kedokteran Universitas Indonesia - RSUPN Dr Cipto Mangunkusumo, ${ }^{2}$ Divisi Ginekologi Onkologi, Departemen Obstetri dan Ginekologi, Fakultas Kedokteran Universitas Indonesia - RSUPN Dr Cipto Mangunkusumo

Latar belakang: Insidensi penyakit tropoblas gestasional (GTD) bervariasi di seluruh dunia. Indonesia memiliki angka GTD yang tinggi, sekitar 10 per 1000 kehamilan. Berdasarkan sistem penilaian FIGO/WHO, GTN risiko rendah (LRGTN) didefinisikan sebagai FIGO stadium I-III dan skor WHO enam atau lebih rendah. Regimen terbaik untuk pasien dengan LRGTN masih diperdebatkan.

Tujuan: Untuk membandingkan efektivitas MTX dan Act-D terhadap LRGTN.

Metode: Pencarian melalui di PubMed dan Cochrane untuk artikel yang relevan. Pencarian terakhir pada 27 Oktober 2018. Daftar referensi dari seluruh penelitian yang memenuhi kriteria kelayakan dan tinjauan kritis juga dilakukan untuk artikel lain yang relevan namun terlewat pada pencarian awal.

Hasil: Pada kelompok MTX, 68.8 \% (MTX 8 hari) dan $59.5 \%$ (MTX mingguan) respon terhadap terapi, untuk kelompok Act-D 83.3\% (pemberian Act-D pulsatil 2 minggu) dan 80\% (Act-D 5 hari) respon terhadap terapi. Pemberian Act-D IV pulsatile lebih baik dibandingkan dengan pemberian MTX pada kondisi respon komplit (OR, 4.86; 95\% CI,1.83-12.90). Regimen IV Act-D 5 hari berhubungan dengan respon yang lebih baik dibandingkan dengan regimen MTX-FA (OR, 12.49; 95\% CI, 2.87-54.34; P < 0.01). Biaya ActD pulsatil sebesar $\$ 4,000$ (rata-rata jumlah siklus: 4 ), MTX mingguan sebesar \$155 (8 siklus), dan MTX 5 hari sebesar \$454 (3 siklus).

Kesimpulan: Hasil dari penelitian saat ini menunjukan bahwa Act- D memiliki respon yhang lebih baik dibanding MTX pada pasien LRTGN, MTX memiliki biaya rata-rata lebih rendah dibanding Act-D dan tidak terdapat perbedaan efek samping pada Act-D dan MTX.

Kata kunci: Neoplasia Tropoblas Gestasional Risiko Rendah (LRGTN), MTX, Act-D.

\section{HUBUNGAN EKSPRESI TOLL LIKE RECEPTORS 4 (TLR 4) DAN HYPOXIA INDUCIBLE FACTOR 1 PADA LESI PRAKANKER SERVIKS DAN KANKER SERVIKS STADIUM IB - IIA}

\section{Gustaf Irianto, Maringan, Siti Salima}

\section{Departemen Obstetri Ginekologi FK Universitas Padjajaran}

Latar belakang: Peranan imunitas didapatkan dalam proses terjadinya kanker. Penanda untuk imunitas Toll-like receptor 4 merupakan peran kunci dalam respon imun terhadap infeksi yang merupakan salah satu sistem kekebalan bawaan yang akan diekspresikan pada kanker serviks dan lesi prakanker. Penilaian progresivitas serta prognosis pasien kanker serviks dikaitkan dengan kadar ekspresi dari TLR 4 tersebut. Adanya perbedaan antara beberapa hasil penelitian mengenai ekspresi TLR 4 yang didapat pada lesi prakanker dan kanker serviks merupakan salah satu alasan penelitian ini dibuat. Penelitian ini juga menghubungkan pada biomarker molekuler dari hipoksia yakni Hypoxia-Inducible Factor $1 \alpha$. Pada lesi prakanker serviks dan kanker serviks stadium IB-IIA ditemukan adanya peningkatan biomarker molekuler jaringan yaitu HIF-1 $\alpha$. Pada penelitian ini akan dilihat hubungan reseptor TLR 4 serta HIF-1 $\alpha$ yang nantinya dapat digunakan sebagai landasan teori untuk target terapi pada kanker serviks.

Metode: Penelitian ini adalah penelitian observasional analitik dengan rancangan cross-sectional. Subjek penelitian adalah parafin blok pasien lesi prakanker serviks dan kanker serviks stadium IB - IIA di bagian Obstetri dan Ginekologi, Rumah Sakit Dr. Hasan Sadikin Bandung yang telah menjalani pengobatan. Parafin blok pasien yang diikutsertakan adalah pasien yang memenuhi kriteria inklusi $(n=40)$ Hasil: Pada penelitian diperoleh perbedaan yang 
signifikan antara ekspresi TLR 4 pada kanker serviks dan lesi prakanker (P0.05). Keterkaitan antara ekspresi TLR 4 dengan ekspresi HIF-1 $\alpha$ pada kanker serviks dan lesi prakanker dengan menggunakan analisis statistik Spearman menunjukan bahwa tidak adanya korelasi yang signifikan $(\mathrm{P}>0.05)$.

Kesimpulan: Pada penelitian ini menyimpulkan bahwa ekspresi TLR 4 pada kanker serviks stadium IBIIA lebih tinggi dibandingkan lesi prakanker serviks. Sedangkan ekspresi HIF-1 $\alpha$ pada kanker serviks stadium IB-IIA dibandingkan lesi prakanker serviks tidak ditemukan perbedaan. Ekspresi TLR 4 dan HIF-1 $\alpha$ pada kanker serviks dan prakanker serviks tidak ditemukan korelasi diantara keduanya.

Kata kunci: Karsinoma serviks, toll-like receptor 4, hypoxia-inducible.

\section{PERANAN BACILLE CALMETTE-GUERIN (BCG) TERHADAP LESI PRAKANKER SERVIKS DERAJAT RENDAH}

Tendi Robby Setia, Yudi Mulyana Hidayat, Putut Giri Saputro

\section{Departemen Obstetri Ginekologi FK Universitas Padjajaran/ RS Hasan Sadikin}

Latar belakang: Lesi prakanker serviks merupakan awal dari perubahan menuju kanker serviks. Banyak teori mengenai lesi prakanker yang dapat berkembang menjadi keganasan. Terdapat bukti ilmiah mengenai peran sistem imun dalam perkembangan dan progresivitas lesi prakanker serta vaksin BCG yang berperan dalam modulasi sistem imun. Vaksin BCG dapat digunakan sebagai vaksin terapi kanker dengan dasar BCG dapat mendorong reaksi imun terhadap antigen vaksin.

Metode: Penelitian ini merupakan penelitian eksperimental dengan rancangan pretest- posttest with control design di Poliklinik Rumah Sakit Dr. Hasan Sadikin Bandung pada bulan Desember 2017-Desember 2018. Populasi target adalah pasien dengan hasil pemeriksaan inspeksi visual asam asetat 3-5\% (IVA) positif yang kemudian dilakukan kolposkopi dan dilanjutkan biopsi terarah dengan hasil biopsi cervical intraepithelial neoplasia (CIN) 1. Pasien dengan hasil biopsi CIN 1 secara acak diberikan suntikan BCG atau suntikan plasebo yang kemudian akan dilakukan observasi selama 1 tahun dan dilakukan pemeriksaan IVA kembali. Subjek penelitian yang memenuhi kriteria inklusi adalah 18 pasien, terdiri dari 9 sampel yang diberikan suntikan vaksin BCG (kelompok perlakuan) dan 9 sampel yang diberikan suntikan plasebo (kelompok kontrol).
Hasil: Untuk pemeriksaan IVA bulan ke-0 pada kelompok BCG kategori positif sebanyak 9 (100.0\%) sedangkan untuk pemeriksaan IVA bulan ke-12 pada kelompok BCG kategori positif sebanyak 3 (33.3\%) dan negatif menjadi sebanyak $6(66.7 \%)$. Hasil uji statistik pada kelompok perlakuan diperoleh informasi nilai $\mathrm{p}$ $<0.05$.

Kesimpulan: Terdapat peranan pemberian vaksin BCG) terhadap lesi prakanker serviks derajat rendah.

Kata kunci: Vaksin BCG, pemeriksaan IVA, lesi prakanker serviks.

\section{GAMBARAN CAKUPAN PEMERIKSAAN INSPEKSI VISUAL DENGAN ASAM ASETAT (IVA) OLEH TENAGA KESEHATAN TERLATIH DI WILAYAH ENDE TAHUN 2016 - 2018}

Nessyah Fatahan ${ }^{1}$, Kartiwa Hadi Nuryanto ${ }^{2}$, Laila Nuranna $^{2}$, Lidya F. Nembo ${ }^{3}$, Fransisca N. Ero ${ }^{3}$

${ }^{\text {I}}$ Female Cancer Program Jakarta, Fakultas Kedokteran Universitas Indonesia, Rumah Sakit Cipto

Mangunkusumo, ${ }^{2}$ Departemen Obstetri dan Ginekologi, Fakultas Kedokteran Universitas Indonesia Rumah Sakit Cipto Mangunkusumo, ${ }^{3}$ Female Cancer Program Ende, Nusa Tenggara Timur, Indonesia

Latar belakang: Data Globocan tentang jumlah kasus baru kanker serviks di Indonesia tahun 2018 yaitu urutan kedua setelah kanker payudara. Hal ini sangatlah memprihatinkan dikarenakan kanker serviks merupakan penyakit yang dapat dicegah dengan deteksi dini. Inspeksi Visual dengan Asam Asetat (IVA) merupakan pilihan deteksi dini kanker serviks yang memadai untuk di Indonesia namun membutuhkan tenaga kesehatan terlatih yang mampu menginterpretasi hasil pemeriksaannya. Sejak tahun 2005, pelatihan deteksi dini kanker serviks telah dilakukan di Indonesia. Salah satu penyelenggaranya adalah Female Cancer Program (FCP) yang berkolaborasi dengan dinas kesehatan setempat. Ende merupakan salah satu wilayah di Timur Indonesia yang telah melaksanakan program ini sejak tahun 2015. Namun hingga saat ini belum ada tulisan yang menghubungkan antara cakupan pemeriksaan IVA dibanding jumlah tenaga kesehatan terlatih di wilayah tersebut.

Tujuan: Untuk mengetahui cakupan pemeriksaan inspeksi visual dengan asam asetat (IVA) dibandingkan dengan jumlah tenaga kesehatan terlatih di wilayah Ende.

Metode: Penelitian deskriptif retrospektif tahun 2016 - 2018 pada data yang terkumpul oleh FCP dan Dinas Kesehatan kota Ende. 
Hasil: Program deteksi dini kanker serviks dengan metode inspeksi visual dengan asam asetat (IVA) telah berjalan di hampir seluruh puskesmas di Kabupaten Ende (92\%). Hal ini dikarenakan, puskesmas tersebut telah memiliki tenaga kesehatan terlatih untuk pemeriksaan IVA. Total cakupan pemeriksaan IVA selama tahun 2016 - 2018 sebanyak 5301 orang. Angka cakupan ini meningkat pertahunnya yaitu sebanyak 54\% dan 124\% (berturut-turut dari tahun 2016-2018). Peningkatan cakupan ini seiring dengan peningkatan jumlah tenaga kesehatan terlatih di wilayah tersebut dengan total tenaga kesehatan terlatih sebanyak 96 orang pada tahun 2018. Rerata tenaga kesehatan terlatih di masing-masing puskesmas adalah 3 orang, dengan jumlah paling sedikit yaitu 1 orang dan paling banyak adalah 10 orang. Persentase cakupan pemeriksaan IVA tertinggi di tahun 2018 adalah Puskesmas Wolowaru yaitu sebesar $17.5 \%$ atau sebanyak 521 orang (dengan rasio pemeriksa dan cakupannya sebesar 1: 174), sedangkan persentase cakupan pemeriksaan IVA tahun 2018 di Puskesmas Rukun Lima (sebagai puskesmas dengan tenaga kesehatan terlatih terbanyak) adalah 2.9 $\%$, atau sebanyak 120 orang (dengan rasio pemeriksa dan cakupannya sebesar 1:12). Persentase cakupan pemeriksaan terendah adalah Puskesmas Roga yaitu sebesar $0.5 \%$, atau sebanyak 5 orang (dengan rasio pemeriksa dan cakupannya sebesar 1:3).

Kesimpulan: Cakupan pemeriksaan IVA di Ende sejak tahun 2016 hingga tahun 2018 adalah 5301 orang. Cakupan pemeriksaan IVA tidak berbanding lurus dengan jumlah tenaga kesehatan terlatih di wilayah Ende.

Kata Kunci: IVA, tenaga kesehatan terlatih, ende.

\section{KASUS LANGKA MOLA INVASIF SETELAH KEHAMILAN CUKUP BULAN, TERDIAGNOSIS DENGAN ULTRASONOGRAFI : SEBUAH LAPORAN KASUS DAN STUDI LITERATUR}

\author{
Agung Sari Wijayanti, Heru Priyanto
}

\section{Fakultas Kedokteran UNS, Rumah Sakit dr. Moewardi, Surakarta}

Latar belakang: Mola invasif dapat timbul dari berbagai peristiwa kehamilan meskipun dalam kebanyakan kasus didiagnosis setelah kehamilan mola. Mola invasif yang timbul dari kehamilan cukup bulan sebelumnya merupakan kasus yang jarang.

Tujuan: Mendemonstrasikan peran ultrasonografi dalam mendiagnosis mola invasif dan menjelaskan mengenai tatalaksana mola invasif pada kasus ini.

Laporan kasus: Wanita 52 tahun P4A0 datang ke Rumah Sakit dr. Moewardi, Surakarta dengan per- darahan dari jalan lahir, nyeri perut tidak khas, gangguan gastrointestinal dan diagnosis awal mola hidatidosa dimana didapatkan gambaran sonografi honey-comb appearance. Pasien tidak aktif secara seksual dengan riwayat kehamilan sebelumnya adalah kehamilan cukup bulan, 16 tahun yang lalu. Hasil pemeriksaan $\beta$-hCG $19.333 \mathrm{IU} / \mathrm{ml}$ dengan ultrasonografi dari divisi ginekologi onkologi menunjukan adanya lesi ireguler hipoekoik sebagian hiperekoik menginvasi miometrium dan hipervaskuler (color score 4) dengan gambaran end-lake pattern. Didapatkan diskontinuitas pada miometrium dan perimetrium dengan gambaran hipoekoik di cavum douglasi, sesuai gambaran perforasi. Pasien menjalani histerektomi atas indikasi perforasi. Hasil patologi anatomi menunjukan gambaran mola invasif.

Hasil: Perkembangan jaringan mola invasif dapat menembus miometrium, menyebabkan perforasi uterus. Ultrasonografi berperan penting dalam menegakan diagnosis mola invasif. Secara sonografis, penyakit trofoblas ganas bermanifestasi hiperekoik, dengan massa padat dan gambaran massa kistik hipervaskular. Kemoterapi merupakan terapi umum pada mola invasif, sedangkan histerektomi diindikasikan jika terdapat perforasi uterus. Pada penyakit trofoblas ganas usia tua dan tidak membutuhkan reproduksi kembali, histerektomi dianggap menurunkan mortalitas-morbiditas dan menurunkan kebutuhan siklus kemoterapi. Pasien menjalani kemoterapi EMA siklus 1 dan pemantauan $\beta$ hCG.

Kesimpulan: Kasus mola invasif yang berasal dari kehamilan cukup bulan merupakan kasus yang langka. Peran ultrasonografi dalam mendiagnosis mola invasif dengan tepat dapat menurunkan morbiditas dan mencegah kesalahan terapi. Kemoterapi merupakan terapi umum dan histerektomi dilakukan jika terdapat indikasi.

Kata kunci: Mola invasif, color doppler ultrasound, histerektomi.

\section{HUBUNGAN PEMAKAIAN AKSEPTOR DEPOT MEDROXYPROGESTERONE ACETATE (DMPA) SELAMA 12 BULAN DENGAN FAKTOR KOAGULASI}

Mega Sari Dewi, Anisya Friska Sari Hasibuan, Delfi Lutan, Elida R Sidabutar, Letta S Lintang, Hanudse Hartono, Rhiza Z Tala

Departemen Obstetri dan Ginekologi Fakultas Kedokteran Universitas Sumatera Utara Medan, Juli 2019 
Latar belakang: Sebagai salah satu program Safe Motherhood Initiative, program Keluarga Berencana diharapkan mampu menurunkan angka fertilitas di Indonesia. Kontrasepsi suntik yaitu DMPA, diyakini memiliki tingkat kegagalan $<0,5 \%$. Namun, salah satu efek DMPA yaitu perdarahan yang tidak teratur akibat gangguan faktor koagulasi.

Tujuan: Menilai hubungan pemakaian (DMPA) selama 12 bulan dengan faktor koagulasi.

Metode: Penelitian ini merupakan penelitian analitik dengan rancangan potong lintang yang dilakukan di Puskesmas Medan Johor pada bulan Juli 2017. Subjek penelitian berjumlah 40 wanita pengguna DMPA selama 12-16 bulan dipilih dengan metode consecutive sampling. Data dianalisis menggunakan uji T-berpasangan.

Hasil: Karakteristik subjek penelitian paling banyak dijumpai adalah kelompok usia 30-39 tahun $(72,5 \%)$, multipara $(82,5 \%)$, memiliki indeks massa tubuh overweight $(37,5 \%)$ serta memiliki siklus dan lama menstruasi tidak normal $(72,5 \%)$. Rerata nilai PT, TT dan APTT berturut-turut sebesar 13,19 $\pm 0,64$ detik, $17,17 \pm 1,28$ detik dan $0,65 \pm 4,19$ detik, serta tidak dijumpai adanya hubungan bermakna antara pemakaian DMPA selama 12 bulan dengan faktor koagulasi $(\mathrm{p}=0,948)$.

Kesimpulan: Tidak terdapat hubungan bermakna antara pemakaian DMPA selama 12 bulan dengan faktor koagulasi $(\mathrm{p}>0,05)$.

Kata kunci: Depot medroxyprogesterone acetate, perdarahan, faktor koagulasi.

\section{PERBANDINGAN NILAI PREDIKTIF ANTARA RISK-OF-MALIGNANCY INDEX (RMI) DAN KLASIFIKASI IOTA SIMPLE RULES DALAM PREDIKSI KEGANASAN PADA KASUS TUMOR OVARIUM DI RSUP DR. HASAN SADIKIN BANDUNG}

Toriq H, Pribadi A, Hidayat YM, Suardi D

Departemen Obstetri dan Ginekologi Fakultas Kedokteran Universitas Padjadjaran/ RSUP Dr. Hasan Sadikin Bandung

Tujuan: Penelitian ini bertujuan untuk mengevaluasi penggunaan dua metode diagnostik yang telah digunakan di RSHS, yaitu skor RMI dan Klasifikasi IOTA Rules untuk memprediksi keganasan suatu tumor ovarium selama periode 2017-2018.

Metode: Penelitian ini merupakan penelitian komparatif dengan pengambilan data secara retrospektif. Sumber data diperoleh dari rekam medis pasien yang menjalani operasi pengangkatan dan pemeriksaan histopalogis tumor ovarium. Dilakukan pengumpulan informasi mengenai data USG, kadar CA125, skor RMI, klasifikasi IOTA Simple Rules, dan membandingkannya dengan luaran histopatologis.

Hasil: Penelitian menunjukkan sensitivitas dan spesifisitas klasifikasi IOTA Simple Rules di RSHS masing-masing 94,23\% dan 97,06\%, dengan menggabungkan kelompok IOTA inkonklusif dengan kelompok ganas. Penghitungan sensitivitas dan spesifisitas skor RMI memberikan nilai $95,51 \%$ dan $14,71 \%$ dengan menggunakan cut-off-point skor RMI 200.

Kesimpulan: Sensitivitas dan spesifisitas klasifikasi IOTA Simple Rules lebih baik dibandingkan dengan skor RMI dalam memprediksi keganasan suatu tumor ovarium.

Kata kunci: Keganasan ovarium, IOTA, RMI.

\section{FAKTOR-FAKTOR YANG MEMPENGARUHI AKURASI RMI SKOR 2 PADA PENDERITA SUSPEK TUMOR GANAS OVARIUM DI RSUP DR. HASAN SADIKIN BANDUNG TAHUN 2017 - 2018}

Arieff Kustiandi, Yudi Mulyana Hidayat, Andi Kurniadi, RM Sonny Sasotya.

\section{Departemen Obstetri \& Ginekologi FK UNPAD/RSUP Dr. Hasan Sadikin Bandung}

Latar belakang: Keganasan ovarium memiliki angka morbiditas dan mortalitas yang tinggi karena umumnya ditemukan pada stadium lanjut.

Tujuan: Penelitian ini bertujuan untuk mengetahui spesifitas dan sensitivitas RMI skor 2 dalam menentukan keganasan ovarium. Kadar CA 125 dan RMI skor 2 kemudian dilihat histopatologinya sebagai gold standard. Penelitian ini dilakukan di RSUP dr. Hasan Sadikin Bandung periode Januari 2017 s.d. Desember 2018.

Metode: Penelitian ini menggunakan metode penelitian deskriptif dengan rancangan cross sectional. Sumber data diperoleh dengan meneliti rekam medis pasien di poli ginekologi onkologi RSUP Dr. Hasan Sadikin Bandung berdasarkan angka RMI skor 2 pada penderita suspek tumor ganas ovarium di RSUP Dr. Hasan Sadikin Bandung.

Hasil: Sampel berjumlah 172 dengan 31 berkategori jinak dan 141 berkategori ganas berdasarkan hasil histopatologinya. Analisis data dilakukan secara univariat dan bivariat. Data kategorik diuji dengan uji chi-square atau uji Exact Fisher. Data numerik digunakan uji-t tidak berpasangan atau uji Mann Whitney. Hasil penelitian menunjukkan nilai median CA 125 kelompok ganas dibanding kelompok jinak $(437,05$ vs 212,14$)$ bermakna secara statistik $p=0,001$ 
(nilai $\mathrm{p}<0,05$ ). Cut off point RMI skor 2 pada penelitian ini adalah > 200 dengan sensitivitas 95,74\% dan spesifisitas 16,12\%.

Kesimpulan: Penelitia ini adalah RMI skor 2 adalah cara yang berguna sebagai prediktor keganasan ovarium. Hal ini sangat berguna digunakan dengan kombinasi CA 125 dengan hasil pemeriksaan Ultrasonografi (USG) dan status menopause atau dikenal dengan Risk Malignancy Index (RMI skor 2 cut off point $>200$ ) dengan sensitivitas $95,74 \%$, spesifisitas $16,12 \%$ dan akurasi $81,39 \%$.

Kata kunci: CA 125, prediktor keganasan, RMI skor 2 .

\section{PROFIL LESI PRAKANKER SERVIKS DI RSUP SANGLAH DENPASAR PERIODE JANUARI - DESEMBER 2017}

Ida Bagus Rendra Kurniawan Artha ${ }^{1}$, I Nyoman Gede Budiana $^{2}$

${ }^{1}$ PPDS-1 Departemen/KSM Obstetri dan Ginekologi FK UNUD/RSUP Sanglah, ${ }^{2}$ Divisi Onkoginekologi, Departemen/KSM Obstetri dan Ginekologi FK UNUD/RSUP Sanglah

Latar belakang: Sampai saat ini kanker serviks masih menjadi masalah kesehatan perempuan di Indonesia. Kanker serviks berkembang dari lesi prakanker yang ditandai dengan adanya displasia pada epitel serviks. Dengan mendeteksi suatu lesi prakanker serviks dapat dilakukan penanganan yang adekuat dan menghambat perkembangannya menjadi kanker serviks. Tujuan dari studi ini adalah untuk mengetahui profil lesi prakanker serviks di RSUP Sanglah Denpasar periode Januari - Desember 2017.

Metode: Penelitian deskriptif observasional dengan pengambilan data berasal dari rekam medis pasien yang didiagnosa lesi prakanker serviks pada periode Januari - Desember 2017 di RSUP Sanglah Denpasar.

Hasil: Dalam kurun waktu 1 Januari 2017 - 31 Desember 2017, tercatat sebanyak 276 kasus $(2,88 \%)$ pasien lesi prakanker serviks yang berkunjung di Poliklinik Onkologi Ginekologi RSUP Sanglah Denpasar. Lesi prakanker serviks paling tinggi ditemukan pada kelompok umur 36-45 tahun (37,7\%), memiliki tingkat pendidikan dasar $(42,7 \%)$, IMT yang tergolong gemuk $(53,5 \%)$, multipara $(73,9 \%)$, berhubungan seksual pertama kali pada usia 16-20 tahun (41,3\%), menggunakan kontrasepsi berupa IUD $(41,4 \%)$. Hasil sitologi didapatkan Atypical Squamous Cells of Undetermined Significance (ASC-US) $(43,2 \%)$, hasil histopatologi berupa CIN I $(43,1 \%)$, penanganan lesi prakanker serviks yaitu krioterapi $(56,2 \%)$.

Kesimpulan: Profil penderita lesi prakanker serviks di RSUP Sanglah Denpasar periode Januari Desember 2017 paling banyak ditemukan pada kelompok umur 36-45 tahun, tingkat pendidikan dasar, IMT yang gemuk, multipara, berhubungan seksual pertama kali pada usia 16-20 tahun, pengguna kontrasepsi IUD. Hasil sitologi terbanyak didapatkan ASC-US, hasil histopatologi biopsi paling banyak berupa CIN I, penanganan lesi prakanker serviks paling banyak dilakukan yaitu krioterapi.

Kata kunci: Lesi prakanker serviks, kanker serviks.

\section{PROPORSI KESINTASAN LIMA TAHUN PASCA RADIASI PASIEN KARSINOMA SEL SKUAMOSA SERVIKS STADIUM IIB-IIIB DAN HUBUNGANNYA DENGAN INFEKSI HPV}

Syifa Mardhatillah Syafitri ${ }^{1 *}$, Andrijono $^{2}$

${ }^{1}$ Department of Obstetrics and Gynecology, Universitas Indonesia, Cipto Mangunkusumo hospital

${ }^{2}$ Division of Oncology Gynecology, Department of Obstetrics and Gynecology, Universitas Indonesia, Cipto Mangunkusumo Hospital

*Korespondensi: sms_ifa@yahoo.com

Tujuan: Untuk mengetahui proporsi kesintasan lima tahun pasca radioterapi penderita KSS serviks stadium IIB-IIIB dan hubungannya dengan infeksi HPV serta faktor lain yang mempengaruhi

Metode: Penelitian ini merupakan penelitian kohort untuk menilai kesintasan pasien lima tahun setelah terapi radiasi lengkap. Populasi terjangkau adalah penderita karsinoma serviks stadium IIB dan IIIB dengan hasil biopsi serviks KSS yang telah menjalani radioterapi di RSCM dan dilakukan pemeriksan DNA HPV pre dan post radiasi. Dilakukan penilaian kesintasan pasien serta dilakukan penilaian hubungan kesintasan dengan infeksi HPV dan faktor lain yang mempengaruhi. Analisis statistik digunakan dengan uji prognostik Kaplan Meier.

Hasil: Dari 31 sampel penelitian pendahuluan, hanya 27 subjek yang dapat difollow up. Angka kesintasan lima tahun adalah sebesar 35,5\%. Tidak didapatkan hubungan yang bermakna antara kesintasan dengan infeksi HPV, persistensi infeksi HPV, lama radiasi, LVSI, stadium, diferensiasi, ukuran tumor dengan masing-masing nilai $\mathrm{p} 0,921,0,586,0,718,0,65$, 0,139 , 0,78, dan 0,139 . Terdapat hubungan yang bermakna antara respon radiasi dengan survival, dengan median time survival 2 tahun ( $\mathrm{p} 0,016)$. 
Kesimpulan: Angka kesintasan 5 tahun pasca radiasi pada penderita kanker serviks stadium IIB-IIIB adalah $35,5 \%$. Tidak ada hubungan yang bermakna antara infeksi HPV, LVSI, stadium, differensiasi dan ukuran tumor dengan kesintasan 5 tahun pasca radiasi. Terdapat hubungan yang bermakna antara respon radiasi dengan kesintasan 5 tahun pasca radiasi.

Kata kunci: Kanker serviks, kesintasan, infeksi HPV, tipe HPV, radiasi, prognosis.

\section{HUBUNGAN KUALITAS HIDUP DAN KEBUTUHAN PERAWATAN PALIATIF PASIEN KANKER GINEKOLOGI DI RUMAH SAKIT HASAN SADIKIN}

Rizna Tyrani Rumanti, A. Yogi Pramatirta, Ali Budi Harsono, Jusuf Sulaeman Effendi

Departemen Obstetri dan Ginekologi Fakultas Kedokteran Universitas Padjadjaran / RSUP Dr. Hasan Sadikin Bandung

Latar belakang: Perawatan paliatif terutama bertujuan untuk meningkatkan kualitas hidup pasien dan keluarga mereka. Perawatan paliatif saat ini secara keliru telah berubah menjadi perawatan akhir-hidup.

Tujuan: Tujuan penelitian ini adalah untuk mengetahui bagaimana hubungan kualitas hidup dan kebutuhan perawatan paliatif pada pasien kanker ginekologi yang dirawat di Rumah Sakit Hasan Sadikin pada bulan November-Desember 2018.

Metode: Subjek penelitian ini adalah seluruh pasien kanker ginekologi yang dirawat di Rumah Sakit Hasan Sadikin pada bulan November-Desember 2018. Penelitian ini merupakan studi observasional dengan rancangan case-control. Data yang diperoleh dianalisis secara bivariat dengan menggunakan chi square dengan $\alpha=0,05$, untuk mengetahui hubungan antara kualitas hidup dengan kebutuhan perawatan paliatif.

Hasil: Karakteristik pasien kanker ginekologi yang dirawat di Rumah Sakit Hasan Sadikin pada bulan November-Desember 2018 yang terbanyak berusia $>50$ tahun $(65,67 \%)$, pendidikan dasar $(70,15 \%)$, ibu rumah tangga $(89,55 \%)$, pendapatan di atas upah minimum regional $(61,19 \%)$, tujuan rawat inap terbanyak adalah kemoterapi $(47,76 \%)$ dan tipe kanker terbanyak adalah karsinoma serviks $(43,28 \%)$. Subjek penelitian dengan skor paliatif $\geq 4$ sebanyak 25 orang $(37,31 \%)$. Keluhan yang terbanyak adalah berat badan turun dan tidak nafsu makan (86,57 \%). Kualitas hidup pasien kategori baik sebanyak 29 orang, sedang 36 orang dan kurang 2 orang. Kualitas hidup pasien kanker ginekologi berhubungan dengan kebutuhan perawatan paliatif dengan nilai signifikansi p 0,004.
Kesimpulan: Kualitas hidup berhubungan dengan skor paliatif, semakin rendah skor paliatif maka kualitas hidup semakin baik.

Kata kunci: Kanker ginekologi, kualitas hidup, skor paliatif.

\section{PERAN KRITERIA KLINIS DAN PATOLOGI ANATOMI DALAM MENENTUKAN TUMOR PRIMER PADA KASUS KANKER ENDOMETRIOID: SEBUAH LAPORAN KASUS}

David Tambunan ${ }^{1}$, Fara $\mathrm{VS}^{2}$

${ }^{1}$ Department of Obstetrics and Gynecology, Faculty of Medicine University of Indonesia- Cipto

Mangunkusumo hospital

${ }^{2}$ Department of Obstetrics and Gynecology, Fatmawati General Hospital, south of Jakarta

Angka kejadian sinkronisasi kanker primer dari endometrium dan ovarium ditemukan pada $10 \%$ pada populasi wanita dengan kanker ovarium dan $5 \%$ pada populasi wanita dengan kanker endometrium. Sebuah kasus di RS Fatmawati menunjukkan kasus kanker ovarium tipe endometrioid carcinoma dengan metastasis ke endometrium. Wanita 48 tahun dengan kanker ovarium stadium lanjut dengan riwayat operasi salpingektomi kiri 2 tahun yang lalu dengan hasil patologi didapatkan adenocarcinoma ovarium. Paska total histerektomi dan salpingooforektomi kanan, hasil patologi anatomi menyatakan endometrioid carcinoma grade 1 pada endometrium dan ovarium kanan, tumbuh $<1 / 2$ ketebalan myometrium. Tujuan tulisan ini untuk menjabarkan beberapa data seperti kesamaan histologi dari kanker, adanya invasi miometrium dari kanker endometrium, adanya invasi pembuluh darah kanker endometrium dan ovarium, tidak ada bukti penyebaran dari kanker, kanker ovarium unilateral atau bilateral, kanker ovarium pada daerah parenkim ataupun lapisan luar ovarium dan ketidaksamaan gambaran genetik molekuler ataupun kariotiping pada tumor kedua tempat untuk menegakkan asal tumor primer, sehingga dapat tepat menegakkan staging dan menetapkan tatalaksana.

Kata kunci: Endometrioid carcinoma, Synchronous Endometrium and Ovarium Carcinoma (SEOC).

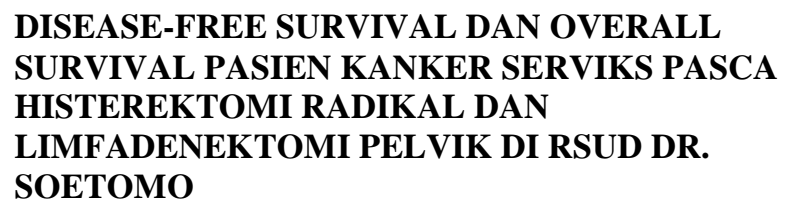

DISEASE-FREE SURVIVAL DAN OVERALL SURVIVAL PASIEN KANKER SERVIKS PASCA HISTEREKTOMI RADIKAL DAN LIMFADENEKTOMI PELVIK DI RSUD DR. SOETOMO 
Ardi Eko Marsanto

\section{RSUD Sabu Raijua, Nusa Tenggara Timur}

Latar belakang: kanker serviks masih menjadi masalah besar di negara berkembang. Pada stadium IB sampai IIB, histerektomi radikal dan limfadenektomi pelvik atau sering disebut Radical Hysterectomy and Pelvic Lymph-Node Dissection (RH-PLND), dengan atau tanpa Neoadjuvant Chemotherapy (NAC) dan Adjuvant Therapy (AT), menjadi pilihan terapi karena akses menuju kemoradioterapi konkuren di RSUD Dr. Soetomo masih terbatas, namun belum ada data tentang kesintasan (survival) pada pasien-pasien tersebut.

Tujuan: mengetahui rekurensi, mortalitas, Disease-Free (DFS) dan Overall Survival (OS) tiga tahun pada pasien kanker serviks pasca RH-PLND, dengan atau tanpa NAC dan AT.

Metode: deskriptif retrospektif observasional terhadap rekurensi, mortalitas, DFS dan OS dari 60 pasien kanker serviks pasca RH-PLND di RSUD Dr. Soetomo periode tahun 2012 - 2014.

Hasil: sampel dibagi menjadi empat kelompok [kelompok 1: RH-PLND; kelompok 2: RH-PLND + AT (kelompok operabel); kelompok 3: NAC + RH-PLND + AT; kelompok 4: NAC + RH-PLND (kelompok inoperabel)]. Didapatkan total delapan rekurensi dan enam mortalitas, dengan DFS dan OS 3 tahun tertinggi pada kelompok $2(91,7 \%)$ dan $1(100 \%)$, berurutan. Kelompok 3 memiliki DFS dan OS 3 tahun terendah dibanding semua kelompok (67,4 dan 65,6\%, berurutan). Rekurensi dan mortalitas terbanyak didapatkan pada kelompok pasien inoperabel (lima dan empat pasien, berurutan).

Kesimpulan: kesintasan pasien yang mendapat tiga modalitas terapi (neoajuvan, operasi dan ajuvan) tidak memiliki prognosis yang lebih baik. Tindakan histerektomi radikal dan limfadenektomi pelvik, dengan atau tanpa pemberian terapi neoajuvan dan ajuvan sesuai kondisi klinis, masih merupakan terapi yang sesuai untuk pasien kanker serviks di RSUD Dr. Soetomo.

Kata kunci: Kanker serviks, histerektomi radikal, kesintasan.

\section{HUBUNGAN TIPE HISTOPATOLOGI DENGAN RESPON KEMOTERAPI NEOADJUVANT PADA KANKER SERVIKS STADIUM IB2 DAN IIA2}

Gistin Husnul Khatimah

Bagian/SMF Obstetri dan GinekologiFakultas Kedokteran Universitas Andalas, RSUP Dr. M. Djamil Padang

Latar belakang: Kanker serviks menempati urutan keempat di seluruh dunia dan urutan kedua di Indonesia yang paling umum terjadi pada wanita. Kemoterapi telah dievaluasi sebagai salah satu strategi pengobatan kanker serviks stadium IB2 dan IIA2. Namun penggunaan kemoterapi neoadjuvant masih kontroversi, pada pasien yang resisten dengan kemoterapi akan menunda pemberian terapi definitif, sehingga sangat penting untuk menemukan penanda yang dapat mengidentifikasi pasien mana yang relatif lebih resisten terhadap kemoterapi. Tipe squamous cell carcinoma (SCC) diketahui memiliki respon kemoterapi neoadjuvant yang lebih baik dibandingkan dengan nonsquamous cell carcinoma (NSCC) namun belum ada penelitian yang dilakukan di RSUP M Djamil Padang mengenai hal ini sebelumnya.

Tujuan: Untuk melihat Hubungan Tipe Histopatologi Dengan Respon Kemoterapi Neoadjuvant Pada Kanker Serviks Stadium IB2 Dan IIA2.

Metode: Penelitian ini merupakan studi analitik cohort yang dilakukan di RSUP Dr. M. Djamil Padang pada 35 sampel pasien kanker serviks stadium IB2 dan IIA2 yang diberikan kemoterapi neoadjuvant. Pengambilan sampel dilakukan dengan teknik consecutive sampling. Data meliputi hasil gambaran histopatologi serta hasil pemeriksaan ultrasonografi sebelum dan sesudah diberikan kemoterapi neoadjuvant. Analisis data mengunakan uji Chi-Square.

Hasil: CR+PR pada kelompok SCC adalah sebesar $32 \%$ dan NSCC adalah 50\%, sedangkan SD+PD adalah sebesar $68 \%$ pada kelompok SCC dan 50\% pada kelompok NSCC.

Kesimpulan: Tidak terdapat hubungan yang bermakna antara tipe histopatologi dengan respon kemoterapi neoadjuvant pada kanker serviks stadium IB2 dan IIA2 ( $\mathrm{p}=0.44)$.

Kata kunci: Histopatolgi, kemoterapi, kanker serviks. 


\section{UROGINEKOLOGI}

\section{NEOVAGINALISASI DAN ANASTOMOSIS UTEROVAGINA PADA AGENESIS CERVIX DAN VAGINA PROKSIMAL DISERTAI HEMATOMETRA DAN HEMATOKOLPOS DENGAN MENGGUNAKAN MODIFIKASI VAGINAL MOLD}

Benny Yafet Lalompoh, Kadek Fajar Marta

\section{PPDS-I Departemen/KSM Obstetrik dan Ginekologi FK UNUD/RSUP Sanglah \\ Divisi Uroginekologi, Departemen/ KSM Obstetrik dan Ginekologi FK UNUD/ RSUP Sanglah}

Tujuan: Melaporkan kasus neo-vaginalisasi dan anastomosis uterovagina menggunakan modifikasi vaginal mold sebagai penatalaksanaan agenesis cervix dan vagina proksimal disertai hematometra dan hematokolpos.

Kasus: Pasien perempuan 26 tahun, menikah, rujukan dari Sumba (NTB) ke RSUP Sanglah Denpasar dengan diagnosis agenesis cervix-vagina. Pasien mengeluhkan nyeri perut dan tidak pernah menstruasi. Pada pemeriksaan fisik didapatkan vagina sepanjang 3 $\mathrm{cm}$, tidak tampak adanya portio, teraba bulging mass 5 $\mathrm{cm}$ dari anal kanal kesan hematokolpos. Teraba diskontinuitas pada dinding vagina posterior sampai menembus anus ukuran $\pm 1.5 \mathrm{~cm}$ merupakan fistula rektovagina, dicurigai sebagai komplikasi tindakan evakuasi clot tahun 2016-2018 di RS Sumba. Pada pemeriksaan USG, didapatkan uterus ukuran $7.4 \times 5.3 \times 7.7 \mathrm{~cm}$, tampak massa hipoechoic intrauterin ukuran $1.7 \times 2.6 \mathrm{~cm}$ mengesankan suatu hematometra, tidak tampak cervix dan vagina proksimal. Preoperasi, pasien diberi terapi depoprovera injeksi untuk menangani hematokolpos dan hematometra, kemudian dilakukan tindakan operatif neovaginalisasi dan anastomosis uterovagina lalu dipasang Foley kateter intrauterin dengan modifikasi vaginal mold, serta dilakukan repair fistula rektovagina. Pasca operasi pasien kontrol rutin untuk mengantisipasi kemungkinan terjadinya stenosis vagina.

Diskusi: Kelainan kongenital agenesis vagina baik total atau sebagian terjadi akibat gangguan perkembangan duktus Mulleri dengan kejadian berkisar antara 1: 4.000-10.000 kelahiran. Etiologi secara pasti belum jelas, beberapa peneliti mengatakan hal ini terjadi karena gangguan pada gen autosomal resesif, gangguan pada transmitted sex-linked autosomal dominant, adanya hormon antimullerian atau pengaruh obat-obatan seperti thalidomide. Penanganan dapat dilakukan dengan metode operatif maupun non-operatif. Pada kasus ini metode operatif dipilih dengan menggunakan teknik modifikasi vaginal mold karena teknik ini lebih mudah dikerjakan dan menggunakan alat sederhana.

Kesimpulan: Neovaginalisasi dan anastomosis uterovagina dengan menggunakan modifikasi vaginal mold pada pasien dengan agenesis cervix dan vagina proksimal merupakan salah satu pilihan tatalaksana dengan teknik yang lebih mudah dikerjakan dengan luaran optimal.

Kata kunci: Neovaginalisasi, Agenesis CervixVagina, Vaginal Mold.

\section{KARAKTERISTIK PENDERITA SEPTUM VAGINA YANG DILAKUKAN TINDAKAN INSISI SEPTUM DI RSUD DR. SOETOMO SURABAYA TAHUN 2014-2018}

\section{Rizalul Rosyiadi, Gatut Hardianto}

Departemen Obstetri dan Ginekologi Fakultas Kedokteran Universitas Airlangga Surabaya, Indonesia

Latar Belakang: Anomali vagina mencakup 10\% dari abnormalitas saluran reproduksi wanita. Anomali vagina dapat diikuti anomali saluran genital dan ekstragenital. Salah satu yang tersering adalah septum vagina. Septum vagina dapat muncul dengan amenore primer, nyeri siklik panggul atau perut. Distensi vagina dapat terjadi karena obstruksi, ditandai dengan nyeri punggung, nyeri buang air besar, atau kesulitan buang air kecil.

Metode: Penelitian ini adalah penelitian retrospektif observasional di RSUD Dr. Soetomo Surabaya, dengan sampel pasien septum vagina yang dirawat dan ditatalaksana dari Januari 2014 hingga Desember 2018. Didapatkan 30 pasien. Data diambil dari rekam medis. Dilakukan penjabaran karakteristik, komplikasi, tindakan yang dilakukan dan keluhan paska operasi.

Hasil: Dari 30 penderita septum vagina, 14 penderita dilakukan tindakan insisi/eksisi dan drainase. Dari 30 pasien tersebut, terbanyak usia $<20$ tahun $(22$ pasien), 20-35 tahun (7 pasien) dan sisanya $>35$ tahun (1 pasien). Mayoritas pasien belum menikah (24 pasien).

Terkait riwayat menstruasi, 15 pasien $(50 \%)$ pernah menstruasi dan $15(50 \%)$ lainnya tidak. Penyerta terbanyak adalah hematometra-hematocolpos (12 pasien). Dari 30 pasien semua dilakukan USG, 5 pasien dilakukan MRI. Berdasarkan jenis tindakan, 10 pasien dilakukan insisi-drainase, 8 pasien dilakukan pembuatan neo-vagina, 4 pasien dilakukan eksisi-drainase, 4 pasien belum dilakukan tindakan. Dari 30 pasien, 9 pasien 
pernah dilakukan repair. Mayoritas pasien (26 pasien) tidak melaporkan keluhan paska operasi, 3 pasien mengeluhkan nyeri akibat stenosis ulang.

Kesimpulan: Septum vagina merupakan kelainan pada wanita yang ditandai dengan adanya sekat pada vagina. Mayoritas pasien septum vagina di RSUD dr. Soetomo pada periode Januari 2014-Desember 2018 berusia muda dengan sebagian pasien masih mengalami menstruasi. Penyerta terbanyak adalah hematometrahematocolpos. Mayoritas pasien dilakukan insisidrainase. Mayoritas pasien tidak melaporkan keluhan paska operasi.

\section{ANALISIS FAKTOR RESIKO GEJALA PROLAPS ORGAN PANGGUL (POP) PADA PASIEN MENOPAUSE DI POLI GERIATRI RSUD DR. SOETOMO}

Rizqy Rahmatyah $^{1}$, Gatut Hardiyanto ${ }^{2}$, Dwi Susanti ${ }^{3}$

\section{${ }^{1}$ Mahasiswa S1 Pendidikan Dokter \\ ${ }^{2}$ Staf Pengajar Departemen Obstetri dan \\ Ginekologi Fakultas Kedokteran Universitas Airlangga, ${ }^{3}$ Staf Pengajar Departemen Ilmu Kesehatan Masyarakat-Kedokteran Pencegahan Fakultas Kedokteran Universitas Airlangga}

Latar Belakang: Prolapse organ panggul (POP) didefinisikan penurunan atau herniasi dari organ panggul yang meliputi uterus (uterine prolaps), ujung vagina (apical vaginal prolaps), vagina anterior (cystocele), atau vagina posterior (rectocele). Pelvic Organ Prolapse Distress Inventory-6 (POPDI-6 merupakan satu bentuk kuisioner guna mengetahui kualitas hidup bagi wanita dengan kelainan otot panggul. Penelitian ini bertujuan untuk mengetahui karakteristik pasien menopause dengan tanda-tanda gejala POP di Poli Geriatri RSUD Dr. Soetomo.

Metode: Penelitian ini adalah penelitian analitik observasional dengan metode cross-sectional menggunakan teknik pusposive sampling. Penelitian dilakukan pada Agustus 2016. Populasi dalam penelitian ini adalah pasien Poli Geriatri RSUD Dr. Soetomo. Kuesioner digunakan untuk mengumpulkan data. SPSS digunakan untuk mendapatkan analisa data.

Hasil: Terdapat 56 pasien yang menjadi subyek pada penelitian ini. Data dianalisis dengan uji chisquare, mann-whitney dan uji korelasi Spearman's rho menggunakan SPSS 21.0. Didapatkan 13 responden (23.2\%) yang memiliki gejala POP berdasar POPDI-6, namun dengan hasil skor tertinggi hanya 45.8 (cut-off 75). Korelasi signifikan didapatkan pada hubungan usia awal menopause dengan gejala berkemih tidak tuntas $(\mathrm{p}=0.036)$.
Kesimpulan: Tidak terdapat hubungan signifikan antara gejala POP dengan variable yag diteliti (usia, lama menopause, jumlah paritas, riwayat persalinan pervaginam), namun terapat hubungan signifikan dengan usia awal menopause dan merupakan factor resiko gejala tonjolan turun dari vagina dan buang air besar tidak lancer pada pasien di Poli Geriatri RSUD Dr Soetomo.

Kata kunci: Prolapse Organ Panggul, POPDI-6, Menopause, Geriatri.

\section{FEMALE GENITAL MUTILATION TIPE IV}

Annisa Ika Nurrahmayanti Syakir ${ }^{1}$, Irwan ${ }^{2}$, Trika Irianta $^{3}$

${ }^{1}$ Mahasiswa Fakultas Kedokteran Universitas Hasanuddin, ${ }^{2}$ Department Obstetri \& Ginekologi RS Bhayangkara Makassar, ${ }^{3}$ Divisi Uroginekologi, Department Obstetri \& Ginekologi Fakultas Kedokteran Universitas Hasanuddin, POGI Cabang Makassar

Latar Belakang: Female Genital Mutilation (FGM) atau dikenal dengan sunat pada perempuan, ialah segala jenis tindakan yang melibatkan pemotongan sebagian/seluruh alat kelamin eksternal perempuan, atau perlukaan lain pada alat kelamin perempuan tanpa alasan medis yang mendasarinya. Sekitar 200 juta perempuan di 30 negara diperkirakan telah menjalani praktek FGM. Resolusi PBB tahun 2012 memandang FGM sebagai tindakan kekerasan terhadap perempuan dan anak perempuan. Beberapa upaya telah dilakukan, namun FGM sulit untuk dihilangkan. Hal ini karena pada negara-negara yang menganut FGM memiliki akar sosial yang dalam. FGM melanggar hak asasi manusia dan hak untuk mendapatkan kesehatan yang layak, oleh karena itu kami melaporkan kasus ini.

Tujuan: Melaporkan kasus FGM tipe IV di RS. Bhayangkara Makassar.

Kasus: Seorang perempuan usia 23 tahun datang dengan keluhan tidak dapat berhubungan seksual dengan pasangannya karena vagina yang tertutup. Riwayat pernah dilakukan tindakan tradisional berupa penjahitan pada alat kelamin sewaktu berumur delapan tahun di negara asalnya Somalia. Pasien telah menikah sejak tiga bulan yang lalu dan sejak saat itu tidak dapat berhubungan seksual normal dengan pasangannya karena vagina yang tertutup dan meminta untuk dilakukan pencabutan/perlepasan penjahitan. Pada pemeriksaan ginekologi, tampak labia minora kiri dan kanan menyatu membentuk dinding dan menutup orificium vagina, tampak lubang ukuran sekitar 1 x 1 $\mathrm{cm}$ di bagian antero lateral introitus vagina. Pemeriksa- 
an ultrasonografi didapatkan organ reproduksi dalam batas normal. Pasien kemudian di diagnosis dengan sinekia labia minora et causa FGM Tipe IV.

Kesimpulan: FGM merupakan tindakan ekstrim terhadap kehidupan perempuan yang berhubungan erat dengan kultur sosial, kesehatan fisik, dan psikologis dan sangat bertentangan dengan hak asasi perempuan. Perlunya sosialisasi pada masyarakat maupun praktisi kesehatan dalam menangani perempuan dengan FGM agar tindakan ini tidak dilakukan.

\section{KEBERHASILAN PENETRASI VAGINA PASCA MODALITAS TERAPI GINEKOLOGIS PADA 374 PASIEN VAGINISMUS}

\section{Robbi Asri Wicaksono}

\section{Bagian Obstetri \& Ginekologi Rumah Sakit Ibu Anak Limijati Bandung}

Latar Belakang: Vaginismus menurut ICD-10 merupakan penyakit organ reproduksi dan saluran kemih, dengan kode N94.2 yaitu kaku otot dinding vagina yang tidak bisa dikendalikan oleh penderitanya sehingga menyebabkan kendala maupun kegagalan penetrasi. Penanganan fisik vaginismus belum menjadi perhatian, karena selama ini dikelirukan sebagai "penyakit yang bersumber dari pikiran". Dilatasi adalah upaya fisik yang terbukti bisa menghasilkan keberhasilan penetrasi. Pada kasus vaginismus dengan derajat menengah-berat, pasien tidak bisa melakukan dilatasi, sehingga dibutuhkan upaya tertentu agar dilatasi bisa terjadi. Prosedur dilatasi berbantu memadukan proses anestesi, injeksi botulinum toxin, dilatasi progresif, dan supervisi dilatasi, dengan keberhasilan penetrasi yang tinggi.

Tujuan: Memaparkan aspek diagnostik dan penatalaksanaan vaginismus secara ginekologis.

Metode: Studi deskriptif ini merupakan pelayanan pasien vaginismus di RSIA Limijati Bandung, periode Januari 2017-April 2019, berjumlah 374 pasien.

Hasil: Rata-rata usia 30,3 tahun (21-56 tahun). Lama menikah rata-rata 3,97 tahun (1 bulan-25 tahun). Vaginismus primer 366 kasus $(97,8 \%)$, vaginismus sekunder 8 kasus. Penanganan psikis sebelumnya (Psikiater dengan obat penenang) pada 63 kasus. Terdapat 4 kasus yang sebelumnya telah dilakukan tindakan pembedahan pada vagina. Derajat keparahan vaginismus pasien, I (1), II (9), III (67), IV (236), V (61). Terdapat 1 kasus kelainan struktur genitalia yaitu sinekia labia minora. Jumlah prosedur dilatasi berbantu adalah 235. Pada 3 kasus ditemukan kelainan struktur genitalia, yaitu 1 kasus septum transversum 1/3 atas, dan 2 kasus septate hymen. Keberhasilan melakukan dilatasi mandiri pasca prosedur 99,5\%. Keberhasilan pemeriksaan medis melalui vagina 97,7\%. Rata-rata keberhasilan penetrasi penis $75,9 \%$ dalam 4,6 minggu. Pasca prosedur dilatasi berbantu, pasien mengalami kehamilan alami pada 55 pasien. Pada 43 kasus pasca prosedur, dilakukan penanganan bersama psikiater untuk menghilangkan hambatan psikis yang masih ada, sehingga hasil yang diharapkan tercapai lebih lancar dan cepat.

Kesimpulan: Upaya diagnostik dan penanganan secara fisik memberikan hasil yang nyata dan segera. Diperlukan penelitian lebih lanjut agar aspek medis vaginismus bisa terungkap lebih banyak. dilatasi

Kata Kunci: Vaginismus, penetrasi vagina,

\section{LAPORAN KASUS SEORANG ANAK DENGAN SINDROM MRKH DAN VACTERL}

T Mirza Iskandar ${ }^{1}$, Erwinanto $^{2}$, Lubena $^{1}$

${ }^{1}$ Divisi Ginekologi Onkologi, ${ }^{2}$ Divisi Uroginekologi, Departemen Obstetri dan Ginekologi, Fakultas Kedokteran Universitas Diponegoro, RSUP dr. Kariadi, Semarang

Latar Belakang: VACTERL (Vetebral Defect, Anal Atresia, Cardiac Defect, Tracheoesophageal Fistula/ Atresia, Renal Defect, Limb Defect, amd Limb Defect) dan sindrom Mayer-Rokitansky-Kuster-Hauser merupakan keadaan yang jarang ditemui. Kookurensi VACTERL dan sindrom MRKH sangat langka dan belum banyak laporan kasus yang dipublikasikan. Meskipun dengan koreksi bedah yang optimal, pasien dengan kelainan VACTERL memiliki risiko mengalami nyeri punggung, inkontinensia fekal dan gangguan fungsional (anomali ekstremitas). Tantangan medis yang timbul bergantung pada jenis dan tingkat keparahan malformasi yang timbul. Perempuan dengan sindrom MRKH yang tidak dapat hamil dapat memicu stres, gangguan psikologis dan kepercayaan diri. Pelaporan kasus-kasus yang jarang ditemukan sangatlah penting untuk memperluas pengetahuan mengenai etiologi, tatalaksana, dan keluaran pada keadaan tersebut.

Laporan Kasus: Kami melaporkan suatu kasus yang jarang terjadi, seorang anak 10 tahun dengan MRKH dan suspek VACTERL, dengan keluhan utama nyeri perut yang berulang setiap bulan dan pasien belum pernah menstruasi. Pasien mengalami perkembangan seksual sekunder normal (tanner 3). Pasien terlahir dengan atresia ani dan menjalani colostomy dan surgical repair pada usia 1 tahun. Pasien juga mengalami inkontinensia urine dan alfi, serta menjalani operasi daerah lumbal usia 3 tahun, kedua tungkai pasien 
mengalami equinovarus. Hasil pemeriksaan karyotyping normal 46, XX. Problem utama pasien adalah nyeri perut berulang setiap bulan, diputuskan dilakukan pengangkatan uterus. Hasil operasi didapatkan uterus bicornu dengan hematometra. Tidak didapatkan serviks dan vagina. Didapatkan bilateral hematosalping dan kista coklat ovarium kanan.

Kesimpulan: Kelainan VACTERL dan sindrom MRKH merupakan kejadian yang langka. Kami telah melaporkan seorang anak usia 10 tahun dengan kelainan tersebut. Pemahaman dan ketelitian klinispenting untuk menegakkan diagnosis. Edukasi dan konseling terhadap pasien dan keluarga sebelum dan selama menjalani terapi sangat penting dilakukan. Bantuan psikologis dan medis akan membantu dalam menangani kasus tersebut terutama berkaitan dengan kehidupan seksual dan reproduksi pasien.

Kata kunci: MRKH, VACTERL, atresia ani

\section{KORELASI ANTARA KADAR (HS-CRP) HIGH SENSITIVITY-C-REACTIVE PROTEIN DAN KADAR BDNF(BRAIN DERIVED NEUROTROPHIC FACTOR) URIN MENOPAUSE DENGAN OVERACTIVE BLADDER}

Roy Christian Bangun, Nutrisia Latjindung, Edy Ardiansyah, M. Fidel Ganis Siregar, Herbert Sihite, M. Rhiza Z Tala, Dwi Faradina

Departemen Obstetri dan Ginekologi Fakultas Kedokteran Universitas Sumatera Utara, RSUP H. Adam Malik Medan

Latar Belakang: Terdapat setidaknya 50-100 juta pasien overactive bladder diseluruh dunia dan wanita menopause memiliki risiko lebih tinggi terkena overactive bladder. Overactive bladder lebih rentan pada wanita dengan kadar $C$-reactive protein (CRP). Digunakannya Brain Derived Neurothropic Factor (BDNF) penanda lebih spesifik.

Tujuan: Penelitian menilai korelasi antara kadar High-Sensitivity- $C$-reactive protein (hs-CRP), kadar Brain Derived Neurotrophic Factor (BDNF) urin menopause dengan overactive bladder.

Metode: Penelitian analitik observasional, desain penelitian case control pada wanita paramedis menopause mengalami overactive bladder dan tidak mengalami overactive bladder diRSUP Adam Malik bulan januari 2019. Sampel dengan metode nonprobability, teknik consecutive sampling. Anamnesis menentukan derajat $\mathrm{OAB}$ dengan skor OAB, diukur kadar hs-CRP dan BDNF dilaboratorium terpadu. Data terdistribusi normal digunakan uji korelasi Pearson, data tidak terdistribusi normal digunakan ujikorelasi Spearman.

Hasil: Nilai rerata hs-CRP pasien OAB 1,33 $\pm 0,23$, pasien tanpa OAB $0,66 \pm 0,34$. Pasien dengan OAB, nilai rerata $\mathrm{BDNF} 430,87 \pm 73,58$, tanpa OAB 230,97 $\pm 29,88$. Kadar hs-CRP urin pasien OAB adalah>1,04 mg/L sebanyak 38 pasien (100\%), pasien tidak OAB <1,04 $\mathrm{mg} / \mathrm{L}$ sebanyak 37 pasien $(97,3 \%)$ dengan $\mathrm{p}=0,001$. Kadar BDNF pasien OAB >305,5 pg/L, 38 pasien (100\%) dan tidak OAB kadar $>305,5$ pg/L sebanyak 38 pasien $(100 \%)$, nilai $\mathrm{p}=0,001$. Korelasi antara hs-CRP dan BDNF pasien OAB, didapatkan korelasi positif sedang dengan $\mathrm{r}=0,525$ dan $\mathrm{p}<0,001$. Sedangkan korelasi antara hs-CRP dan BDNF pasien tanpa OAB, didapatkan korelasi tidak signifikan, $r=0,128$ dan $\mathrm{p}=0,442(\mathrm{p}<0,001)$.

Kesimpulan: Terdapat peningkatan kadar hs-CRP dan kadar BDNF urin menopause dengan OAB dibandingkan dengan non $\mathrm{OAB}$. Terdapat peningkatan rerata kadar hs-CRP dan BDNF urin menopause dengan $\mathrm{OAB}$ dibandingkan non OAB. Terdapat korelasi positif sedang yang signifikan antara kadar hs-CRPdan kadar BDNF urin menopause dengan overactive bladder.

Kata Kunci: High sensitivity-C-reactive protein, Brain Derived Neurotrophic Factor, overactive bladder, menopause.

\section{DYSPAREUNIA DAN OBSTETRICS ANAL SPINCHTER INJURIES (OASIS)}

M. Dimas Abdi Putra ${ }^{1}$, Eighty Mardian Kurniawati ${ }^{2}$, Hari Paraton ${ }^{2}$, Gatut Hardianto ${ }^{3}$, Azami Denas ${ }^{2}$

${ }^{1}$ PPDS-1 Obstetri dan Ginekologi RSUD dr. Soetomo/FK Universitas Airlangga Surabaya, ${ }^{2}$ Staf Pengajar Divisi Uroginekologi Dept Obstetri dan Ginekologi RSUD dr. Soetomo/FK Universitas Airlangga Surabaya

Latar Belakang: Dyspareunia pasca melahirk-an merupakan keluhan yang umum terjadi. Studi retrospektif menunjukkan bahwa derajat laserasi perineum merupakan salah satu independent risk factor untuk terjadinya dyspareunia, yang dapat bertahan hingga enam bulan pasca melahirkan. Beberapa bahkan melakukan abstinensia hingga 14 tahun. Penelitian ini dilakukan untuk menganalisis hubungan antara dyspareunia dengan kasus OASIs.

Tujuan: Melakukan analisis hubungan antara dyspareunia dengan kasus OASIs.

Metode: Melakukan penelusuran database dari Cochrane, PubMed dan Elsevier Sciencedirect dengan jenis penelitian case-control, dapat diakses full text, berbahasa Inggris dengan luaran dyspareunia. Kata 
kunci menggunakan terminologi yang disepakati oleh MesH (PubMed) seperti dyspareunia, sexual, episiotomy, OASIs, dysfunction, perineal laceration. Dan juga menggunakan Boolean Logic. Resiko bias dievaluasi dengan instrumen STROBE (Strengthening of Observational Studies in Epidemiology). Data diolah menggunakan program Rev Manager by Cochrane.

Hasil: Dari hasil penelusuran database secara online didapatkan 28 penelitian. Setelah artikel duplikasi dikeluarkan, dan hanya artikel case-control yang dapat diakses full text berbahasa inggris yang dilibatkan, didapatkan lima penelitian yang dilakukan analisis. Seluruh penelitian menggunakan kuesioner untuk evaluasi dyspareunia, dengan waktu evaluasi yang berbeda ( 3 bulan, 6 bulan, 12 bulan, 25-34 bulan dan 25 tahun). Empat penelitian menggunakan laserasi perineum derajat 1 dan derajat 2 sebagai kelompok kontrol. Sedangkan satu penelitian menggunakan paritas dan tanggal persalinan yang sama sebagai kelompok kontrol. Penelitian ini menunjukkan nilai $\mathrm{p}<0,0001$ didapatkan pada kelompok kontrol.

Kesimpulan: Hasil meta-analisis ini menunjukkan bahwa bahkan pada laserasi perineum derajat satu dan dua (non-OASIs), dyspareunia banyak dialami oleh pasien pasca melahirkan.

\section{LAPORAN KASUS SIGMOID VAGINOPLASTI DENGAN PEMASANGAN STOMA PADA KASUS AGENESIS VAGINA DI RSUP DR SARDJITO, YOGYAKARTA}

Ratih Kumalasari ${ }^{1}$, Nuring Pangastuti ${ }^{2}$

Departemen Obstetri dan Ginekologi

Fakultas Kedokteran, Kesehatan Masyarakat, dan Keperawatan, Universitas Gadjah Mada-RSUP DR Sardjito Yogyakarta

Latar Belakang: Agenesis vagina merupakan suatu bentuk kelainan kongenital dimana tidak terbentuknya vagina dengan perkembangan seks sekunder yang normal. Penanganan agenesis vagina melalui teknik operasi vaginoplasti dengan menggunakan segmen usus yaitu bagian sigmoid telah banyak digunakan dan terbukti lebih baik dibandingkan penggunaan segmen usus yang lain sebagai graf. Perlukaan pada rektum dan vesica urinaria dapat menjadi komplikasi saat durante operasi sigmoid vaginoplasti. Apabila terdapat cedera iatrogenik pada rektum, dapat dilakukan tindakan ileostomi protektif dengan pemasangan stoma yang berguna untuk melindungi anastomosis colorectal.

Tujuan: Tulisan ini menggambarkan kasus sigmoid vaginoplasti pada agenesis vagina dimana dilakukan teknik ileostomi protektif dengan pemasangan stoma.

Laporan Kasus: Terdapat 2 pasien pada periode tahun 2012-2019 yang telah dilakukan operasi sigmoid vaginoplasti dengan pemasangan stoma di RSUP DR Sardjito. Pemasangan stoma ini dilakukan sebagai teknik ileostomi protektif, karena saat durante operasi didapatkan cedera rektum iatrogenik. Penyembuhan pasca operasi sigmoid vaginoplasti hingga pasca operasi penutupan stoma pada kedua pasien ini memberikan hasil yang baik. Tidak didapatkan stenosis ataupun striktur vagina pada kedua pasien ini selama follow-up rutin.

Kesimpulan: Teknik operasi sigmoid vaginoplasti sudah banyak digunakan untuk menangani kasus agenesis vagina. Pemasangan stoma sebagai ileostomi protektif dapat digunakan sebagai alternatif pilihan pada operasi sigmoid vaginoplasti karena memberikan luaran yang cukup baik pada pasien.

Kata kunci: agenesis vagina, sigmoid vaginoplasti, ileostomi protektif

\section{LAPORAN KASUS: SEPTUM VAGINA TRANSVERSAL DAN TATALAKASANA OPERATIF (EKSISI SEPTUM DAN AMNION GRAFT)}

Ranti Pratiwi Permatasari, Suskhan Djusaad, Alfa Putri Meutia

\section{Departemen Kandungan dan Kebidanan RSUP Cipto Mangunkusumo, Jakarta}

Septum vagina transversal adalah salah satu tipe anomaly dari mullerian yang menyebabkan obstruksi dan saluran keluar genital. Penyebabnya adalah gagalnya kanalisasi lempeng vagina di titik sinus urogenital saat bertemu dengan duktus mulerian.1,2 Tipe-tipe septum bermacam-macam yaitu berdasarkan tebal septum dan posisi di vagina seperti pada sepertiga distal, medial dan proksimal.1 Septum dapat tebal atau tipis dan tidak jarang ditemukan mikroperforasi.3 Pada laporan kasus ini, kami melaporkan tatalaksana operatif yang berbeda pada septum vagina transversal yaitu dengan eksisi septum dan penggunaan amnion graft. Kasus ini menampilkan pasien remaja dengan amenorea primer dan nyeri siklik, pada pemeriksaan bimanual didapatkan vagina yang pendek dan teraba massa abdomen. Laporan kasus ini mempresentasikan dua pilihan tatalaksana operatif yang berbeda untuk septum vagina transversal yang tebal dan tipis.

Kata kunci: Septum vagina transversal, eksisi septum, amnion graft. 


\section{LAPORAN KASUS SIGMOID VAGINOPLASTI DENGAN PEMASANGAN STOMA PADA KASUS AGENESIS VAGINA DI RSUP DR SARDJITO YOGYAKARTA}

Ratih Kumalasari ${ }^{1}$, Nuring Pangastuti ${ }^{2}$

Departemen Obstetri dan Ginekologi, Fakultas Kedokteran, Kesehatan Masyarakat dan Keperawatan, Universitas Gadjah Mada-RSUP DR Sardjito Yogyakarta

Latar belakang: Agenesis vagina merupakan suatu bentuk kelainan kongenital dimana tidak terbentuknya vagina dengan perkembangan seks sekunder yang normal. Penanganan agenesis vagina melalui teknik operasi vaginoplasti dengan menggunakan segmen usus yaitu bagian sigmoid telah banyak digunakan dan terbukti lebih baik dibandingkan penggunaan segmen usus yang lain sebagai graf. Perlukaan pada rektum dan vesica urinaria dapat menjadi komplikasi saat durante operasi sigmoid vaginoplasti. Apabila terdapat cedera iatrogenik pada rektum, dapat dilakukan tindakan ileostomi protektif dengan pemasangan stoma yang berguna untuk melindungi anastomosis colorectal.

Tujuan: Tulisan ini menggambarkan kasus sigmoid vaginoplasti pada agenesis vagina dimana dilakukan teknik ileostomi protektif dengan pemasangan stoma.

Laporan Kasus: Terdapat 2 pasien pada periode tahun 2012-2019 yang telah dilakukan operasi sigmoid vaginoplasti dengan pemasangan stoma di RSUP DR Sardjito. Pemasangan stoma ini dilakukan sebagai teknik ileostomi protektif, karena saat durante operasi didapatkan cedera rektum iatrogenik. Penyembuhan pasca operasi sigmoid vaginoplasti hingga pasca operasi penutupan stoma pada kedua pasien ini memberikan hasil yang baik. Tidak didapatkan stenosis ataupun striktur vagina pada kedua pasien ini selama follow-up rutin.

Kesimpulan: Teknik operasi sigmoid vaginoplasti sudah banyak digunakan untuk menangani kasus agenesis vagina. Pemasangan stoma sebagai ileostomi protektif dapat digunakan sebagai alternatif pilihan pada operasi sigmoid vaginoplasti karena memberikan luaran yang cukup baik pada pasien.

Kata kunci: Agenesis vagina, sigmoid vaginoplasti, ileostomi protektif.
Nenny Yoanitha

Departemen Obstetri Dan Ginekologi FK Universitas Padjadjaran Bandung

Latar belakang: Penurunan kekuatan otot levator ani dianggap mendasari secara primer terjadinya prolapsus uteri pada wanita usia lanjut. Secara umum pada usia menopause akan terjadi kelemahan seluruh otot tubuh. Manajemen yang terfokus pada tindakan operatif ternyata memiliki kelemahan yaitu dengan angka rekurensi pasca rekonstruksi yang cukup tinggi, sehingga diperlukan upaya pencegahan progresifitas dan rekurensinya. Vitamin D diduga memiliki peran dalam fungsi fisiologi otot lurik melalui proses regenerasi otot. Berdasarkan hal tersebut maka perlu dilakukan penelitian apakah suplementasi vitamin D sebelum dilakukan operasi rekonstruksi berpengaruh terhadap kekuatan kontraksi levator ani.

Tujuan: Melihat perbedaan kekuatan kontraksi otot levator ani setelah suplementasi vitamin D3, dengan demikian diharapkan pemberian vitamin ini dapat mengurangi insidensi rekurensi prolapsus uteri pasca operasi rekonstruksi.

Metode: Penelitian ini merupakan penelitian eksperimental quasi dengan rancangan sebelum dan sesudah pemberian vitamin D3 pada pasien prolapsus uteri. Subjek penelitian adalah pasien prolapsus uteri yang memenuhi kriteria inklusi penelitian $(n=19)$. Dilakukan pemeriksaan kadar vitamin D serum, pengukuran kekuatan otot levator ani (perineometer peritronTM) dan otot lurik gastrocnemius soleus (hand held dynamometer) sebagai otot pembanding sebelum dan sesudah pemberian 3 bulan vitamin D3. Penelitian dilakukan di Poliklinik Ginekologi FKUP/RSHS, Poliklinik Kedokteran Fisik dan Rehabilitasi FKUP /RSHS dan Laboratorium serologi Klinik Patologi Klinik FKUP/RSHS pada bulan Januari - April 2019

Hasil: Terdapat peningkatan kekuatan kontraksi otot levator ani dengan nilai $\mathrm{p}<0,001$, dan peningkatan kekuatan kontraksi otot gastrocnemius soleus dengan nilai $\mathrm{p}<0,001$ setelah subjek mendapatkan suplemen vitamin D3.

Kesimpulan: Suplementasi vitamin D3 dapat meningkatkan kekuatan kontraksi otot levator ani dan otot gastrocnemius soleus pada penderita prolapsus uteri.

Kata kunci: vitamin D, prolapsus uteri, kekuatan otot levator ani, kekuatan otot gastrocnemius soleus, hand held dynamometer, perineometer.

\section{PERSALINAN SPONTAN PADA UTERUS BIKORNU DAN SEPTUM VAGINA LONGITUDINAL}


Richo L. Kaesmetan ${ }^{1 *}$, R. Bagus Prakoso ${ }^{1}$, Amir Fauzi $^{2}$

${ }^{1}$ RSUD Sultan Muhammad Jamalludin 1, Kabupaten Kayong Utara, Kalimantan Barat

${ }^{2}$ Departemen Obstetri dan Ginekologi, Universitas Sriwijaya, Palembang, Sumatera Selatan

*Korespondensi: richo_kaesmetan@yahoo.com

Latar belakang: Uterus bikornu adalah kelainan fusi dari duktus Mulleri, mempunyai dinding di dalamnya dan terbagi dua di bagian luarnya. Defek kongenital ini biasanya terjadi antara 6-22 minggu in utero. Anomali ini terjadi pada $1-10 \%$ dari populasi acak, 2-8\% dari populasi wanita infertil, dan 5-30\% dari wanita dengan riwayat keguguran. Insiden abortus spontan dan persalinan prematur $66 \%$. Septum vagina longitudinal terjadi karena defek fusi lateral dan dari absorpsi yang tidak sempurna dari bagian sinus urogenital.

Tujuan: Untuk mengetahui diagnosis dan penanganan pada kasus persalinan spontan dengan uterus bikornu dan septum vagina longitudinal.

Kasus: Seorang perempuan berusia 29 tahun, Gravida 2 Para 1 Abortus 0 dengan usia kehamilan 33 minggu dirujuk ke RSUD dengan pembukaan lengkap. Bayi perempuan dilahirkan spontan pervaginam dengan berat badan 1940 gram. Pada pemeriksaan post partum didapatkan septum vagina longitudinal dan pemeriksaan USG transabdominal dan transvaginal didapatkan gambaran uterus bikornu dengan serviks tunggal dan pada ginjal bilateral normal.

Diskusi: Kehamilan dengan uterus bikornu dapat menyebabkan persalinan prematur ataupun pertumbuhan janin yang terhambat karena ukuran rahim hanya berukuran setengah dari normal. Pada uterus bikornu tidak selalu diperlukan intervensi bedah dan menimbulkan hanya sedikit masalah reproduksi. Pada pasien ini, vagina dengan septum longitudinal tidak menghalangi jalannya persalinan dan juga tidak ditemukan kelainan anorektal dan kelainan ginjal.

Kesimpulan: Kasus ini mengilustrasikan suatu konsepsi spontan dan persalinan spontan dapat terjadi tanpa komplikasi pada pasien dengan uterus bikornu dan septum vagina longitudinal. Bayi yang kecil mungkin menjadi salah satu faktor keberhasilan persalinan ini tanpa komplikasi.

Kata kunci: Persalinan spontan, uterus bikornu, septum vagina longitudinal.

\section{KORELASI ANTARA KADAR (HS-CRP) HIGH SENSITIVITY-C-REACTIVE PROTEIN DAN KADAR BDNF (BRAIN DERIVED NEUROTROPHIC FACTOR) URIN MENOPAUSE DENGAN OVERACTIVE BLADDER}

Roy Christian Bangun, Nutrisia Latjindung, Edy Ardiansyah, M. Fidel Ganis Siregar, Herbert Sihite, M. Rhiza Z Tala, Dwi Faradina

Departemen Obstetri dan Ginekologi, Fakultas Kedokteran Universitas Sumatera Utara, RSUP H. Adam Malik Medan

Latar belakang: Terdapat setidaknya 50-100 juta pasien overactive bladder diseluruh dunia dan wanita menopause memiliki risiko lebih tinggi terkena overactive bladder. Overactive bladder lebih rentan pada wanita dengan kadar C-reactive protein (CRP). Digunakannya Brain Derived Neurothropic Factor (BDNF) penanda lebih spesifik.

Tujuan: Penelitian menilai korelasi antara kadar High-Sensitivity-C-reactive protein(hs-CRP), kadar Brain Derived Neurotrophic Factor (BDNF) urin menopause dengan overactive bladder.

Metode: Penelitian analitik observasional, desain penelitian case control pada wanita paramedis menopause mengalami overactive bladder dan tidak mengalami overactive bladder diRSUP Adam Malik bulan januari 2019. Sampel dengan metode non-probability, teknik consecutive sampling. Anam-nesis menentukan derajat $\mathrm{OAB}$ dengan skor $\mathrm{OAB}$, diukur kadar hs-CRP dan BDNF dilaboratorium terpadu. Data terdistribusi normal digunakan uji korelasi Pearson, data tidak terdistribusi normal digunakan ujikorelasi Spearman.

Hasil: Nilai rerata hs-CRP pasien OAB 1,33 $\pm 0,23$, pasien tanpa $\mathrm{OAB} 0,66 \pm 0,34$. Pasien dengan $\mathrm{OAB}$, nilai rerata $\mathrm{BDNF} 430,87 \pm 73,58$, tanpa $\mathrm{OAB}$ $230,97 \pm 29,88$. Kadar hs-CRP urin pasien OAB adalah $>1,04 \mathrm{mg} / \mathrm{L}$ sebanyak 38 pasien $(100 \%)$, pasien tidak OAB $<1,04 \mathrm{mg} / \mathrm{L}$ sebanyak 37 pasien(97,3\%) dengan $\mathrm{p}=0,001$. Kadar BDNF pasien OAB >305,5 pg/L, 38 pasien $(100 \%)$ dan tidak OAB kadar $>305,5 \mathrm{pg} / \mathrm{L}$ sebanyak 38 pasien $(100 \%)$, nilai $\mathrm{p}=0,001$. Korelasi antara hs-CRP dan BDNF pasien OAB, didapatkan korelasi positif sedang dengan $r=0,525$ dan $p<0,001$. Sedangkan korelasi antara hs-CRP dan BDNF pasien tanpa $\mathrm{OAB}$, didapatkan korelasi tidak signifikan, $\mathrm{r}=0,128$ dan $\mathrm{p}=0,442(\mathrm{p}<0,001)$.

Kesimpulan: Terdapat peningkatan kadarhs-CRP dankadar BDNF urin menopause dengan OAB dibandingkandengan non $\mathrm{OAB}$. Terdapat peningkatan rerataka darhs-CRP dan BDNF urin menopause dengan $\mathrm{OAB}$ dibandingkan non OAB. Terdapat korelasi positif sedang yang signifikan antara kadar hs-CRPdan kadar BDNF urin menopause dengan overactive bladder.

Kata kunci: High sensitivity-C-reactive protein, brain derived neurotrophic factor, overactive bladder, menopause. 


\section{NEOVAGINALISASI DAN ANASTOMOSIS UTEROVAGINA PADA AGENESIS CERVIXDAN VAGINA PROKSIMAL DISERTAI HEMATOMETRA DAN HEMATOKOLPOS DENGAN MENGGUNAKAN MODIFIKASI VAGINAL MOLD}

\author{
Benny Yafet Lalompoh ${ }^{1}$, Kadek Fajar Marta ${ }^{2}$ \\ ${ }^{1}$ PPDS-I Departemen/ KSM Obstetrik dan Ginekologi \\ FK UNUD/RSUP Sanglah, ${ }^{2}$ Divisi Uroginekologi, \\ Departemen/ KSM Obstetrik dan Ginekologi FK \\ UNUD/ RSUP Sanglah
}

Tujuan: Melaporkan kasus neovaginalisasi dan anastomosis uterovagina menggunakan modifikasi vaginal mold sebagai penatalaksanaan agenesis cervix dan vagina proksimal disertai hematometra dan hematokolpos.

Kasus: Pasien perempuan 26 tahun, menikah, rujukan dari Sumba (NTB) ke RSUP Sanglah Denpasar dengan diagnosis agenesis cervix-vagina. Pasien mengeluhkan nyeri perut dan tidak pernah menstruasi. Pada pemeriksaan fisik didapatkan vagina sepanjang 3 $\mathrm{cm}$, tidak tampak adanya portio, teraba bulging mass 5 $\mathrm{cm}$ dari anal kanal kesan hematokolpos. Teraba diskontinuitas pada dinding vagina posterior sampai menembus anus ukuran $\pm 1.5 \mathrm{~cm}$ merupakan fistula rektovagina, dicurigai sebagai komplikasi tindakan evakuasi clot tahun 2016-2018 di RS Sumba. Pada pemeriksaan USG, didapatkan uterus ukuran $7.4 \times 5.3 \times 7.7 \mathrm{~cm}$, tampak massa hipoechoic intrauterin ukuran $1.7 \times 2.6 \mathrm{~cm}$ mengesankan suatu hematometra, tidak tampak cervix dan vagina proksimal. Preoperasi, pasien diberi terapi depoprovera injeksi untuk menangani hematokolpos dan hematometra, kemudian dilakukan tindakan operatif neovaginalisasi dan anastomosis uterovagina lalu dipasang Foley kateter intrauterin dengan modifikasi vaginal mold, serta dilakukan repair fistula rektovagina. Pasca operasi pasien kontrol rutin untuk mengantisipasi kemungkinan terjadinya stenosis vagina.

Diskusi: Kelainan kongenital agenesis vagina baik total atau sebagian terjadi akibat gangguan perkembangan duktus Mulleri dengan kejadian berkisar antara 1 : 4.000-10.000 kelahiran. Etiologi secara pasti belum jelas, beberapa peneliti mengatakan hal ini terjadi karena gangguan pada gen autosomal resesif, gangguan pada transmitted sex-linked autosomal dominant, adanya hormon antimullerian atau pengaruh obat-obatan seperti thalidomide. Penanganan dapat dilakukan dengan metode operatif maupun non-operatif. Pada kasus ini metode operatif dipilih dengan menggunakan teknik modifikasi vaginal mold karena teknik ini lebih mudah dikerjakan dan menggunakan alat sederhana.
Kesimpulan: Neovaginalisasi dan anastomosis uterovagina dengan menggunakan modifikasi vaginal mold pada pasien dengan agenesis cervix dan vagina proksimal merupakan salah satu pilihan tatalaksana dengan teknik yang lebih mudah dikerjakan dengan luaran optimal.

Kata kunci: Neovaginalisasi, agenesis cervixvagina, vaginal mold.

\section{EKSPRESI MATRIKS METALOPROTEINASE-2 (MMP-2) YANG TINGGI PADA LIGAMENTUM SAKROUTERINA SEBAGAI FAKTOR RISIKO TERJADINYA PROLAPS UTERUS DERAJAT III- IV}

Ketut Yoga Mira Pratiwi, I Gede Megaputra, Ketut Suwiyoga, I Made Darmayasa, I Nyoman Bayu Mahendra, I Gede Ngurah Harry Wijaya Surya

\section{Departemen/KSM Obstetrik dan Ginekologi FK UNUD/RSUP Sanglah}

Latar belakang: Prolaps uterus adalah turunnya uterus ke dalam liang vagina atau keluar liang vagina sebagai akibat gagalnya ligmentum penyokong dasar panggul, salah satunya ligamentum sakrouterina. Kekuatan ligamentum sakrouterina ditentukan oleh fibroblast dan matriks ekstraselular. Kekuatan matriks ekstraselular sendiri dipengaruhi oleh regulatorregulator seperti TGF- $\beta$, TSP-1 dan matriks metaloprotease (MMPs). Beragam MMP yang berperan dalam degradasi matriks ekstraselular dimana MMP-2 salah satu diantaranya.

Tujuan: Membuktikan ekspresi MMP-2 yang tinggi pada ligamentum sakrouterina sebagai faktor risiko terjadinya prolaps uterus derajat III-IV.

Metode: Penelitian ini merupakan penelitian observasional dengan metode kasus kontrol. Terdapat 22 kasus prolaps uterus derajat III-IV sebagai kelompok kasus dan 22 kasus non prolaps sebagai kelompok kontrol. Penelitian ini dikerjakan di Rumah Sakit Umum Pusat Sanglah dan Laboratorium Patobiologi Fakultas Kedokteran Hewan Universitas Udayana. Sampel diambil dari ligamentum sakrouterina pasien prolaps uterus derajat III-IV dan non-prolaps uterus yang telah dilakukan histerektomi total. Ekspresi MMP-2 dinilai dengan metode pengecatan immunohistokimia.

Hasil: Ekspresi MMP-2 yang tinggi pada ligamentum sakrouterina meningkatkan kejadian prolaps uterus derajat III - IV sebesar 6,5 kali (Rasio Odds =6,5; Interval Kepercayaan 95\% =1,64-25,76; nilai $\mathrm{p}=0,005$ ).

Kesimpulan: Ekspresi MMP-2 yang tinggi pada ligamentum sakrouterina merupakan faktor risiko terjadinya prolaps uterus derajat III-IV. 
Kata kunci: MMP-2, prolaps uterus derajat III-IV.

\section{HEMATOMA VULVOVAGINAL INFRALEVATOR PASKA PERSALINAN DI RUMAH SAKIT SILOAM BANGKA}

\author{
Maya Okta Lestari, Hendra Susanto
}

\section{Departemen Obstetri dan ginekologi, Rumah Sakit Siloam Bangka}

Latar belakang: Hematoma vulvovaginal paska persalinan merupakan kasus relatif jarang terjadi dan bila tidak di tangani dengan baik dapat meyebabkan morbidtas dan mortalitas.

Tujuan: Menyampaikan satu kasus hematoma vulvovaginal infralevator paska persalinan.

Metoda: Laporan kasus.

Laporan Kasus: Wanita 34 tahun, $\mathrm{G}_{4} \mathrm{P}_{2} \mathrm{~A}_{1}$ hamil 39-40 minggu inpartu kala 1 fase laten datang ke unit emergensi RS Siloam Bangka. Pada proses persalinan, pasien mengalami ruptur perineum grade IIa sehingga dilakukan penjahitan. Selama pemantauan kala IV, pasien tidak ada keluhan kemudian dipindahkan ke ruang perawatan biasa. Kira-kira enam jam paska persalinan, pasien mengeluh nyeri hebat di daerah selangkangan terus-menerus. Akibatnya, pasien mengejan untuk menahan rasa nyeri dan sulit tidur. Pasien tidak mengeluhkan kesulitan berkemih. Pada pemeriksaan didapatkan hematoma vulva kiri dengan diameter kurang lebih $10 \mathrm{~cm}$ x $5 \mathrm{~cm}$ dengan keadaan umum pasien presyok. Diagnosis hematoma vulvovaginal dengan presyok ditegakkan dan direncanakan eksplorasi jahitan perineum di ruang operasi segera. Pada saat jahitan perineum dieksplorasi, tidak ditemukan adanya perdarahan aktif namun ditemukan hematoma ukuran 10x10 cm di dalam rongga perineum lateralis kiri sehingga dilakukan insisi dinding lateral vagina untuk evakuasi hematoma. Didapatkan bekuan darah \pm 600 cc serta tampak robekan otot bulbokavernosus, transversus perinei profunda, pubokoksigeus tidak beraturan dengan perdarahan aktif sehingga dilakukan jahitan figure of eight lapis demi lapis untuk menghentikan perdarahan. Ruang dead space di tampon dengan absorbable hemostatic sponge. Paska operasi, pasien diberikan transfusi 3 kantong darah serta antibiotik broadspectrum. Dua hari masa perawatan, pasien di pulangkan. Evaluasi paska operasi dilakukan berkala, didapatkan luka operasi baik, tidak ada tanda hematoma vulva, dan fungsi berkemih dan buang air besar baik.

Kesimpulan: Hematoma vulvovaginal paska persalinan merupakan kasus relatif jarang terjadi pada bidang obstetri namun dapat menyebabkan morbiditas dan mortalitas pada ibu. Kasus ini mengingatkan staf medis untuk lebih berhati-hati dalam pemantauan ibu paska persalinan. Penanganan dan diagnosa yang cepat bisa mengurangi morbiditas dan mortalitas pasien.

Kata kunci: Hematoma vulvovaginal, paskasalin, infralevator.

\section{AMENORE PRIMER PADA PASIEN KELAINAN UTERUS UNIKORNUS DENGAN AGENESIS SERVIKS DAN ATRESIA VAGINA PROKSIMAL}

Muhamad Husen Ali ${ }^{1 *}$, Josua Hisar Simanjuntak ${ }^{1}$, Harnovin Kuanda ${ }^{2}$, Advent Christianus T. Conterius ${ }^{3}$

${ }^{1}$ Dokter Internsip RSUD dr. T. C. Hillers Maumere, Kabupaten Sikka, NTT, ${ }^{2}$ Puskesmas Waigete, Kabupaten Sikka, NTT, ${ }^{3}$ SMF Obstetri dan Ginekologi, RSUD Dr. T.C. Hillers Maumere, Kabupaten Sikka, NTT

*Korespondensi: muhamadhusenali@gmail.com

Latar belakang: Amenore primer terjadi pada $0,1-2 \%$ wanita usia reproduktif. Sekitar $10 \%$ amenore primer disebabkan oleh kelainan perkembangan duktus Mülleri. Stuktur organ reproduksi yang tidak normal tentu menimbulkan masalah besar bagi pasien seperti gangguan fungsi reproduksi dan fungsi seksual.

Laporan kasus: Wanita 36 tahun datang ke rumah sakit dengan keluhan belum pernah menstruasi. Keluhan disertai nyeri perut bawah yang dirasakan hilang timbul setiap bulan. Payudara dan rambut pubis tumbuh sejak usia 11 tahun. Pada pemeriksaan ginekologi ditemukan blind-ending pada vagina. Hasil ultrasonografi trans abdomen menunjukkan kesan hematokolpos, hematometra, dan hematosalping. Dilakukan total abdominal hysterectomy dan bilateral salpingo-oophorectomy.

Diskusi: Diagnosis dan tatalaksana kasus ini menjadi tantangan tersendiri terutama di daerah terpencil. Modalitas pemeriksaan penunjang yang paling baik dalam penegakkan diagnosis adalah magnetic resonance imaging. Pada kasus ini perlu penanganan multidisiplin ilmu yang mencakup tindakan bedah seperti neovaginoplasti, anastomosis utero-vagina, dan kanalisasi serviks. Namun pada pasien tidak dilakukan karena adanya kendala teknis, serta permintaan pasien yang menolak untuk dirujuk.

Kesimpulan: Amenore primer dan kelainan duktus Mülleri merupakan kasus yang sangat jarang, Keberhasilan managemen kasus ini tergantung pada ketepatan dalam mendiagnosis serta ketersediaan tenaga ahli dan sarana di daerah terpencil. 
Kata kunci: Amenore primer, kelainan duktus Mülleri, atresia vagina, agenesis serviks uterus unikornus.

\section{KEBERHASILAN PENETRASI VAGINA PASCA MODALITAS TERAPI GINEKOLOGIS PADA 374 PASIEN VAGINISMUS}

Robbi Asri Wicaksono

\section{Bagian Obstetri \& Ginekologi Rumah Sakit Ibu Anak Limijati Bandung}

Latar belakang: Vaginismus menurut ICD-10 merupakan penyakit organ reproduksi dan saluran kemih, dengan kode N94.2 yaitu kaku otot dinding vagina yang tidak bisa dikendalikan oleh penderitanya sehingga menyebabkan kendala maupun kegagalan penetrasi. Penanganan fisik vaginismus belum menjadi perhatian, karena selama ini dikelirukan sebagai "penyakit yang bersumber dari pikiran". Dilatasi adalah upaya fisik yang terbukti bisa menghasilkan keberhasilan penetrasi. Pada kasus vaginismus dengan derajat menengah-berat, pasien tidak bisa melakukan dilatasi, sehingga dibutuhkan upaya tertentu agar dilatasi bisa terjadi. Prosedur dilatasi berbantu memadukan proses anestesi, injeksi botulinum toxin, dilatasi progresif, dan supervisi dilatasi, dengan keberhasilan penetrasi yang tinggi.

Tujuan: Memaparkan aspek diagnostik dan penatalaksanaan vaginismus secara ginekologis.

Metode: Studi deskriptif ini merupakan pelayanan pasien vaginismus di RSIA Limijati Bandung, periode Januari 2017-April 2019, berjumlah 374 pasien.

Hasil: Rata-rata usia 30,3 tahun (21-56 tahun). Lama menikah rata-rata 3,97 tahun (1 bulan-25 tahun). Vaginismus primer 366 kasus $(97,8 \%)$, vaginismus sekunder 8 kasus. Penanganan psikis sebelumnya (Psikiater dengan obat penenang) pada 63 kasus. Terdapat 4 kasus yang sebelumnya telah dilakukan tindakan pembedahan pada vagina. Derajat keparahan vaginismus pasien, I (1), II (9), III (67), IV (236), V (61). Terdapat 1 kasus kelainan struktur genitalia yaitu sinekia labia minora. Jumlah prosedur dilatasi berbantu adalah 235. Pada 3 kasus ditemukan kelainan struktur genitalia, yaitu 1 kasus septum transversum $1 / 3$ atas, dan 2 kasus septate hymen. Keberhasilan melakukan dilatasi mandiri pasca prosedur 99,5\%. Keberhasilan pemeriksaan medis melalui vagina $97,7 \%$. Rata-rata keberhasilan penetrasi penis $75,9 \%$ dalam 4,6 minggu. Pasca prosedur dilatasi berbantu, pasien mengalami kehamilan alami pada 55 pasien. Pada 43 kasus pasca prosedur, dilakukan penanganan bersama psikiater untuk menghilangkan hambatan psikis yang masih ada, sehingga hasil yang diharapkan tercapai lebih lancar dan cepat.

Kesimpulan: Upaya diagnostik dan penanganan secara fisik memberikan hasil yang nyata dan segera. Diperlukan penelitian lebih lanjut agar aspek medis vaginismus bisa terungkap lebih banyak.

Kata kunci: Vaginismus, penetrasi vagina, dilatasi.

\section{LAPORAN KASUS: FEMALE GENITAL MUTILATION TIPE IV}

Annisa Ika Nurrahmayanti Syakir ${ }^{1}$, Irwan $^{2}$, Trika Irianta $^{3}$

\section{${ }^{1}$ Mahasiswa Fakultas Kedokteran Universitas Hasanuddin, ${ }^{2}$ Department Obstetri \& Ginekologi RS Bhayangkara Makassar, ${ }^{3}$ Divisi Uro-ginekologi, Department Obstetri \& Ginekologi Fakultas Kedokteran Universitas Hasanuddin, POGI Cabang Makassar}

Latar belakang: Female Genital Mutilation (FGM) atau dikenal dengan sunat pada perempuan, ialah segala jenis tindakan yang melibatkan pemotongan sebagian/seluruh alat kelamin eksternal perempuan, atau perlukaan lain pada alat kelamin perempuan tanpa alasan medis yang mendasarinya. Sekitar 200 juta perempuan di 30 negara diperkirakan telah menjalani praktek FGM. Resolusi PBB tahun 2012 memandang FGM sebagai tindakan kekerasan terhadap perempuan dan anak perempuan. Beberapa upaya telah dilakukan, namun FGM sulit untuk dihilangkan. Hal ini karena pada negara-negara yang menganut FGM memiliki akar sosial yang dalam. FGM melanggar hak asasi manusia dan hak untuk mendapatkan kesehatan yang layak, oleh karena itu kami melaporkan kasus ini.

Tujuan: Melaporkan kasus FGM tipe IV di RS. Bhayangkara Makassar.

Kasus: Seorang perempuan usia 23 tahun datang dengan keluhan tidak dapat berhubungan seksual dengan pasangannya karena vagina yang tertutup. Riwayat pernah dilakukan tindakan tradisional berupa penjahitan pada alat kelamin sewaktu berumur delapan tahun di negara asalnya Somalia. Pasien telah menikah sejak tiga bulan yang lalu dan sejak saat itu tidak dapat berhubungan seksual normal dengan pasangannya karena vagina yang tertutup dan meminta untuk dilakukan pencabutan/perlepasan penjahitan. Pada pemeriksaan ginekologi, tampak labia minora kiri dan kanan menyatu membentuk dinding dan menutup orificium vagina, tampak lubang ukuran sekitar $1 \mathrm{x} 1$ $\mathrm{cm}$ di bagian antero lateral introitus vagina. Pemeriksaan ultrasonografi didapatkan organ reproduksi dalam 
batas normal. Pasien kemudian di diagnosis dengan sinekia labia minora et causa FGM Tipe IV.

Kesimpulan: FGM merupakan tindakan ekstrim terhadap kehidupan perempuan yang berhubungan erat dengan kultur sosial, kesehatan fisik, dan psikologis dan sangat bertentangan dengan hak asasi perempuan. Perlunya sosialisasi pada masyarakat maupun praktisi kesehatan dalam menangani perempuan dengan FGM agar tindakan ini tidak dilakukan.

\section{DYSPAREUNIA DAN OBSTETRICS ANAL SPINCHTER INJURIES (OASIS)}

M. Dimas Abdi Putra ${ }^{*}$, Eighty Mardian Kurniawati ${ }^{2}$, Hari Paraton ${ }^{2}$, Gatut Hardianto ${ }^{2}$, Azami Denas ${ }^{2}$

${ }^{1}$ PPDS-1 Obstetri dan Ginekologi RSUD dr. Soetomo/FK Universitas Airlangga Surabaya ${ }^{2}$ Staf Pengajar Divisi Uroginekologi Dept Obstetri dan Ginekologi RSUD dr. Soetomo/FK Universitas

Airlangga Surabaya

*Korespondensi:m.dimas.ap@gmail.com, $+6285335888046$

Latar belakang: Dyspareunia pasca melahirkan merupakan keluhan yang umum terjadi. Studi retrospektif menunjukkan bahwa derajat laserasi perineum merupakan salah satu independent risk factor untuk terjadinya dyspareunia, yang dapat bertahan hingga enam bulan pasca melahirkan. Beberapa bahkan melakukan abstinensia hingga 14 tahun. Penelitian ini dilakukan untuk menganalisis hubungan antara dyspareunia dengan kasus OASIs.

Tujuan: Melakukan analisis hubungan antara dyspareunia dengan kasus OASIs.

Metode: Melakukan penelusuran database dari Cochrane, PubMed dan Elsevier Sciencedirect dengan jenis penelitian case-control, dapat diakses full text, berbahasa Inggris dengan luaran dyspareunia. Kata kunci menggunakan terminologi yang disepakati oleh MesH (PubMed) seperti dyspareunia, sexual, episiotomy, OASIs, dysfunction, perineal laceration. Dan juga menggunakan Boolean Logic. Resiko bias dievaluasi dengan instrumen STROBE (Strengthening of Observational Studies in Epidemiology). Data diolah menggunakan program Rev Manager by Cochrane.

Hasils: Dari hasil penelusuran database secara online didapatkan 28 penelitian. Setelah artikel duplikasi dikeluarkan, dan hanya artikel case-control yang dapat diakses full text berbahasa inggris yang dilibatkan, didapatkan lima penelitian yang dilakukan analisis. Seluruh penelitian menggunakan kuesioner untuk evaluasi dyspareunia, dengan waktu evaluasi yang berbeda ( 3 bulan, 6 bulan, 12 bulan, 25-34 bulan dan 25 tahun). Empat penelitian menggunakan laserasi perineum derajat 1 dan derajat 2 sebagai kelompok kontrol. Sedangkan satu penelitian menggunakan paritas dan tanggal persalinan yang sama sebagai kelompok kontrol. Penelitian ini menunjukkan nilai $\mathrm{p}<0,0001$ didapatkan pada kelompok kontrol.

Kesimpulan: Hasil meta-analisis ini menunjukkan bahwa bahkan pada laserasi perineum derajat satu dan dua (non-OASIs), dyspareunia banyak dialami oleh pasien pasca melahirkan.

\section{LAPORAN KASUS SEORANG ANAK DENGAN SINDROM MRKH DAN VACTERL}

\section{T. Mirza Iskandar ${ }^{1}$, Erwinanto $^{2}$, Lubena $^{1}$ \\ ${ }^{1}$ Divisi Ginekologi Onkologi, ${ }^{2}$ Divisi Uroginekologi Departemen Obstetri dan Ginekologi, Fakultas Kedokteran Universitas Diponegoro, RSUP dr. Kariadi, Semarang}

Latar belakang: VACTERL (Vetebral Defect, Anal Atresia, Cardiac Defect, Tracheoesophageal Fistula/Atresia, Renal Defect, Limb Defect, amd Limb Defect) dan sindrom Mayer-Rokitansky-Kuster-Hauser merupakan keadaan yang jarang ditemui. Ko-okurensi VACTERL dan sindrom MRKH sangat langka dan belum banyak laporan kasus yang dipublikasikan. Meskipun dengan koreksi bedah yang optimal, pasien dengan kelainan VACTERL memiliki risiko mengalami nyeri punggung, inkontinensia fekal dan gangguan fungsional (anomali ekstremitas). Tantangan medis yang timbul bergantung pada jenis dan tingkat keparahan malformasi yang timbul. Perempuan dengan sindrom MRKH yang tidak dapat hamil dapat memicu stres, gangguan psikologis dan kepercayaan diri. Pelaporan kasus-kasus yang jarang ditemukan sangatlah penting untuk memperluas pengetahuan mengenai etiologi, tatalaksana, dan keluaran pada keadaan tersebut.

Laporan kasus: Kami melaporkan suatu kasus yang jarang terjadi, seorang anak 10 tahun dengan MRKH dan suspek VACTERL, dengan keluhan utama nyeri perut yang berulang setiap bulan dan pasien belum pernah menstruasi. Pasien mengalami perkembangan seksual sekunder normal (tanner 3). Pasien terlahir dengan atresia ani dan menjalani colostomy dan surgical repair pada usia 1 tahun. Pasien juga mengalami inkontinensia urine dan alfi, serta menjalani operasi daerah lumbal usia 3 tahun, kedua tungkai pasien mengalami equinovarus. Hasil pemeriksaan karyotyping normal 46, XX. Problem utama pasien adalah nyeri perut berulang setiap bulan, diputuskan dilakukan pengangkatan uterus. Hasil operasi didapatkan uterus bicornu dengan hematometra. Tidak didapatkan serviks 
dan vagina. Didapatkan bilateral hematosalping dan kista coklat ovarium kanan.

Kesimpulan: Kelainan VACTERL dan sindrom MRKH merupakan kejadian yang langka. Kami telah melaporkan seorang anak usia 10 tahun dengan kelainan tersebut. Pemahaman dan ketelitian klinispenting untuk menegakkan diagnosis. Edukasi dan konseling terhadap pasien dan keluarga sebelum dan selama menjalani terapi sangat penting dilakukan. Bantuan psikologis dan medis akan membantu dalam menangani kasus tersebut terutama berkaitan dengan kehidupan seksual dan reproduksi pasien.

Kata kunci: MRKH, VACTERL, atresia ani.

\section{KARAKTERISTIK PENDERITA SEPTUM VAGINA YANG DILAKUKAN TINDAKAN INSISI SEPTUM DI RSUD DR. SOETOMO SURABAYA TAHUN 2014-2018}

\section{Rizalul Rosyiadi, Gatut Hardianto}

Departemen Obstetri dan Ginekologi Fakultas Kedokteran Universitas Airlangga Surabaya, Indonesia

Latar belakang: Anomali vagina mencakup 10\% dari abnormalitas saluran reproduksi wanita. Anomali vagina dapat diikuti anomali saluran genital dan ekstragenital. Salah satu yang tersering adalah septum vagina. Septum vagina dapat muncul dengan amenore primer, nyeri siklik panggul atau perut. Distensi vagina dapat terjadi karena obstruksi, ditandai dengan nyeri punggung, nyeri buang air besar, atau kesulitan buang air kecil.

Metode: Penelitian ini adalah penelitian retrospektif observasional di RSUD Dr. Soetomo Surabaya, dengan sampel pasien septum vagina yang dirawat dan ditatalaksana dari Januari 2014 hingga Desember 2018. Didapatkan 30 pasien. Data diambil dari rekam medis. Dilakukan penjabaran karakteristik, komplikasi, tindakan yang dilakukan dan keluhan paska operasi.

Hasil: Dari 30 penderita septum vagina, 14 penderita dilakukan tindakan insisi/eksisi dan drainase. Dari 30 pasien tersebut, terbanyak usia $<20$ tahun $(22$ pasien), 20-35 tahun (7 pasien) dan sisanya $>35$ tahun (1 pasien). Mayoritas pasien belum menikah (24 pasien). Terkait riwayat menstruasi, 15 pasien $(50 \%)$ pernah menstruasi dan $15(50 \%)$ lainnya tidak. Penyerta terbanyak adalah hematometra-hematocolpos (12 pasien). Dari 30 pasien semua dilakukan USG, 5 pasien dilakukan MRI. Berdasarkan jenis tindakan, 10 pasien dilakukan insisi-drainase, 8 pasien dilakukan pembuatan neovagina, 4 pasien dilakukan eksisi-drainase, 4 pasien belum dilakukan tindakan. Dari 30 pasien, 9 pasien pernah dilakukan repair. Mayoritas pasien (26 pasien) tidak melaporkan keluhan paska operasi, 3 pasien mengeluhkan nyeri akibat stenosis ulang.

Kesimpulan: Septum vagina merupakan kelainan pada wanita yang ditandai dengan adanya sekat pada vagina. Mayoritas pasien septum vagina di RSUD dr. Soetomo pada periode Januari 2014-Desember 2018 berusia muda dengan sebagian pasien masih mengalami menstruasi. Penyerta terbanyak adalah hematometrahematocolpos. Mayoritas pasien dilakukan insisidrainase. Mayoritas pasien tidak melaporkan keluhan paska operasi.

\section{ANALISIS FAKTOR RESIKO GEJALA PROLAPS ORGAN PANGGUL (POP) PADA PASIEN MENOPAUSE DI POLI GERIATRI RSUD DR. SOETOMO}

\section{Rizqy Rahmatyah ${ }^{1}$, Gatut Hardiyanto ${ }^{2}$, Dwi Susanti ${ }^{3}$ \\ ${ }^{1}$ Mahasiswa 1 Pendidikan Dokter \\ ${ }^{2}$ Staf Pengajar Departemen Obstetri dan Ginekologi \\ Fakultas Kedokteran Universitas Airlangga \\ ${ }^{3}$ Staf Pengajar Departemen Ilmu Kesehatan \\ Masyarakat-Kedokteran Pencegahan Fakultas \\ Kedokteran Universitas Airlangga}

Latar belakang: Prolapse organ panggul (POP) didefinisikan penurunan atau herniasi dari organ panggul yang meliputi uterus (uterine prolaps), ujung vagina (apical vaginal prolaps), vagina anterior (cystocele), atau vagina posterior (rectocele). Pelvic Organ Prolapse Distress Inventory-6 (POPDI-6 merupakan satu bentuk kuisioner guna mengetahui kualitas hidup bagi wanita dengan kelainan otot panggul. Penelitian ini bertujuan untuk mengetahui karakteristik pasien menopause dengan tanda-tanda gejala POP di Poli Geriatri RSUD Dr. Soetomo.

Metode: Penelitian ini adalah penelitian analitik observasional dengan metode cross-sectional menggunakan teknik pusposive sampling. Penelitian dilakukan pada Agustus 2016. Populasi dalam penelitian ini adalah pasien Poli Geriatri RSUD Dr. Soetomo. Kuesioner digunakan untuk mengumpulkan data. SPSS digunakan untuk mendapatkan analisa data.

Hasil: Terdapat 56 pasien yang menjadi subyek pada penelitian ini. Data dianalisis dengan uji chisquare, mann-whitney dan uji korelasi Spearman's rho menggunakan SPSS 21.0. Didapatkan 13 responden (23.2\%) yang memiliki gejala POP berdasar POPDI-6, namun dengan hasil skor tertinggi hanya 45.8 (cut-off 75). Korelasi signifikan didapatkan pada hubungan usia awal menopause dengan gejala berkemih tidak tuntas $(\mathrm{p}=0.036)$. 
Kesimpulan: Tidak terdapat hubungan signifikan antara gejala POP dengan variable yag diteliti (usia, lama menopause, jumlah paritas, riwayat persalinan pervaginam), namun terapat hubungan signifikan dengan usia awal menopause dan merupakan factor resiko gejala tonjolan turun dari vagina dan buang air besar tidak lancer pada pasien di Poli Geriatri RSUD Dr Soetomo.

Kata kunci: Prolapse organ panggul, POPDI-6, menopause, geriatri. 